\title{
HIDROFOBICIDADE SUPERFICIAL E COLONIZAÇÃO DE CANDIDA ALBICANS SOBRE RESINA ACRÍLICA TERMOPOLIMERIZÁVEL PARA CONFECÇÃO DE BASES DE PRÓTESES TOTAIS APÓS DESINFECÇÃO EM SOLUÇÕES QUÍMICAS
}

\author{
EMILIO JOSÉ TABARÉ RODRÍGUEZ ACOSTA
}

Dissertação apresentada à Faculdade de Odontologia de Bauru, da Universidade de São Paulo, como parte dos requisitos para obtenção do título de Mestre em Reabilitação Oral.

Orientador: Prof. Dr. Vinícius Carvalho Porto

BAURU

2009 


\section{Rodríguez-Acosta, Emilio José Tabaré}

R618h Hidrofobicidade superficial e colonização de Candida albicans sobre resina acrílica termopolimerizável para confecção de bases de próteses totais após desinfecção química. / Emilio José Tabaré Rodríguez Acosta. - Bauru, 2009. 125p. ; il. ; 30 com.

Tese (Mestrado) - Faculdade de Odontologia de Bauru. Universidade de São Paulo.

Orientador - Prof. Dr. Vinícius Carvalho Porto

Autorizo, exclusivamente para fins acadêmicos e científicos, a reprodução total ou parcial desta dissertação/tese, por processos fotocopiadores e/ou meios eletrônicos.

Assinatura do Autor:

Data:

Comitê de Ética da FOB-USP

Protocolo No: 178/2007

Data: 29/02/2008 


\section{Dedicatória}

A Deus, quem sempre me acompanha no meu caminho e me proporciona as forças e a saúde necessárias para alcançar as minhas metas. Sem dúvidas, minha passagem pelo Brasil foi mais uma das Tuas obras na minha vida. Obrigado mais uma vez, meu Deus!.

Aos meus pais, Tabaré Rodríguez e Mirtha Acosta, por sempre apoiarem cada um dos meus projetos. Vocês representam o meu maior orgulho e exemplo de honestidade, responsabilidade e dedicação ao trabalho. Agradeço a confiança que depositam em mim e por permitir me afastar por estes últimos 4 anos. Agradeço o grande carinho que apesar da distância continuei sentindo. Sem vocês, nada do que hoje eu tenho, seria possível.

Aos meus irmãos, Cindy e José Tabaré Rodríguez Acosta e José Tabaré e Stephanie Rodríguez Vivoní, obrigado pelos momentos, companhia e carinho; vocês representam mais um pilar na minha vida.

Às minhas avós, Irma Inoa e Francisca Arté, por sempre demonstrar o amor imenso que sentem por mim, por me apoiar e incentivar sempre!. 


\section{Agradecimentos especiais}

Ao meu orientador, Prof. Dr. Vinícius Carvalho Porto, por sempre estar disposto a me ajudar, por me apoiar desde os meus começos na FOB-USP, pelo compromisso e dedicação com o meu trabalho. Você sem dúvidas será um dos meus exemplos a seguir de capacidade e dedicação na minha nova carreira como docente. Agradeço mais uma vez os seus conselhos e a sua paciência às vezes que as coisas não saíram como era esperado.

Ao Prof. Dr. Luiz Fernando Pegoraro, quem com entusiasmo, paciência e disposição me ensinou parte do seu infinito conhecimento sobre Reabilitação Oral. Agradeço pelos “puxões de orelha” às vezes que precisei e pelo que aprendi ao seu lado. Muito obrigado Professor!, Hoje eu posso afirmar que minha passagem pelo Brasil simplesmente valeu em parte pelos conhecimentos que o senhor me transmitiu.

À Prof ${ }^{a}$. Dra . Denise Madalena Spolidorio, da Faculdade de Odontologia de Araraquara (FOAR-UNESP), quem se disponibilizou desinteressadamente a cooperar com este trabalho. Agradeço a sua gentileza e disposição em ajudar, não poupando o seu tempo para nos receber na sua sala, esclarecer dúvidas e discutir a metodologia deste trabalho.

Às pessoas que não pouparam esforço e tempo para cooperar com este trabalho: Patrícia Faria, Thais Gasparoto, Marcelo Milanda, Érika Kuriki e Camila Medina . Não tenho como retribuir toda a ajuda dispensada, e, sinceramente, agradeço pela boa vontade e compreensão. Em especial ao meu grande amigo soteropolitano, Matheus Jacobina, pela sua amizade sincera e desinteressada. Muito Obrigado meu amigo, desejo sucesso no seu caminho! 


\section{Agradecimentos}

À Manuela Almonte e Gustavo Godoi, por representar minha família aqui no Brasil, por permitirem fazer parte das suas vidas, pelo carinho e por sempre me apoiar quando precisei. Sempre levarei vocês dentro de minhas melhores lembranças.

Aos meus companheiros de turma de mestrado, Cíntia Lumi, Priscila Brenner, Aline Dantas, Oswaldo Alarcón, David Garcia, Daniel Hiramatsu, Jõao Paulo Cenizo, Fábio Lorenzoni, Fábio Shiratori, Jose Luiz Góes, Felipe Ferreira, Carol Morandini, Roberta Domingues, Marcelo Ramos, Marcos Rodrigues, Gustavo Pimentel, pela convivência e por compartilharmos juntos o caminho até um sonho feito realidade. Em especial a Rosalyn Chidiak, pela sua amizade sincera e cordialidade.

Aos companheiros de grupo de pesquisa Flora Távora, Paulo Mauricio da Silva e Letícia Zarpelão, pela convivência em um ambiente de respeito e cooperação, pelas úteis conversas para esclarecer metodologias. Em especial à Luciana de Rezende, pela compreensão e ajuda desinteressada quando precisei e por demonstrar responsabilidade e dedicação para com o seu trabalho; muito obrigado Lú!

À Faculdade de Odontologia de Bauru (FOB-USP), seu diretor Luiz Fernando Pegoraro. À Comissão de Pós Graduação, representada na pessoa da Prof ${ }^{\mathbf{a}}$. Dra. Maria Aparecida Machado. Às funcionarias da Secretaria da Pós Graduação, em especial à Maria Margareth Mokarzel pela sua disposição e empenho em me ajudar, por oferecer o melhor serviço possível.

Às funcionarias de Clínica de Pós Graduação, Cleusa Leite e Hebe Pereira, por viabilizar o trabalho na clínica e dedicação ao trabalho.

Aos funcionários do CIP I (Centro Integrado de Pesquisa) da FOB-USP, Dona Neusa e Márcia Graeff, pela amabilidade e por sempre se dispor a cooperar comigo.

Aos professores do Departamento de Prótese Dentária da FOB-USP, Prof. Dr. Paulo Martins Ferreira, Prof. Dr. Gerson Bonfante, Prof. Dr. Jose Henrique Rubo, 
Prof. Dr. Wellington Bonachella, Prof. Dr. Milton Salvador, Prof. Dr. Carlos Araujo, Prof. Dr. Paulo César Conti, Prof. Dr. Luiz Fernando Pegoraro, Prof ${ }^{\text {a }}$. Dra ${ }^{a}$ Lucimar Falavinha, Prof ${ }^{a}$. Dra . Karin Hermana Neppelenbroek, Prof. Dr. Pedro César Garcia e o Prof. Dr. Acáccio Lins do Valle, pelos ensinamentos transmitidos.

Aos funcionários da Biblioteca "Prof. Dr Antônio Gabriel Atta"- FOB-USP, pela disponibilidade e ajuda dispensadas.

Aos funcionários do Departamento de Prótese Dentária, Débora Blasca, Ana Cláudia Mattar, Marcelo Giatti, Reivanildo Viana e Valquiria Nogueira. Pela atenção e disposição.

À Prof ${ }^{a}$. Dra . Vanessa Soares Lara, do Departamento de Patologia FOB-USP, pela sua compreensão e por disponibilizar o uso da sua sala. Pela confiança depositada em mim para a realização dos experimentos.

Ao Grupo de jovens de Nossa Senhora Desatadora dos Nós, Maria Emília Soares, Gabriel Pedroso, Renato Minutti, Lucas Coneglian, Daniela Coneglian, Letícia de Oliveira, Padre Gustavo e, em especial, à Tia Edna e Tio Danilo, por formar parte dos meus melhores momentos vividos em Bauru, por fortalecer a minha Fé em Deus e Nossa Senhora, por ser mais que um exemplo de família baseada em princípios e Fé. Por simplesmente mudar a minha vida!. Muito Obrigado!.

Aos meus amigos Christiano Oliveira e Clarissa Telles, por formar parte de minha vida aqui em Bauru, por sempre estar disponíveis quando precisei, pelos momentos de alegria compartilhados, por fazer os meus dias menos estressantes. Muito Obrigado!

Ao meu grande amigo Mauricio Beltrán, obrigado pela a sua amizade sincera e incondicional. 
Aos meus novos amigos, Max Laurent, Milena e Vitor Guarçoni. Embora vocês tenham chegado há pouco tempo, saibam que já formam parte das pessoas pelas quais sempre guardarei estima e consideração.

À minha "Tia" Leslie Casas, por formar parte dos meus amigos, por sempre estar presente!

À Prof ${ }^{a}$. Dr ${ }^{\mathrm{a}}$. Ana Capelozza, do Departamento de Estomatologia FOB-USP, por sempre estar presente, pelo carinho e afeto, por disponibilizar sua ajuda quando tenho precisado. Muito obrigado professora!

Aos funcionários da Urgência Odontológica, obrigado pela boa convivência!

À minha paciente de Clínica de Pós Graduação, Dona Izide Casatti, pela confiança demonstrada, pela paciência quando tinham que ser repetidos alguns procedimentos, pelo tempo esperado; simplesmente por me permitir aprender com o seu caso. Muito Obrigado Dona Izide, sempre me lembrarei da sua alegria característica e de você com muito carinho!

Às minhas primas Karla Jaquez e Georgina Peña, por sempre apoiar meus projetos, por me dar ânimo para continuar, por sempre estar dispostas a ajudar.

À Família Ferreira Oliveira, por sempre me oferecer apoio e carinho!

À CNPq pela concessão da bolsa PEC-Pg, que contribuiu financeiramente com a realização deste trabalho. Por apoiar a formação de profissionais capacitados em paises em desenvolvimento.

À todos os que, ao longo deste período fizeram parte da minha vida. 



\title{
SUMÁRIO
}

\author{
LISTA DE FIGURAS \\ LISTA DE TABELAS \\ LISTA DE GRÁFICOS \\ LISTA DE ABREVIATURAS E SÍMBOLOS \\ RESUMO \\ ABSTRACT
}

1. INTRODUÇÃO E SÍNTESE BIBLIOGRÁFICA ...............................................2

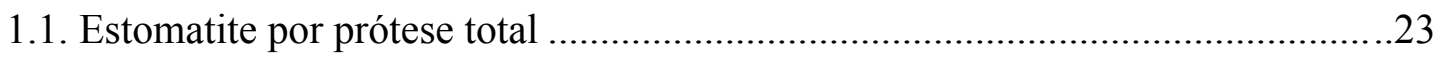

1.2. Fatores relacionados a aderência da $C$. albicans a superfícies de dentes e

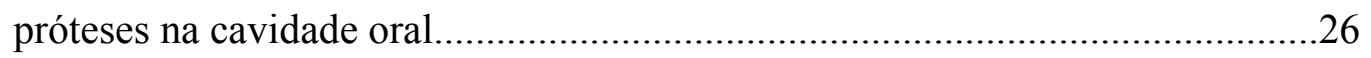

1.3. Aderência da C. albicans: fatores relacionados a leveduras ...............................28

1.3.1 Características e estrutura das parede celular...............................................28

1.4. Adesão da C. albicans a estruturas poliméricas: efeito da

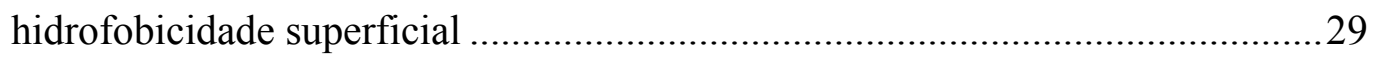

1.5 Película adquirida salivar: efeito na adesão de C. albicans ................................31

1.6 Controle microbiano sobre as próteses totais ...................................................... 34

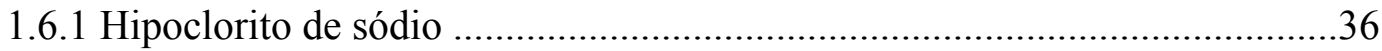

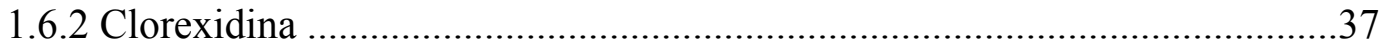

1.6.3 Efetividade do Hipoclorito de sódio e Gluconato de clorexidina ................39

2. PROPOSIÇÃO

3.1. Experimento I: Hidrofobicidade superficial de Resina acrílica termopolimerizável apos desinfecção em soluções químicas.

3.1.1. Confecção e inclusão dos padrões de silicona..............................................47

3.1.2 Manipulação, inserção e termopolimerização da resina acrílica ...................49

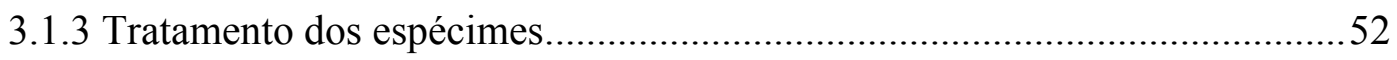

3.1.4. Desinfecção em soluções químicas ...........................................................53

3.1.5. Formação da película adquirida salivar........................................................55 
3.1.6. Medição do ângulo de contato.

3.2. Experimento II: Colonização de C. albicans sobre resina acrílica termopolimerizável apos desinfecção em soluções químicas .....................................58

3.2.1 Confecção e inclusão dos padrões de silicona...............................................58

3.2.2 Manipulação, inserção e termopolimerização da resina acrílica...................60

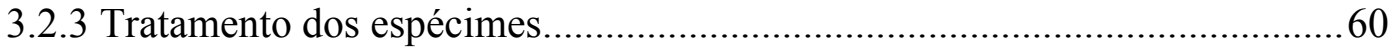

3.2.4. Desinfecção em soluções químicas .............................................................63

3.2.5. Formação da película adquirida salivar.....................................................65

3.2.6 Fase de adesão de C. albicans ...................................................................65

3.2.7 Processamento dos espécimes para microscopia fluorescente .....................67

3.2.8 Análise dos espécimes no microscópio fluorescente....................................68

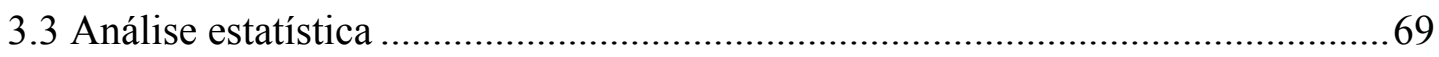

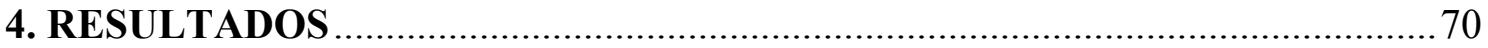

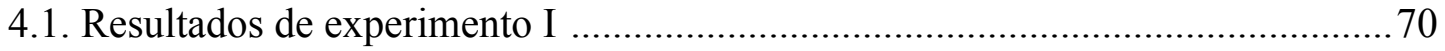

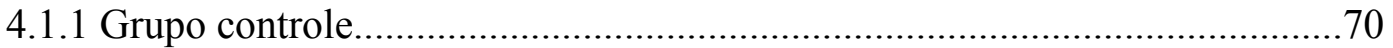

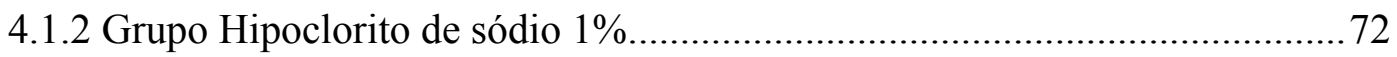

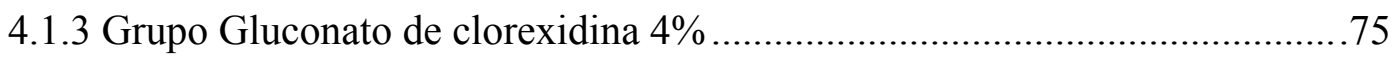

4.1.4 Comparação dos desinfetantes prévios à formação da película adquirida

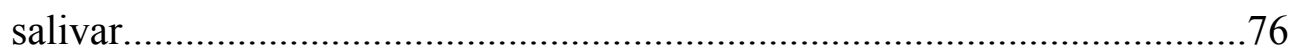

4.1.5 Comparação dos desinfetantes posterior à formação da película adquirida

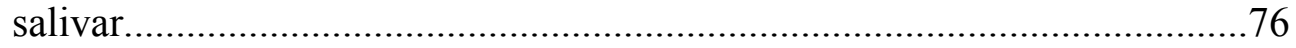

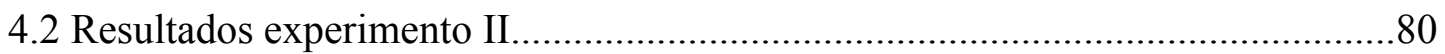

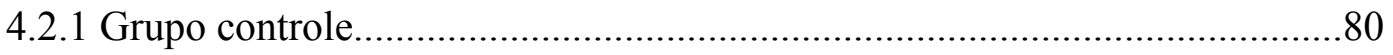

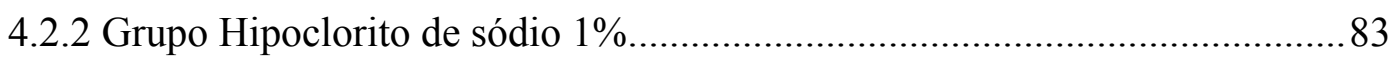

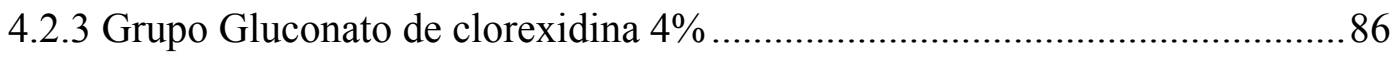

4.2.4 Comparação dos desinfetantes prévios à formação da película

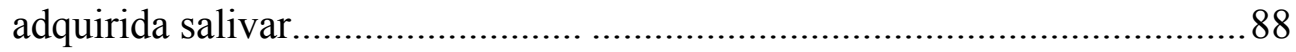

4.2.5 Comparação dos desinfetantes posterior à formação da película adquirida salivar.

4.3 Correlação entre a hidrofobicidade superficial e adesão de C. albicans a resina acrílica termopolimerizável pré e pós formação de película adquirida salivar ...91 


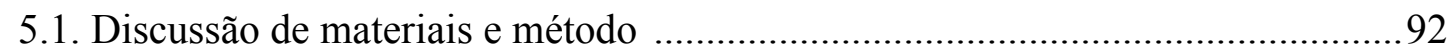

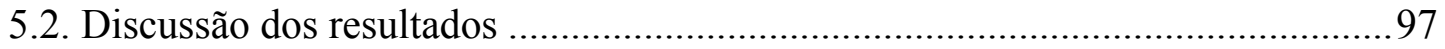

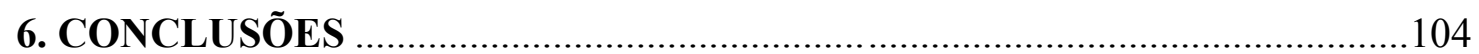

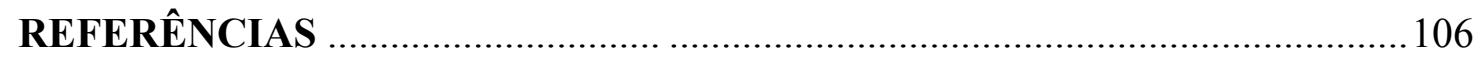

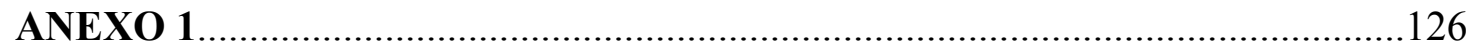




\section{LISTA DE FIGURAS}

\section{Experimento I}

FIGURA 1 - Confecção dos padrões de silicona

FIGURA 2 - Inclusão dos padrões de silicona

FIGURA 3 - Manipulação, inserção e termopolimerização da resina acrílica.

FIGURA 4 - Padronização de rugosidade superficial

FIGURA 5 - Etapas para desinfecção química

FIGURA 6 - Obtenção e clarificação da Saliva. 56

FIGURA 7 - Formação de película adquirida salivar. 56

FIGURA 8 - Técnica de mensuração do ângulo de contato .56

\section{Experimento II}

FIGURA 9 - Confecção dos padrões de silicona

FIGURA 10 - Inclusão dos padrões de silicona

FIGURA 11 - Manipulação, inserção, termopolimerização da resina acrílica e acabamento do pré-especime. 60

FIGURA 12 - Corte dos pré-espécimes, padronização da rugosidade superficial e obtenção dos espécimes

FIGURA 13 - Etapas para desinfecção química .64 
FIGURA 14 -Formação de película adquirida salivar .65

FIGURA 15- Fase de adesão de C. albicans e coloração com laranja de acridina .66

FIGURA 16 Visualização no microscópio de fluorescência. .68

FIGURA 17 - Seqüência padrão do analise de campos .68

FIGURA 18 - Plataforma de trabalho do programa image J 1.38X .69

FIGURA 19 - Mensuração de ângulo de contato do grupo controle, inicial, pré e pos película adquirida salivar.

FIGURA 20- Mensuração de ângulo de contato do grupo Hipoclorito de sódio $1 \%$, inicial, pré e pos película adquirida salivar. .73

FIGURA 21 Mensuração de ângulo de contato do grupo Gluconato de clorexidina 4\%, inicial, pré e pos película adquirida salivar. .75

FIGURA 22 - Imagens de microscopia dos campos do grupo controle, inicial, pré e pos película adquirida salivar. .81

FIGURA 23 - Imagens de microscopia dos campos do grupo Hipoclorito de sódio 1\%, inicial, pré e pos película adquirida salivar.

FIGURA 24 - Imagens de microscopia dos campos do grupo Gluconato de clorexidina $4 \%$, inicial, pré e pos película adquirida salivar. .87 


\section{LISTA DE TABELAS}

TABELA 1 - Divisão dos grupos do experimento I

TABELA 2 - Divisão dos grupos do experimento II

TABELA 3 - Media e desvio padrão dos valores de ângulo de contato de cada grupo, nos diferentes ciclos, prévio a formação de película adquirida salivar ...71

TABELA 4 - Media e desvio padrão dos valores de ângulo de contato de cada grupo, nos diferentes ciclos, posterior a formação de película adquirida salivar..74

TABELA 5 - Media e desvio padrão dos valores de ângulo de contato de cada grupo nos diferentes ciclos, prévio e posterior a formação de película adquirida salivar .77

TABELA 6 - Media e desvio padrão dos valores de células aderidas de C. albicans em cada grupo, nos diferentes ciclos, prévio a formação de película adquirida salivar.

TABELA 7 - Media e desvio padrão dos valores de células aderidas de C. albicans em cada grupo, nos diferentes ciclos, posterior a formação de película adquirida salivar.

TABELA 8 - Media e desvio padrão dos valores de células aderidas de C. albicans em cada grupo, nos diferentes ciclos, prévio e posterior a formação de película adquirida salivar. .88

TABELA 9 - Valor de "p" do teste de correlação entre a hidrofobicidade superficial e adesão de C. albicans. 


\section{LISTA DE GRÁFICOS}

Gráfico 1 - Media e desvio padrão dos valores de ângulo de contato de cada grupo, nos diferentes ciclos, prévio a formação de película adquirida salivar.

Gráfico 2 - Media e desvio padrão dos valores de ângulo de contato de cada grupo, nos diferentes ciclos, posterior a formação de película adquirida salivar. .74

Gráfico 3 - Media e desvio padrão dos valores de ângulo de contato do grupo controle nos diferentes ciclos, prévio e posterior a formação de película adquirida salivar.

Gráfico 4 - Media e desvio padrão dos valores de ângulo de contato do grupo Hipoclorito de sódio $1 \%$, nos diferentes ciclos, prévio e posterior a formação de película adquirida salivar .78

Gráfico 5 - Media e desvio padrão dos valores de ângulo de contato do grupo Gluconato de clorexidina $4 \%$, nos diferentes ciclos, prévio e posterior a formação de película adquirida salivar.

Gráfico 6 - Media e desvio padrão dos valores de células aderidas de C. albicans em cada grupo, nos diferentes ciclos, prévio a formação de película adquirida salivar.

Gráfico 7 - Media e desvio padrão dos valores de células aderidas de C. albicans em cada grupo, nos diferentes ciclos, posterior a formação de película adquirida salivar.

Gráfico 8 - Media e desvio padrão dos valores de células aderidas de C. albicans no grupo controle , nos diferentes ciclos, prévio e posterior a formação de película adquirida salivar 
Gráfico 9 - Media e desvio padrão dos valores de células aderidas de C. albicans no grupo Hipoclorito de sódio 1\%, nos diferentes ciclos, prévio e posterior a formação de película adquirida salivar.

Gráfico 10 - Media e desvio padrão dos valores de células aderidas de C. albicans no grupo Gluconato de clorexidina 4\%, nos diferentes ciclos, prévio e posterior a formação de película adquirida salivar. .90 


\section{LISTA DE ABREVIATURAS E SÍMBOLOS}

$\%=$ Porcentagem

$\mathrm{mm}=$ Milímetro

PMMA $=$ Polimetilmetacrilato

$\mathrm{EP}=$ Estomatite por prótese total

$s p=$ Espécie

$\mu \mathrm{m}=$ Micrometro

DLVO = Teoria DLVO - Derjaguin, Landau, Verwey e Overbeek

ELS $=$ Energia livre de superfície

$\mathrm{nm}=$ Nanômetros

$\mathrm{G}_{\text {tot }}=$ Energia gibbs total

C. albicans $=$ Candida albicans

C.tropicallis $=$ Candida tropicallis

C. glabrata $=$ Candida glabrata

C. krusei $=$ Candida Krusei

C. stellatoidea $=$ Candida stellatoidea

C. parapsilosis $=$ Candida parapsilosis

E. Faecalis = Enterococos Faecalis

P. Aeruginosa $=$ Pseudomonas aeruginosa

E. Coli $=$ Escherichia coli

E. Auerus $=$ Estafilococos aureus

PTFE $=$ Politetrafluoretileno

Erg. $\mathrm{cm}^{-2}=$ Ergômetros por centímetro

$\mathbf{o}=$ Graus

HOCL $=$ Ácido hipocloroso

OCL = Íons de hipoclorito

$\mathrm{pH}=$ Potencial hidrogeniônico

$\mathrm{w} / \mathrm{w}=$ Porcentagem peso/peso

$\mathrm{v} / \mathrm{v}=$ Porcentagem volume/volume

$\mathrm{kg}=$ Kilograma 
$\operatorname{kgf}=$ Kilograma-força

HeLa = Célula extraída de câncer cervical de paciente Henrietta Lacks,

$\mathrm{g}=$ Grama

$\mathrm{ml}=$ Mililitro

${ }^{\circ} \mathrm{C}=$ Graus centígrados

$\mathrm{UV}=$ Ultra violeta

$\mathrm{rpm}=$ Rotações por minuto

$\mathrm{Ra}=$ Unidade de medida de rugosidade superficial

$\mathrm{p}=$ Nível de significância

$\mathrm{W}=$ Watts de potência

$\mathrm{H} 1 \%=$ Grupo hipoclorito de sódio à $1 \%$

GC4\% = Grupo gluconato de clorexidina à $4 \%$ 


\section{RESUMO}

\section{Hidrofobicidade superficial e colonização de Candida albicans sobre resina acrílica termopolimerizável para confecção de bases de próteses totais após desinfecção química.}

A utilização de soluções químicas para desinfecção de próteses totais constitui atualmente uma das opções para a manutenção da limpeza e saúde na cavidade oral de pacientes portadores de dentaduras. O objetivo deste estudo foi avaliar o efeito de duas soluções desinfetantes (Hipoclorito de sódio 1\% e Gluconato de clorexidina 4\%), na hidrofobicidade superficial e adesão de Candida albicans ATTC 90028 sobre resina acrílica termopolimerizável, inicialmente e após 1, 7, 15 e 30 ciclos de desinfecção química, além de verificar o efeito da formação da película adquirida salivar sobre as duas variáveis avaliadas através de mensuração de ângulo de contato e microscopia de fluorescência. Para a mensuração da hidrofobicidade superficial 18 espécimes ( 10 x 25 x $2 \mathrm{~mm}$ ) foram confeccionados em resina acrílica termopolimerizável e desinfetados, simulando a implementação de um protocolo de desinfecção diária durante 30 dias. Após completar o número de desinfecções de cada um dos períodos avaliados, mensurações de ângulo de contato foram feitas antes e depois da formação da película adquirida salivar. Para os testes de adesão de C. albicans à resina acrílica termopolimerizável, 180 espécimes $(5 \times 5 \times 1 \mathrm{~mm})$ foram confeccionados em resina acrílica termopolimerizável e desinfetados e divididos em vários períodos (Inicial-1-7-15-30 ciclos de desinfecção). Após completar o número de desinfecções de cada um dos períodos avaliados, foram feitos ensaios de adesão de C. albicans utilizando o fluorocromo laranja de acridina para posterior visualização mediante o uso de microscópio de fluorescência. Os dados de hidrofobicidade superficial foram analisados através do teste paramétrico ANOVA medidas repetidas e T-Student. Para os resultados de adesão de C. albicans foi utilizado o teste não paramétrico Kruskall Wallis e teste de Dunn. Para correlacionar as variáveis foi utilizado o teste de Pearson. Os resultados obtidos demonstraram que a imersão da resina acrílica em soluções desinfetantes diminui a adesão de C. albicans e os valores de hidrofobicidade superficial em todos os grupos após 30 desinfecções químicas. A formação da película adquirida salivar diminui a adesão de $C$. albicans e hidrofobicidade 
superficial, em todos os grupos após 30 desinfecções químicas. Não existe correlação entre os valores de adesão de C. albicans e hidrofobicidade superficial da resina acrílica termopolimerizável após desinfecção química, exceto para os grupos controle e Gluconato de clorexidina 4\% prévio a formação da película adquirida salivar.

Palavras-chave: Candida albicans. Prótese Total. Hidrofobicidade. Desinfecção. 


\section{ABSTRACT \\ Surface hydrophobicity and Candida albicans colonization on heat-cure acrylic resin for denture base after chemical disinfection.}

The use of chemical solutions for dentures disinfection currently constitutes one of the options for the maintenance of the cleanness and oral health of dentures users. The objective of this study was to evaluate the effect of two disinfecting solutions (Sodium Hypochlorite $1 \%$ and Gluconate chlorhexidine 4\%), on the acrylic resin surface hydrophobicity and adhesion of Candida albicans ATTC 90028 on the heat-cure acrylic resin before and after 1, 7, 15 and 30 chemical disinfectant cycles. Furthermore to verify the effect of the formation of the acquired salivary pellicle on the variables, evaluated through contact angle measurements and fluorescence microscopy. For the surface hydrophobicity assay, 18 specimens $(10 \times 25 \times 2 \mathrm{~mm})$ had been confectioned in heat cure acrylic resin and disinfected, simulating the implementation of a daily dentures chemical disinfection protocol, during 30 days. After each disinfection period, contact angle measurements were made before and after the acquired salivary pellicle formation. For $C$. albicans adhesion assay, 180 specimens $(5 \times 5 \times 1 \mathrm{~mm})$ had been confectioned in heat cure acrylic resin, chemically disinfected and divided in: Initial, 1, 7, 15 and 30 disinfection cycles. After completed each period of chemical disinfection C. albicans adhesion analysis had been made using, fluorocrome acridine orange for posterior visualization by the use of fluorescence microscope. The data of acrylic resin surface hydrophobicity had been analyzed through parametric test ANOVA repeated measures and T-Student. For the C. albicans adherence results, Kruskall Wallis no parametric test and Dunn's test were used. To correlate the variables Pearson test were used. The results had demonstrated that the immersion of the heat cure acrylic resin in disinfecting solutions diminishes the adhesion of $C$. albicans and the values of acrylic resin surface hydrophobicity, in all the groups, in a period of 30 cycles. The formation of the acquired salivary pellicle diminishes the adhesion of $C$. albicans and acrylic surface hydrophobicity in all the groups in a period of 30 cycles. Correlation does not exist 
between the values of $C$. albicans adhesion and acrylic surface hydrophobicity after chemical disinfection, except for the Control group and Gluconate chlorhexidine 4\% group before the formation of the acquired salivary pellicle.

Keywords: Candida albicans. Dentures. Hidrophobicity. Disinfection. 


\section{INTRODUÇÃO E SÍNTESE BIBLIOGRÁFICA}

$\mathrm{Na}$ cavidade oral convivem diversas espécies de microrganismos dentro de um ciclo biológico dinâmico. A maioria destes microrganismos, principalmente os responsáveis pelo aparecimento de processos patológicos, somente podem sobreviver quando conseguem se aderir a superfícies como dentes, mucosa, materiais restauradores, implantes ou próteses dentárias (QUIRYNEN; BOLLEN, 1995). O mecanismo de adesão é controlado por um sistema de equilíbrio presente na cavidade oral, onde diversas forças de remoção microbiana interferem, através da deglutição, fricção pela dieta, língua, higiene oral e a autolimpeza da cavidade oral através dos movimentos mastigatórios, mecanismo denominado de autóclise. (TEUGHELS et al., 2006)

$\mathrm{Na}$ cavidade oral, a substituição do tecido dental por materiais restauradores estabelece condições para que estas superfícies sejam colonizadas por microrganismos; onde entre outros fatores, a exposição à saliva, a topografia da superfície e a composição dos materiais restauradores influenciam na capacidade de adesão dos microorganismos e na velocidade de formação da placa bacteriana. (ÁBALOS, 2005; TEUGHELS et al., 2006).

A perda total dos dentes produz alterações na vida social do individuo e no funcionamento do sistema estomatognático, levando a necessidade da utilização de próteses totais fixas (sobre implantes) ou removíveis. A prótese total removível é o método mais accessível e utilizado para reabilitar pacientes edentados, sendo constituídas por dentes artificiais presos a uma base de polimetilmetacrilato (PMMA), que promove suporte, retenção e estabilidade a esta prótese.

Esta base apresenta uma superfície interna irregular que está em íntimo contato com a mucosa oral e uma superfície externa polida. A superfície interna é de extrema importância para os usuários de dentaduras devido a sua capacidade de atuar como reservatório de microorganismos capazes de desencadear processos patológicos nos tecidos de suporte (BUDTZ-JORGENSEN, 1974; LOCKHART et al., 1999; SUMI et al., 2003), principalmente quando uma técnica efetiva de higiene das dentaduras e da cavidade oral não é habitual. 


\subsection{Estomatite por Prótese Total}

A estomatite por prótese total se destaca na literatura como um dos processos patológicos relacionados aos usuários de prótese total, podendo também ser relatada como estomatite por dentadura ou estomatite protética (BERGENDAL, 1982; BUDTZJORGENSEN; STENDERUP; GRABOWSKI, 1975; CROCKETT; O'GRADY; READE, 1992; GUGGENHEIMER et al., 2000; JEGANATHAN; PAYNE; THEAN, 1997; KREHER et al., 1991; KUC; SAMARANAYAKE; VAN HEYST, 1999; KULAKOZKAN; KAZAZOGLU; ARIKAN, 2002; MCMULLAN-VOGEL et al., 1999; SANTARPIA et al., 1990; SCHOU; WIGHT; CUMMING, 1987; VASILAS et al., 1992), candidíase eritematosa (CROCKETT; O'GRADY; READE, 1992), ferimento por dentadura "denture sore mouth"(BUDTZ-JORGENSEN, 1978; CROCKETT; O'GRADY; READE, 1992); estomatite por dentadura associada a Candida (AXELL et al., 1997; BEAUSEJOUR et al., 1998; CROSS et al., 1998; MAZA et al., 2002; RADFORD; CHALLACOMBE; WALTER, 1999; SAN MILLAN et al., 2000), estomatite induzida por dentadura (BUDTZ-JORGENSEN et al., 2000; CUMMING et al., 1990; EDGERTON; LEVINE, 1992; JENNINGS; MACDONALD, 1990; NIKAWA; HAMADA; YAMAMOTO, 1998; OHMAN et al., 1995), candidose oral associada ao uso de dentadura (BUDTZ-JORGENSEN et al., 2000), candidíase atrófica crônica (BUDTZ-JORGENSEN, 1978; LYNCH, 1994) estomatite relacionada à dentadura(BARBEAU et al., 2003). Devido a essa variedade de nomenclaturas, adotaremos Estomatite por Prótese Total (EP) como único termo no decorrer deste trabalho, por considerarmos o mais adequado, sendo também o mais utilizado e universalmente aceito. (ARENDORF; WALKER, 1987)

A estomatite por Prótese Total é definida como um processo inflamatório da mucosa oral associada à utilização de prótese total removível. Em 1936 esta patologia foi relacionada a infecção por Candida sp. (BARBEAU et al., 2003) e esta relação tem se confirmado em vários outros trabalhos (BUDTZ-JORGENSEN, 1970; CEBALLOS; GONZALEZ-MOLES; URQUIA, 1990; FOTOS; HELLSTEIN, 1992; OLSEN, 1974)

A etiologia da doença é considerada multifatorial, teoria excelentemente explicada por arendorf et al 1987, que relata que a infecção bacteriana, a irritação 
mecânica, o uso continuo da dentadura, a higiene oral deficiente, os fatores associados com a dieta, a reação alérgica aos materiais de confecção da prótese e condições sistêmicas predisponentes podem ser acrescentados a associação de Candida sp. no aparecimento da doença (ARENDORF; WALKER, 1987). Raramente a doença se apresenta sem a presença de pelo menos um fator predisponente que diminua a resistência do indivíduo. (IACOPINO; WATHEN, 1992).

Embora a espécie Candida albicans (C. albicans) seja a mais freqüentemente isolada nos quadros de estomatite (WILLIAMS et al., 1997), podem ser também identificadas outras espécies em menor proporção como a Candida Tropicallis, Candida Glabrata, Candida Krusei, Candida Parapsilosis, Candida Guillermondi e Candida Dubliniensis. (CANNON; CHAFFIN, 1999; FRIDKIN; JARVIS, 1996; SULLIVAN; COLEMAN, 1998). A C. albicans pode ser classificada como um fungo assexual diplóide (RADFORD; CHALLACOMBE; WALTER, 1999) de forma arredondada ou ovalada de 3 a $5 \mu \mathrm{m}$, gram positiva e com metabolismo principalmente aeróbio (UREÑA, 1995). Pode se apresentar na fase de levedura (inócua) ou fase de hifa ou micelial (patogênica) (BUNETEL; BONNAURE-MALLET, 1996; ROGERS; BALISH, 1980). É comumente notada em pacientes portadores de próteses totais, pacientes imunodeprimidos, que se submeteram a antibioticoterapia ou usuários de medicamentos que induzam à xerostomia (BIRMAN, 2002).

Alguns fatores de patogenicidade da C. albicans possibilitam o desenvolvimento de doenças com maior freqüência do que outras espécies de Candida. Primeiramente encontra-se na forma de levedura para dar início a lesão, mas variações nutricionais e ambientais modulam, com o tempo, sua conversão para a fase de hifa, aumentando sua virulência, constituindo um bom mecanismo de escape da atividade fagocítica dos macrófagos (UREÑA, 1995).

A presença da Candida sp é considerada uma condição normal de comensalismo e não necessariamente é indicativo do aparecimento da patologia, pois aproximadamente 40\% de indivíduos em condições saudáveis (RADFORD; CHALLACOMBE; WALTER, 1999) e 75\% de usuários de dentaduras (BUDTZ-JORGENSEN; STENDERUP; GRABOWSKI, 1975) carregam o microorganismo sem apresentar sinais clínicos de inflamação. 
Assim, sua colonização na cavidade oral pode ser definida como a aquisição e manutenção de uma população constante de leveduras que não desencadeiam nenhuma patologia clínica (CANNON; CHAFFIN, 1999). Em condições fisiológicas normais, podem ser encontradas cepas numa média de 300 a 500 células por ml (ARENDORF; WALKER, 1980; CANNON; CHAFFIN, 1999)

A prevalência de estomatite por prótese total tem sido reportada entre 11 a $67 \%$ (ARENDORF; WALKER, 1987). A sua frequência aumenta com a idade (DAVENPORT, 1970). É observada principalmente na mucosa palatina que serve de suporte para as próteses totais (WEBB et al., 1998), sendo rara a sua manifestação no arco mandibular. Tem sido associada a queilite angular, glossite atrófica, candidose pseudomembranosa aguda e candidose hiperplásica crônica. A condição é geralmente assintomática, mas quando sinais e sintomas estão presentes, é relatado sangramento da mucosa, sensação de ardor, sabor desagradável, boca seca e halitose. (ARENDORF; WALKER, 1987)

Existem diversas propostas de diferentes autores (BERGENDAL, 1982; BERGENDAL; ISACSSON, 1983; BUDTZ-JORGENSEN, 1970) para a classificação das diferentes formas de apresentação da estomatite por prótese total. Uma das mais difundidas é a classificação de Newton, (NEWTON, 1962) por ser considerada simples e objetiva. Assim, segundo Newton, a estomatite por prótese total é classificada em 3 tipos:

Tipo I: refere-se ao estagio inicial, onde se apresentam pontos hiperêmicos localizados.

Tipo II: considerada a mais comum dos tipos de estomatite, apresenta-se como um eritema difuso e edema da superfície mucosa. É demarcada pela área marginal da prótese. A condição não é dolorosa e pode se associar a queilite angular.

Tipo III: acredita-se que é desenvolvida a partir de uma estomatite tipo II não tratada por um longo período. Apresenta-se como uma região hiperplásica resultando numa lesão nodular associada a áreas atróficas, referidas como hiperplasia papilar.

O tipo I está relacionado principalmente a traumas localizados, de origem protética, que associado ao acúmulo de placa microbiana (bacteriana ou fúngica) na superfície interna da prótese total e a mucosa subjacente poderia desencadear um quadro 
patológico difuso (Newton II e III) (ARENDORF; WALKER, 1979; BUDTZJORGENSEN, 1974).

\subsection{Fatores relacionados a aderência da $C$. albicans a superfícies de dentes e próteses na cavidade oral.}

Os mecanismos de adesão dos microrganismos na cavidade oral têm sido observados desde épocas passadas, onde diversas características e teorias como a hidrofobicidade (ROSENBERG; KJELLEBERG, 1986), Zeta potencial (OLSSON; GLANTZ; KRASSE, 1976), energia Gibbs, teoria DLVO que descreve a força entre duas superfícies carregadas eletrostaticamente e um liquido interposto; e a energia livre de superfície (ELS) (ABSOLOM et al., 1983); (BUSSCHER, H.; WEERKAMP, 1987) foram relacionadas à adesão de microrganismos a superfícies duras.

É amplamente reconhecido que o primeiro estágio de colonização envolve a adesão do microorganismo à superfície do hospedeiro (DOUGLAS, 1985) e o desenvolvimento dos processos patológicos na cavidade oral são precedidos pela adesão microbiana. Embora não exista uma única teoria definitiva que explique o procedimento fundamental de adesão microbiana nas superfícies orais, (RADFORD; CHALLACOMBE; WALTER, 1999; TEUGHELS et al., 2006) na literatura existe um consenso da existência de 4 fases no processo de adesão:

\section{Fase I: transporte à superfície}

Realizada através de difusão (movimento Browniano) ou movimento ativo (Quimiotaxia).

\section{Fase II: Adesão inicial}

À distância de separação de pelo menos $50 \mathrm{~nm}$, o microorganismo é atraído para a superfície pelas forças de Van der Walls. Mas, se o microorganismo e a superfície apresentarem cargas similares, como geralmente acontece na cavidade oral, ocorrerá uma repulsão devido as forças eletrostáticas repulsivas. As duas forças podem ser totalizadas na energia de interação de Gibbs $\left(\mathrm{G}_{\text {tot }}\right)$ que descreve a total interação a longo alcance, 
quando um microorganismo e a superfície fazem contato e um líquido está interposto entre eles. A força de interação pode ser calculada através da presunção que as interfaces microorganismo/líquido e sólido/liquido serão substituídos pela interface sólido/microorganismo. A mudança em energia livre da adesão é descrita pela fórmula desenvolvida por Absolom (ABSOLOM et al., 1983). Se a mudança da energia livre for negativa, a adesão é termodinamicamente favorável e será realizada espontaneamente, pois naturalmente é preconizada a diminuição da energia livre (modelo termodinâmico de adesão).

\section{Fase III: Adesão}

A membrana celular da C. albicans tem duas funções principais: manter a forma da célula e a interação com o meio externo. Componentes celulares específicos têm sido relacionados a adesão do microorganismo à superfícies hospedeiras. A estrutura da membrana celular é complexa, com pelo menos 5 camadas descritas (CALDERONE, R.A.; BRAUN, 1991).

Os principais polissacarídeos presentes na membrana celular são o glucano e a citina. O maior antígeno é a mannan, que mediante ligações covalentes se unem as proteínas para formar a manoproteina que apresenta ação enzimática e função de receptor, que interagirá com outros receptores presentes nas superfícies a colonizar.

Nesta fase 3 é possível observar a interação da C. albicans com superfícies acrílicas, onde sempre haverá uma camada interposta, denominada película adquirida salivar, com vários graus de maturação.

\section{Fase IV: Colonização}

Nesta fase, os microorganismos crescem e formam placas, denominadas biofilmes. A co-agregação microbiana ocorre nesta fase, já que biofilmes de uma única espécie não ocorrem naturalmente.

Os quatro estágios de adesão microbiana são dependentes de condições como a energia livre de superfície e a rugosidade, mas a rugosidade é considerada como uma característica importante frente a energia livre de superfície na adesão de microorganismos. (QUIRYNEN; BOLLEN, 1995) (TEUGHELS et al., 2006) 
Outros autores afirmam que existem diferentes mecanismos de adesão para diferentes superfícies. É sugestivo que a teoria de adesão não especifica é a mais apropriada para explicar a adesão microbiana a superfícies inertes onde interferem as forças iônicas, hidrofóbicas e de Van der Walls. (BUSSCHER, H.J.; COWAN; VAN DER MEI, 1992)

\subsection{Aderência da $C$. albicans: fatores relacionados às Leveduras}

\subsubsection{Características e estrutura da parede celular}

A adesão entre a célula e a película adquirida salivar formada sobre o substrato é mediada pelas adesinas. A produção de adesina pela célula esta diretamente relacionada com as condições de cultivo da levedura, sendo influenciado pelo alto conteúdo de galactose ou sucrose. (MCCOURTIE; DOUGLAS, 1984). Estas moléculas atuam como receptores para o fibrinogênio, a fibronectina, o colágeno, a $\mathrm{N}$-acetilglucosamina e os peptídeos C3d e iCeb.

O material polimérico extracelular (MPE) também forma parte da parede da levedura e está relacionado à capacidade de adesão das espécies de Candida. O MPE é composto por carboidratos $(65-82 \%)$, proteínas $(7 \%)$, fósforo(0.5\%) e glucosamina $(1.5 \%)$. Sua produção depende do tipo de carboidrato que intervenha no desenvolvimento da célula (MCCOURTIE; DOUGLAS, 1981) e sua presença tem demonstrado o aumento da adesão da Candida a superfícies acrílicas.

A Manose, substância álcali-solúvel presente no interior e superfície mais externa da parede celular da Candida, pode também intervir no processo de adesão. Células de Candida tratadas com ácidos e bases para extração da manose apresentam uma adesão diminuída a células do epitélio bucal em comparação a células não tratadas (CALDERONE, R., 1998; SAN MILLAN et al., 1996).

A Quitina, substância similar a adesina, presente na parede celular, possui um extrato solúvel que inibe a adesão da $C$. albicans a células do epitélio vaginal. Ainda existem dúvidas sobre o verdadeiro efeito da quitina na adesão, devido a esta se encontrar na parede interna da célula (OLSEN, 1990). 
Outros componentes da camada celular que estão associados, de forma direta, com o potencial de adesão da C. albicans são as proteinases e fosfolipases extracelulares. Olsen (OLSEN, 1990) reportou que a existência de lipídeos na membrana celular que parecem estar envolvidos na capacidade de adesão da C. albicans. Lipídeos como a ceramida monohexosido e ceramida dihexosido, assim como o estearil glucosido isolados de hifas, produzem a inibição na adesão do fungo.

\subsection{Adesão da $C$. albicans a estruturas poliméricas: efeito da hidrofobicidade superficial.}

Os diferentes graus de hidrofobicidade da superfície celular de distintas cepas de Candidas estariam relacionadas com uma maior ou menor capacidade das leveduras em se aderir a materiais e bases de próteses. A adesão do fungo também esta associada à energia livre de superfície do material que constitui as dentaduras.(CALDERONE, R., 1998; CANNON; CHAFFIN, 1999; KLOTZ; DRUTZ; ZAJIC, 1985; MINAGI et al., 1985). O primeiro trabalho que fez esta relação, (MINAGI et al., 1985) verificou a associação entre a adesão das espécies C. albicans e C. tropicallis à 21 materiais de base de dentadura, sendo 9 termopolimerizáveis, 2 autopolimerizáveis, 9 materiais de reembasamento macios e uma resina polisulfonada. Os ensaios de adesão foram realizados em superfícies não cobertas por película adquirida salivar. Foram realizados testes de energia livre de superfície mediante a mensuração do ângulo de contato nos materiais testados. Os resultados mostraram que enquanto aumenta a energia livre de superfície, aumenta a adesão de C. albicans, porém diminui a adesão de C. tropicallis.

Diversos autores, (KLOTZ; DRUTZ; ZAJIC, 1985; MINAGI et al., 1985; MIYAKE et al., 1986) asseguraram que as espécies mais hidrofóbicas C.tropicallis, $C$. glabrata e C. krusei aderem-se em maior quantidade a superfícies poliméricas quando comparadas com as espécies menos hidrofóbicas, como C. albicans, C. stellatoidea, $C$. parapsilosis. Samanarayake et al 1995 (SAMARANAYAKE, Y.H. et al., 1995) concluiu que na espécie C. Krusei, (mais hidrofóbica que a C. albicans) existe uma correlação entre a hidrofobicidade e a adesão a células de HeLa (célula de uso laboratorial), o que não se observa na resina acrílica da dentadura. Esses dados sugerem que outros fatores 
contribuem na hierarquia de virulência das espécies da Candida. Em um estudo anterior, concluiu-se que a C. albicans apresentou uma maior adesão frente a outras espécies de Candida à resina acrílica de dentadura (SEGAL; LEHRMAN; DAYAN, 1988).

No que tange a propriedades dos materiais poliméricos, podemos ressaltar a Hidrofobicidade superficial, também denominada por alguns autores de Energia livre de superfície (ELS). A hidrofobicidade superficial está exclusivamente relacionada à reação do sólido frente à água e não a uma gama de líquidos de diferentes tensões superficiais junto a mensuração de ângulos de contato , utilizados normalmente na mensuração da ELS. (COMBE; OWEN; HODGES, 2004). A água é reconhecida pela alta capacidade de união que apresenta, tendo como resultado uma maior afinidade com materiais que apresentam características de hidrofílicidade e consequentemente uma ELS alta. Geralmente a hidrofobicidade diminui quando a ELS aumenta. Superfícies hidrofílicas, como o vidro, apresentam ELS alta, enquanto que superfícies hidrofóbicas, como o Politetrafluoretileno (PTFE), apresentam uma ELS baixa. (DARVELL)

Por este trabalho utilizar como único liquido de mensuração a água, proposta na equação de Neumann (NEUMANN et al., 1974), o termo adotado foi de hidrofobicidade superficial e os resultados expressados em ângulo de contato. Não são reportados dados de componentes polares e de dispersão em erg. $\mathrm{cm}^{-2}$, próprios de mensuração de energia livre de superfície, devido a limitação própria da metodologia.

A primeira pesquisa que relacionou a ELS com a adesão de microrganismos, demonstrando que superfícies que apresentarem uma ELS alta são mais susceptíveis a uma adesão maior de microrganismos, foi realizada por Glantz (GLANTZ, 1969), em que foi observada a formação da placa bacteriana sobre substratos com diferentes ELS montados sobre Próteses Parciais Fixas, no primeiro, terceiro e sétimo dia, concluindo que existe uma correlação positiva entre a ELS do substrato e a magnitude de acúmulo de placa bacteriana. Ellingensen et al (ELLINGSEN; ROLLA, 1994), demonstraram que a aplicação de óleo de silicone mais $0,3 \%$ de triclosan sobre as superfícies dentárias, diminui a ELS, tendo como resultado uma redução significativa na formação de placa bacteriana.

Yildirim et al (YILDIRIM et al., 2005) concluíram que após a modificação da superfície de resina acrílica, diminuindo a sua hidrofobicidade mediante a técnica de 
"Electric glow discharge", um aumento significativo na adesão da espécie C. albicans foi observado.

Na determinação da ELS de um sólido, quando o líquido utilizado na medição apresenta uma tensão superficial alta (fortes ligações moleculares internas), forma-se uma gota sobre a superfície do sólido onde foi colocado; entretanto, quando um líquido possui tensão superficial baixa, ele se espalha sobre uma área maior do sólido (ligação à superfície). Por outro lado, referindo-se a superfície do sólido, se esta apresenta uma ELS alta, o líquido se espalha ou molha a superfície; se a superfície apresenta uma ELS baixa, uma gota forma-se sobre o sólido. Este fenômeno é resultado da necessidade de um equilíbrio energético no sistema e da minimização da energia interfacial. A superfície sólida que apresenta uma ELS alta desejará ser coberta pelo líquido devido à interface formada (sólido - líquido) que baixaria sua energia. (DARVELL)

Um ângulo de contato de $90^{\circ}$ ou mais, normalmente caracteriza uma superfície não molhável, enquanto que ângulos menores que $90^{\circ}$, superfícies molháveis. No contexto da água, uma superfície molhável pode também ser denominada hidrofílica e, no caso das superfícies não molháveis, denominadas hidrofóbicas. As superfícies denominadas super-hidrofóbicas têm os ângulos de contato maiores de $150^{\circ}$, não mostrando quase nenhum contato entre a gota líquida e a superfície, enquanto que em superfícies extremamente hidrofílicas a gota se espalharia completamente formando um ângulo zero. Isso ocorre em superfícies com alta afinidade a água, incluindo materiais que absorvem água. Em muitas das superfícies hidrofílicas são encontrados ângulos de $10^{\circ}$ a $30^{\circ}$. Na maioria de superfícies hidrofóbicas que são incompatíveis com a água, se observam ângulos entre $70^{\circ}$ e $90^{\circ}$. Algumas superfícies, como as que contêm flúor (Teflon), a gota de água apenas toca a superfície e são formados ângulos entre $150^{\circ} \mathrm{e}$ $180^{\circ}$ (super-hidrofóbicas). Assim, o ângulo de contato provê informação da energia entre as superfícies interatuantes.(DARVELL)

\subsection{Película adquirida salivar : efeito na adesão da $C$. albicans}

A saliva é um fluido complexo. Diferentes glândulas na cavidade oral, respondendo a diversos estímulos, secretam saliva de composição diferente. As próteses 
totais, após colocadas na boca, em poucos minutos são cobertas por uma camada de proteínas salivares denominada película adquirida salivar, que serve como receptor para a adesão microbiana (RADFORD; CHALLACOMBE; WALTER, 1999). Após duas horas, podem ser encontradas nessa película: imunoglobulinas, mucinas, alfa-amilase, cistatinas, proteínas ricas em prolina, lizosima, glucosiltranferrase, albumina, fibrinogênio e componentes do soro (AL-HASHIMI; LEVINE, 1989; JENSEN; LAMKIN; OPPENHEIM, 1992; KRAUS et al., 1973; ROLLA; CIARDI; BOWEN, 1983). Estas substâncias encontradas podem sofrer variações a depender da superfície onde a película é formada (EDGERTON; LO; SCANNAPIECO, 1996) e também em função da composição da saliva.

Poucos trabalhos relatam o efeito da película adquirida salivar na adesão de $C$. albicans "in vivo". Alguns trabalhos "in vitro", como os de Nikawa e Edgerton (EDGERTON et al., 1993; NIKAWA et al., 1993; NIKAWA et al., 1992a), afirmaram que proteínas salivares podem servir de nutrientes para os microorganismos, cooperando com o seu crescimento, reprodução e o desenvolvimento da placa. (KOLENBRANDER; LONDON, 1993).

Os resultados reportados na literatura sobre o efeito da saliva na adesão da $C$. albicans a superfícies acrílicas é controversa, não existindo um consenso sobre o assunto. Enquanto alguns autores concluem que a saliva humana aumenta a adesão de $C$. albicans a superfícies acrílicas, (MILLSAP et al., 1999; SAMARANAYAKE, L.P.; NAIR, 1995; VASILAS et al., 1992) devido a componentes como a mucina, (DODDS; JOHNSON; YEH, 2005; EDGERTON et al., 1993; NIKAWA; HAMADA, 1990; NIKAWA et al., 1993 ) estaterina (JOHANSSON et al., 2000) (que facilitam a adesão da C. albicans a materiais resilientes embebidos em saliva) (NIKAWA et al., 2000) outros afirmam que a saliva diminui a adesão, (BOSCH et al., 2003; MAZA et al., 2002; MILLSAP et al., 1999; MOURA et al., 2006; NIKAWA et al., 1992b; PEREIRA-CENCI et al., 2007; SAMARANAYAKE, L.P.; MACFARLANE, 1980; WATERS et al., 1997) devido a componentes como lisozima, histanina, lactoferrina, calprotectina e S-IgA que interagem com as espécies de Candida diminuindo sua adesão. (CANNON; CHAFFIN, 2001; DODDS; JOHNSON; YEH, 2005; ELGUEZABAL; MAZA; PONTON, 2004; TANIDA et al., 2001) Ainda, alguns autores relataram que não há influência alguma da saliva na 
adesão da C. albicans aos materiais acrílicos (JIN et al., 2004; NIKAWA et al., 1992a; TARI et al., 2007).

As mais variadas teorias têm sido descritas para justificar esta falta de consenso na literatura, entre elas se destaca a falta de padronização na metodologia empregada para a realização dos testes, o que dificulta uma posterior comparação. A utilização de saliva estimulada ou não estimulada resulta numa diferença na composição protéica e viscosidade. (VEERMAN et al., 1996) Diferentes períodos de incubação, temperatura, purificação da saliva coletada e nutrientes que interferem com a viabilidade das células (DODDS; JOHNSON; YEH, 2005; JIN et al., 2004; RADFORD et al., 1998; SAMARANAYAKE, L.P.; MACFARLANE, 1980), além de variações entre os doadores, comprometem os resultados obtidos.

Com o intuito de determinar quais proteínas salivares servem de receptores para as células da $C$. albicans, vários pesquisadores como Newman (NEWMAN; BEELEY; MACFARLANE, 1996) e O' Sullivan (O'SULLIVAN et al., 1997) procuraram, aplicando diversas metodologias, revelar as proteínas básicas ricas em prolina, as quais estas células poderiam se unir. Desta forma, as proteínas IB-6 e Ps1 tem sido consideradas como receptores para a adesão da C. albicans. Estudos realizados em películas adquiridas sobre esmalte dentário confirmaram que após duas horas de formação, os aminoácidos encontrados diferem dos da saliva, indicando claramente que a película adquirida salivar é formada mediante uma absorção seletiva de macromoléculas. (TEUGHELS et al., 2006).

As características físico-químicas da superfície da película adquirida salivar, incluindo a composição, a densidade e a configuração, são altamente dependentes da natureza química e física da superfície onde esta foi formada; (BAIER; GLANTZ, 1978; DE JONG et al., 1984; FINE; WILTON; CARAVANA, 1984; LEE; ADAMSON; KIM, 1974; PRATT-TERPSTRA et al., 1991; PRATT-TERPSTRA; WEERKAMP; BUSSCHER, 1989; RUAN; DI PAOLA; MANDEL, 1986; SIPAHI; ANIL; BAYRAMLI, 2001) e isso é confirmado devido às características físico-químicas do substrato, que são transferidas através da película adquirida, e vão influenciar nas fases iniciais da adesão microbiana. (ABSOLOM; ZINGG; NEUMANN, 1987)

Além disso, é observado que a formação da película adquirida salivar modifica os 
substratos, fato fundamentado na relação que existe entre o tipo de proteína absorvida e a energia livre de superfície do substrato. Busscher (BUSSCHER, H.J.; BOS; VAN DER MEI, 1995) relataram o aumento da absorção de proteínas nos terminais hidrofílicos e a diminuição nos terminais hidrofóbicos, quando expôs polietileno à soro sanguíneo.

\subsection{Controle microbiano sobre as próteses totais}

O controle da adesão de microrganismos sobre as superfícies das próteses totais é considerado objetivo primordial de inúmeras pesquisas na literatura. A utilização de mecanismos com o intuito de provocar a morte, diminuição ou controle reprodutivo dos microorganismos, tem sido utilizados para o desenvolvimento de novas metodologias passíveis de serem incorporadas em protocolos de higiene de próteses totais

Aguirre et al (AGUIRRE et al., 1996), observaram que em pacientes que apresentam grandes depósitos de placa nas suas dentaduras, uma película adquirida salivar contínua em união direta com o acrílico, contendo células de C. albicans dispersas entre bactérias é observada, além de restos celulares epiteliais do estrato intermediário e parabasal e leucócitos polimorfonucleares. Nos pacientes sem depósitos macroscópicos de placa, existe uma película heterogênea e um grande número de blastoporos de Candida (FRANK; STEUER, 1985)

É relatado na literatura que os usuários de dentaduras geralmente apresentam uma higiene oral deficiente (BUDTZ-JORGENSEN et al., 2000; HOAD-REDDICK; GRANT; GRIFFITHS, 1990; KULAK-OZKAN; KAZAZOGLU; ARIKAN, 2002) e isso se deve, entre outros fatores, à falta de informação de parte dos profissionais de saúde, diminuição da destreza manual, retentividades na base da prótese e por existirem poucos produtos específicos para limpeza de dentaduras. (AMBJORNSEN; RISE, 1985; MURTOMAA; MEURMAN, 1992).

Os métodos de limpeza das próteses totais podem ser divididos em: mecânico, químico ou associação de métodos. Entre 60 a 90\% dos usuários de dentaduras utilizam exclusivamente o método mecânico, que preconiza a escovação com água e sabão ou dentifrício (ABELSON, 1985; JAGGER; HARRISON, 1995)

A maioria dos trabalhos científicos afirmam que, para uma alta eficácia na limpeza 
das dentaduras, uma associação de métodos deve ser implantada como a escovação da dentadura junto a imersão em soluções químicas,(ABELSON, 1985; BUDTZJORGENSEN, 1979; CHAN et al., 1991; DILLS et al., 1988; LOMBARDI; BUDTZJORGENSEN, 1993), procedimento capaz de diminuir os sinais clínicos da estomatite por prótese total (EP) (BARNABE et al., 2004; MAHONEN; VIRTANEN; LARMAS, 1998).

Uma grande variedade de produtos químicos utilizados para o controle da formação de biofilme microbiano sobre a base das próteses são reportados na literatura (LOMBARDI; BUDTZ-JORGENSEN, 1993; ODMAN, 1992). Enquanto alguns autores sugerem o uso de soluções higienizantes para auxiliar no controle de microorganismos (BASSON; QUICK; THOMAS, 1992; CHAN et al., 1991; GHALICHEBAF; GRASER; ZANDER, 1982; GLASS et al., 2004; GORNITSKY et al., 2002; MINAGI et al., 1987; MOORE; SMITH; KENNY, 1984), outros autores defendem a utilização de soluções químicas como as únicas capazes de eliminar os microorganismos que se aderem nas superfícies da prótese total ou que invadem o interior do acrílico. (CHAU et al., 1995; LIN et al., 1999)

Segundo Assad et al (ASAD; WATKINSON; HUGGETT, 1992), o objetivo da imersão das dentaduras em um agente desinfetante é a obtenção da limpeza, descontaminando as próteses e destruindo os microrganismos. Ela deve ser estabelecida com o intuito de remover e prevenir o acúmulo de placa microbiana, remover mucinas, restos alimentares, cálculos e pigmentação extrínseca. (BUDTZ-JORGENSEN, 1979)

A eleição de uma solução química para desinfecção de próteses totais deve ser baseada em diversos fatores, como a sua facilidade de uso e alta eficácia, capacidade de remoção de material orgânico, compatibilidade com os materiais de confecção de dentaduras, não ser tóxico para o usuário, deixar um mínimo sabor residual, apresentar ação bactericida e fungicida, além de um baixo custo que permita seu fácil acesso. (JAGGER; HARRISON, 1995).

Segundo Nakamoto et al (NAKAMOTO; TAMAMOTO; HAMADA, 1991) as soluções químicas utilizadas na manutenção da higiene oral de usuários de dentaduras podem ser divididas em 5 grupos: Peróxidos alcalinos, Hipocloritos alcalinos, ácidos, desinfetantes e enzimas. Neste estudo serão testados os desinfetantes, Hipoclorito de 
sódio $1 \%$ e o Gluconato de clorexidina $4 \%$, por pertencerem ao grupo de soluções químicas com mais estudos relatados na literatura que demonstraram eficácia na eliminação das espécies de Candida.

\subsubsection{Hipoclorito de sódio}

As soluções de hipoclorito foram inicialmente utilizadas como agentes branqueadores, sendo considerados os compostos de cloro mais antigos. Possuem alto poder germicida, amplo espectro antimicrobiano, de fácil manuseio e baixo custo (BLOCK, 1991). Entretanto é corrosivo a metais, sobretudo ao alumínio (FUKUZAKI, 2006).

O Hipoclorito de sódio foi recomendado por Labarraque para a prevenção da denominada "febre do verso" e outras doenças infecciosas.(ZEHNDER, 2006). Baseado nos trabalhos de laboratório de Koch e Pasteur, o hipoclorito ganhou uma ampla aceitação como agente desinfetante no final do século XIX. (ZEHNDER, 2006). Na primeira grande guerra, o químico Henry Drysdale Daking e o cirurgião Aléxis Carrel estenderam o uso do Hipoclorito de sódio tamponado a $0.5 \%$ como solução irrigadora de feridas com tecidos necróticos infectados. (MOHAMMADI, 2008)

Os compostos clorados existem em combinação com sódio, potássio, cálcio e magnésio. No corpo humano, formam parte do sistema imune não específico, gerado por reações dos neutrófilos. (TEST et al., 1984).

O Hipoclorito de sódio atua como solvente de tecidos orgânicos e gordura, incluindo ácidos graxos, transformando-os em sais de ácidos-graxos (Sabonete) e glicerol (Álcool), diminuindo a tensão superficial da solução restante (ESTRELA et al., 2002). Além disso, o Hipoclorito de sódio neutraliza os aminoácidos formando água e sal (reação de neutralização), com a saída de íons hidróxilas, ocasionando uma redução do PH. O ácido hipocloroso presente na solução Hipoclorito de sódio, quando em contato com o tecido orgânico atua como solvente, liberando cloro que se combina com o grupo de aminoácido formando cloraminas (reação de cloraminação) que interfere com o metabolismo celular. O ácido hipocloroso (HOCL) e íons de hipoclorito (OCL) leva a degradação dos aminoácidos e a hidrólise. (ESTRELA et al., 2002) 
Considerando as propriedades físico-químicas do Hipoclorito de sódio, podese considerar como um forte agente básico $(\mathrm{pH}>11)$, que quando em contato com proteínas de tecido orgânico, libera nitrogênio, formaldeído e acetaldeído; além disso, ocorrem as dissociações de uniões peptídicas, resultando na dissolução de proteínas (HAUMAN; LOVE, 2003). O alto $\mathrm{pH}$ do hipoclorito interfere na integridade da membrana citoplasmática provocando uma irreversível inibição enzimática.(ESTRELA et al., 2002)

Contrário a Clorexidina, o Hipoclorito de sódio parece não apresentar efeito de substantividade. Gomes et al (GOMES et al., 2007) testaram o efeito do Gel de Clorexidina 2\% e Hipoclorito de sódio 5.25\% sobre a superfície de cones de Resilon e gutapercha endodôntica, procurando um possível efeito antibacteriano residual. Os autores concluíram que a exposição de cones de Resilon a o Gel de Clorexidina 2\% por 10, 20 e 30 minutos apresentou efeito antibacteriano residual frente a E. Faecalis, enquanto que nenhuma inibição foi observada após a imersão em Hipoclorito de sódio a $5.25 \%$.

Mas alguns trabalhos afirmam que concentrações sub-inibitórias (1/50) do desinfetante são capazes de inibir a adesão a superfícies acrílicas. De acordo com o trabalho do Webb et al (WEBB et al., 1995), quando a espécie C. albicans é colocada em contato com concentrações sub-inibitórias de Hipoclorito de sódio (1/50) uma diminuição na adesão a superfícies acrílicas é observada, enquanto que em outras espécies de Candida sp. um aumento ou nenhum efeito na adesão é observada, associando este efeito ao fato de que o mecanismo de adesão microbiana a superfícies inertes está associado a forças não especificas como a hidrofobicidade

\subsubsection{Clorexidina}

A Clorexidina é um composto alcalino, estável, em forma de sal. A forma mais comum de preparação para uso oral é o Gluconato de clorexidina, composto capaz de ser solúvel em água. Possui pH fisiológico, sendo dissociável, o que permite a liberação da Clorexidina carregada positivamente (GREENSTEIN; BERMAN; JAFFIN, 1986; 
MOHAMMADI; ABBOTT, 2009). Apresenta como vantagem, frente ao Hipoclorito de sódio, a sua biocompatibilidade.

Em baixas concentrações $(0.2 \%)$, atua em substâncias de baixo peso molecular, especificamente potássio e fósforo. Enquanto que em altas concentrações (2\%) a clorexidina é bactericida, precipitando o conteúdo citoplasmático resultando na morte celular (GOMES et al., 2003)

A Clorexidina é disponibilizada como acetato, gluconato e sais hidroclorados. É considerada uma bisguanina catiônica sintética que consiste em dois anéis simétricos de 4-clorofenil e dois grupos biguanida conectados por uma cadeia central de hexametileno (GREENSTEIN; BERMAN; JAFFIN, 1986). É uma molécula carregada positivamente, hidrofóbica e lipofílica, que interage com os fosfolípideos, lipopolisacarídeos da membrana celular do microorganismo, entrando na célula por mecanismos de transporte passivo ou ativo. (ATHANASSIADIS; ABBOTT; WALSH, 2007). Sua eficácia está baseada na interação que resulta da sua carga positiva com a carga negativa dos grupos fosfatos, atuando na membrana celular do microorganismo, alterando o equilíbrio osmótico (GOMES et al., 2003), incrementando a permeabilidade da membrana celular, permitindo a entrada de moléculas de Clorexidina no interior da célula.(MOHAMMADI; ABBOTT, 2009).

Soluções aquosas de Clorexidina apresentam um alto espectro antimicrobiano em baixas concentrações e é especialmente efetiva frente a $C$. albicans. A Clorexidina une-se a tecidos orais, sendo liberada lentamente durante extensos períodos, fenômeno denominado substantividade, podendo eficientemente inibir a adesão inicial de fungos e outros microorganismos, e conseqüentemente diminuir a formação de biofilme. (MOHAMMADI; ABBOTT, 2009),

Lamb DJ e Martin MV (LAMB; MARTIN, 1983), induziram candidose oral em ratos e testaram o efeito da incorporação de Clorexidina em varias proporções $(2.5 \%, 5 \%$, $7.5 \%$ e $10 \% \mathrm{w} / \mathrm{w}$ ) a uma resina autopolimerizável no crescimento de C. albicans. Os autores concluíram que a difusão de Clorexidina a partir do acrílico teve efeito antifúngico quando misturado numa proporção de $7.5 \%(\mathrm{w} / \mathrm{w})$. Nessa concentração a candidose oral foi curada ou prevenida. 
McCourtie et al, (MCCOURTIE; MACFARLANE; SAMARANAYAKE, 1985) testaram "in vitro", o efeito do pré tratamento de acrílico para dentadura com Gluconato de clorexidina na adesão de C. albicans (GDH2346). Concluindo, observaram que houve uma diminuição na adesão de $C$. albicans e esta foi significante após a imersão do acrílico por 30 minutos em Gluconato de clorexidina a $2 \%$.

Spiechowicz et al,(SPIECHOWICZ et al., 1990) testaram o efeito inibitório de diferentes agentes antifúngicos no crescimento da C. albicans. Foi avaliada a Nistatina, Gluconato de clorexidina 0,12\% e Histidina. Os autores concluíram que o pré-tratamento da resina acrílica com Nistatina, seguido de secagem do espécime, e do Gluconato de clorexidina foi totalmente efetivo. No caso da Clorexidina foi observada a prevenção na adesão e o crescimento de C. albicans até um período de 8 dias mediante análise de turvação do meio de cultura. Não foram observados efeitos inibitórios quando os espécimes foram pré-tratados com Nistatina ou Histidina, seguido por imersão em PBS.

\subsubsection{Efetividade do Hipoclorito de sódio e Gluconato de clorexidina na desinfecção de Próteses Totais.}

Soluções químicas têm sido empregadas com sucesso para a desinfecção de próteses totais. Na literatura existe muita controvérsia sobre o tema, em virtude da efetividade da desinfecção estar diretamente relacionada a diversas variáveis como a concentração e tipo do microrganismo, tipo e concentração da sustância química, tempo de exposição, (ÁBALOS, 2005; LIN et al., 1999; MA; JOHNSON; GORDON, 1997; PAVARINA et al., 2003; SAUNDERS et al., 1998) quantidade de resíduos orgânicos acumulados (MOLINARI; RUNNELLS, 1991; RUTALA; WEBER, 1997), natureza do substrato (se possui poros) e o pH da solução (RUTALA; WEBER, 1997).

No que tange ao Hipoclorito de sódio, a literatura é vasta em comprovar sua eficácia. A maioria dos trabalhos apresenta resultados relacionados ao Hipoclorito de sódio 5.25\%. Saunders (SAUNDERS et al., 1998) aconselha a imersão da prótese total em Hipoclorito de sódio $5.25 \%$ diluído a $1: 10$ por 10 minutos; enquanto que outros aconselham a mesma concentração diluída 1:5 a 1:100 em intervalos de 10 a $30 \mathrm{~min}$ (COTTONE; MOLINARI, 1987) 
Ghalichebaf, et al (GHALICHEBAF; GRASER; ZANDER, 1982), testaram 4 soluções desinfetantes para próteses totais, concluindo que os agentes mais efetivos foram os que apresentavam uma alta proporção de Hipoclorito de sódio. Observações similares foram feitas por Basson (BASSON; QUICK; THOMAS, 1992) com a utilização da solução Milton ${ }^{\circledR}$ 4\% (Hipoclorito de sódio $0.04 \%$ e cloreto de sódio $0.66 \% \mathrm{v} / \mathrm{v}$ ). Moore, et al (MOORE; SMITH; KENNY, 1984), concluíram que as soluções de Hipoclorito de sódio eliminaram a placa na dentadura em curtos tempos de imersão.

Enquanto que (RUDD et al., 1984) descreve a utilização do Hipoclorito de sódio $5.25 \%$ não diluído em um tempo de imersão de 5 minutos, outros trabalhos preconizam a imersão em tempos diferentes (BELL et al., 1989; CHAU et al., 1995; SAUNDERS et al., 1998).

McGowan et al (MCGOWAN; SHIMODA; WOOLSEY, 1988), relataram a utilização do Hipoclorito de sódio não produz dano nas estruturas metálicas, testando o Hipoclorito de sódio nas concentrações de $2 \%, 3 \%, 4 \%$ e 5,25\% em imersões de 3,5 e 30 minutos em próteses parciais removíveis. As imersões em Hipoclorito de sódio 2\% por 5 minutos e $5.25 \%$ por 3 minutos também foram efetivas na desinfecção da resina acrílica sem dano à estrutura metálica.

Yilmaz et al (YILMAZ et al., 2005), concluíram que a imersão por 5 minutos em solução de Hipoclorito de sódio a $5.25 \%$ é mais efetiva que a solução a $2 \%$, embora ambas tenham reduzido o número de microorganismos testados.

Buergers et al (BUERGERS et al., 2008), avaliaram o efeito de 10 métodos de desinfecção com o intuito de organizar em ordem decrescente, de acordo com a colonização de C. albicans em um material resiliente de reembasamento. Neste estudo, concluiu-se que a imersão em Hipoclorito de sódio 1\%, pastilhas efervescentes (perborato de sódio) por 10 minutos e uso do micro-ondas (prótese imersa em água) a $800 \mathrm{~W}$ por 6 minutos foram os métodos mais efetivos em comparação com a imersão em glutaraldeído $2 \%$, peróxido de hidrogênio 3\%, vinagre, Listerine (Álcool) e Triclosan 0,3\% que não apresentaram diferença estatística com o grupo controle (imersão em PBS por 10 minutos). 
Comparando a eficácia da imersão em Hipoclorito de sódio a 2\% por 5 horas frente ao uso de micro-ondas por 5 minutos a $650 \mathrm{~W}$, Baysan, Whiley e Wright (BAYSAN; WHILEY; WRIGHT, 1998), relataram que a imersão em Hipoclorito de sódio foi mais eficiente na eliminação de microorganismos.

No que tange a Clorexidina, a solução é comercializada para uso anti-séptico na cavidade oral em baixas concentrações, enquanto que em altas concentrações é utilizada como solução desinfetante para imersão.

De Paola et al (DEPAOLA; MINAH; ELIAS, 1984) testaram o efeito desinfetante de 14 produtos disponíveis no mercado (Kleenite, Effervedent, polident, Mersene, Gluconato de clorexidina 1\%, clorasseptico, listerine, greene mint, signal, scope, lavoris, cepacol, betadine) contra vários microorganismos patogênicos (P. Aeruginosa, Kleibiela Pneumoneae, Enterobacter cloacae, E. Coli, E. Auerus, C. Albicans e C. Glabrata). Os melhores agentes com atividade inibitória e bactericida foram o Kleenite, Effervedent, Polident, Listerine, Clorasséptico e Gluconato de clorexidina 1\%.

MacNeill et al (MACNEILL et al., 1997), testaram o efeito da clorexidina a $0.12 \%$ e a tetraciclina tetraclorada frente a Candida albicans, concluindo que o diGluconato de clorexidina a $0.12 \%$ inibiu o crescimento da $C$. albicans além de promover profundas mudanças na morfologia celular; enquanto que a tetraciclina tetra clorada, mesmo em altas concentrações, não conteve o seu crescimento.

Lamfon et al (LAMFON et al., 2005), avaliaram a susceptibilidade de biofilme de C. albicans a agentes antifúngicos. O Gluconato de clorexidina $0.3 \%$ não se mostrou eficaz e, na concentração de $1.25 \%$, reduziu o crescimento de Candida sp. Entretanto na concentração de $2.5 \%$ não foi encontrado crescimento fúngico.

Sesma et al (SESMA et al., 1999), avaliaram o efeito de 3 métodos caseiros de higienização de próteses totais, constatando que o uso exclusivo de escova e dentifrício não são suficientes para a eliminação da placa bacteriana e que a combinação do método mecânico com imersão em Gluconato de clorexidina a $2 \%$ foi o método mais eficaz. Ainda nesta concentração, a clorexidina junto ao fluconazol, no tratamento da estomatite por prótese total, reportou uma melhora significativa da inflamação do palato e diminuição na colonização da C. albicans, quando comparados ao tratamento isolado do fluconazol ou somente a troca das próteses (KULAK; ARIKAN; DELIBALTA, 1994). 
Ucar Barroeta et al (BARROETA; MÉNDEZ; LELIS, 2007), avaliaram a eficácia de 4 agentes químicos (Hipoclorito de sódio 2\%, acido acético 5\%, Peróxidos alcalinos e Gluconato de clorexidina $0.12 \%)$ em diferentes tempos de imersão $(5,10,15,20$ minutos e 8 horas). Os autores concluíram que todos os desinfetantes foram eficazes a partir de 20 minutos de imersão na eliminação de $C$. albicans.

Kulak et al (KULAK; ARIKAN; DELIBALTA, 1994), compararam a efetividade da escovação com imersão em soluções efervescentes (corega, dentpur e Fittydent), soluções desinfetantes (Hipoclorito de sódio 5\% e Gluconato de clorexidina a 1\%) e um enxuagatório bucal (Ipanol). Imagens microscópicas demonstraram que todos os métodos de limpeza foram efetivos, mas a imersão em soluções desinfetantes apresentou resultados mais expressivos. As soluções efervescentes e a escovação foram similares entre si e apresentaram uma efetividade superior comparada a imersão em Ipanol.

Pavarina et al (PAVARINA et al., 2003), analisaram a eficácia de protocolos de limpeza de próteses totais através da imersão por 10 minutos em cada uma das seguintes soluções desinfetantes: Gluconato de clorexidina 4\%, Hipoclorito de sódio 1\%, Biocide (Iodoforo) e Amosan (peróxido alcalino). Todas as soluções desinfetantes foram capazes de evitar o crescimento microbiano, exceto o Biocide (iodoforo) que não mostrou a mesma eficácia das demais soluções na eliminação de microorganismos.

Da Silva et al (DA SILVA et al., 2008), avaliaram a eficácia antimicrobiana e os efeitos sobre a rugosidade superficial de uma resina acrílica quimicamente polimerizada, reportando que as soluções de maior eficácia foram Hipoclorito de sódio 1\%, Glutaraldeído 2\%, Gluconato de clorexidina 2\% e o vinagre $100 \%$ respectivamente, enquanto que o perborato de sódio $3.8 \%$ apresentou eficácia intermediária. O perborato de sódio não foi considerado uma alternativa eficiente para desinfecção de próteses totais. Com referência a rugosidade, houve uma diminuição com o uso do Gluconato de clorexidina $2 \%$ e aumento significativo com o uso do perborato de sódio $3.8 \%$.

Devido a alta variação dos resultados reportados na revisão de literatura realizada por Nikawa (NIKAWA et al., 1999), pode-se concluir que este fato se deve a falta de padronização nas metodologias utilizadas para todos os trabalhos e da dependência da metodologia utilizada na avaliação da eficácia das substâncias desinfetantes. Assim, os resultados obtidos "in vivo" não se apresentaram tão eficazes como os resultados "in 
vitro". Sugerem que para a avaliação da eficácia dos desinfetantes, deve ser tomado em conta não somente a placa residual (microorganismos viáveis), e sim observar a capacidade de inibir o subseqüente crescimento de placa microbiana. Finalmente, os autores consideraram que para uma solução desinfetante ser considerada efetiva, ela deve ter uma taxa de remoção do biofilme maior que $90 \%$ ou a permanência de uma quantidade menor a 500 células viáveis no espécime, devido a redução no $\mathrm{pH}$ em função da produção ácida dos microrganismos restantes não ser significante dentro de 24 horas. 


\section{PROPOSIÇÃO}

Devido a existência de poucos trabalhos na literatura analisando o efeito das soluções desinfetantes Hipoclorito de sódio 1\% e Gluconato de clorexidina 4\%, sobre as características físico-químicas das resinas acrílicas termopolimerizáveis, e também do efeito da formação da película adquirida salivar e sua possível associação a adesão de $C$. albicans, este trabalho teve os seguintes objetivos:

- Analisar o efeito das soluções desinfetantes Hipoclorito de sódio $1 \%$ e Gluconato de clorexidina 4\% na hidrofobicidade superficial da resina acrílica termopolimerizável inicialmente e após 1, 7, 15 e 30 ciclos de desinfecção química.

- Analisar o efeito da formação da película adquirida salivar sobre a hidrofobicidade superficial da resina acrílica termopolimerizável inicialmente e após 1, 7, 15 e 30 ciclos de desinfecção química.

- Analisar o efeito das soluções desinfetantes Hipoclorito de sódio $1 \%$ e Gluconato de clorexidina 4\% na adesão da C. albicans sobre resina acrílica termopolimerizável inicialmente e após $1,7,15$ e 30 ciclos de desinfecção química.

- Analisar o efeito da formação da película adquirida salivar na adesão da $C$. albicans sobre resina acrílica termopolimerizável inicialmente e após 1, 7, 15 e 30 ciclos de desinfecção química.

- Verificar a existência de correlação entre a hidrofobicidade superficial e adesão de C. albicans à resina acrílica termopolimerizável após 30 ciclos de desinfecção. 


\section{MATERIAIS E MÉTODO}

Os métodos foram divididos em: experimentos I e II e realizados na seguinte ordem cronológica:

Experimento I: Hidrofobicidade superficial de Resina acrílica termopolimerizável após desinfecção em soluções químicas.

1. Confecção e inclusão dos padrões de silicona

2. Manipulação, inserção e termopolimerização da resina acrílica

3. Tratamento dos espécimes

4. Desinfeç̧ão em soluções químicas

5. Formação de película adquirida salivar

6. Medição do ângulo de contato

Experimento II: Colonização de $C$. albicans sobre resina acrílica termopolimerizável após desinfecção em soluções químicas.

1. Confecção e inclusão dos padrões de silicona

2. Manipulação, inserção e termopolimerização da resina acrílica

3. Tratamento dos espécimes

4. Desinfecção em soluções químicas

5. Formação de película adquirida salivar

6. Fase de adesão de $C$. albicans

7. Processamento dos espécimes para microscopia fluorescente

8. Análise dos corpos de prova no microscópio fluorescente 


\subsection{Experimento I: Hidrofobicidade superficial de Resina acrílica} termopolimerizável após desinfecção em soluções químicas.

\subsubsection{Confecção e inclusão dos padrões de silicona}

Para a confecção dos corpos de prova utilizados neste experimento, inicialmente foram obtidos padrões de silicona de condensação de uso laboratorial Zetalabor (Hard 85 shore-A, Zhermack, Badia Polesine/RO, Italy). Esses padrões foram confeccionados a partir de uma matriz metálica de forma retangular, medindo $10 \times 25 \times 2 \mathrm{~mm}$. (FIGURA 1)

A matriz metálica foi preenchida pela silicona de condensação e prensada entre duas placas de vidro (JON Com de produtos odontolaunógicos LTDA, São Paulo/SP, Brasil) previamente isoladas com vaselina sólida (Hemafarma Com. E Ind farmacêutica LTDA, São Gonçalo/RJ, Brasil), sob peso de 5kg, por aproximadamente 10 minutos. Em seguida, o padrão de silicona foi removido da matriz e os excessos cortados com auxílio de uma lâmina de estilete. Após a polimerização da silicona, os padrões foram incluídos na mufla metálica da marca DCL de número 6. (DE REZENDE PINTO et al., 2009) (FIGURA 1).

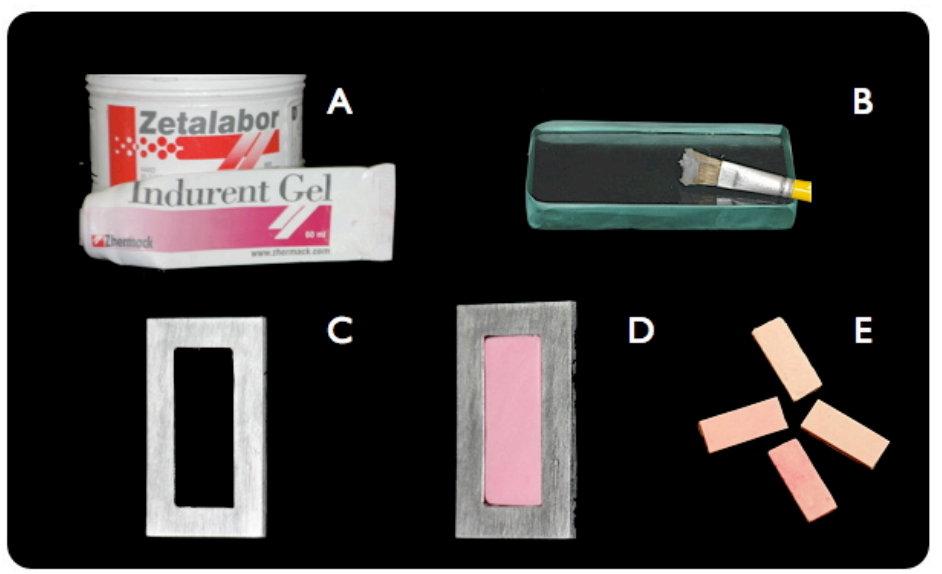

Figura 1: A: Silicona de condensação de uso laboratorial Zetalabor. B: Isolamento com Vaselina sólida das placas de vidro. C: Matriz metálica. D: Padrão de silicona após polimerização. E: Padrão de silicona finalizado. 


\section{- Inclusão dos padrões de silicona:}

Os padrões de silicona foram retirados da matriz e incluídos em muflas de latão polido com pino $\mathrm{n}^{\circ} 6$ (Mac Artigos odontológicos e prótese Ind. e Com. LTDA, São Paulo/SP, Brasil), inicialmente isoladas com vaselina sólida. Posteriormente, as muflas metálicas foram preenchidas com gesso pedra tipo III (Gesso Pedra Herodent - Vigodent S/A Ind. e Com., Rio de Janeiro/RJ, Brasil), manipulado e espatulado, conforme orientações do fabricante, em cuba de borracha (Dentalbrand Comercial, São Paulo/SP, Brasil) com espátula para gesso (Indusbello Ind. de Instr. Odontológicos, Londrina/PR, Brasil), sob vibração.

Após a presa do gesso, os padrões de silicona foram fixados uma nova camada de gesso à mufla. Esperou-se o tempo de presa da segunda camada e em seguida, aplicou-se vaselina sólida em toda superfície. A contra mufla também recebeu uma camada de vaselina sólida nas suas superfícies internas e posteriormente, posicionada e devidamente preenchida com gesso pedra tipo III, conforme condições técnicas descritas anteriormente.

As muflas permaneceram na prensa hidráulica (VH Equipamentos médicos Odont. Acess. LTDA., Araraquara/SP, Brasil) com 0,5 Kgf de pressão, por uma hora, e em seguida, abertas para a remoção das matrizes de silicone e realização do exame do molde no gesso. (DE REZENDE PINTO et al., 2009)

(FIGURA 2). 


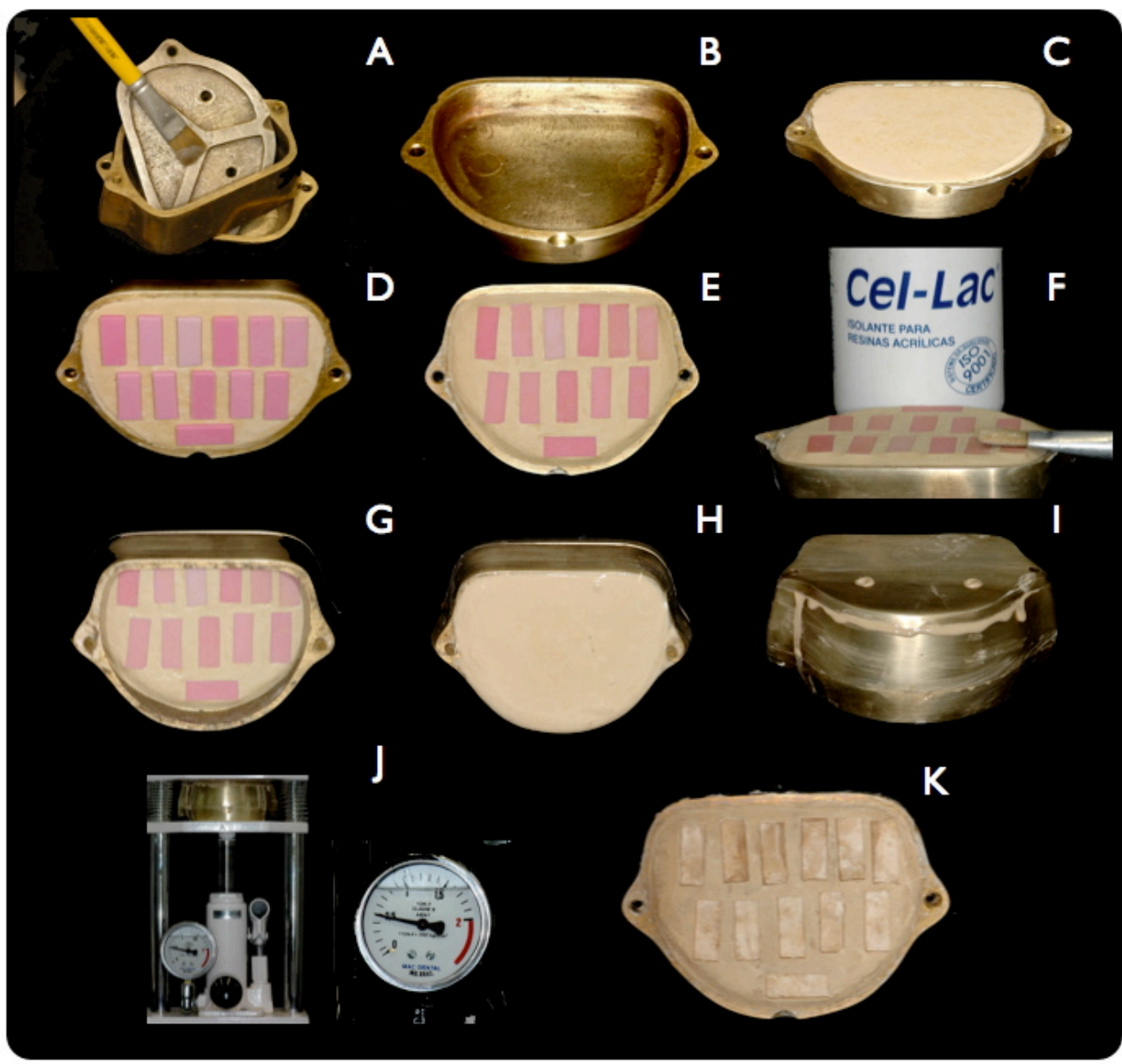

Figura 2: A: Isolamento da mufla, contra mufla e tampa com vaselina solida. B: Mufla. C: Prenchimento da mufla com gesso tipo III D: Colocação dos padrões de silicona. E: Padrões de silicona fixados na mufla. F: Isolamento dos padrões de silicona com Cel-lac ${ }^{\circledR}$. G: Assentamento da contramufla. H: Prenchimento da contramufla com gesso tipo III. I: Colocação da tampa. J: Mufla na prensa hidráulica por 30 minutos. K: Remoção das matrizes de silicona e exame do molde de gesso.

\subsubsection{Manipulação, inserção e termopolimerização da resina acrílica.}

Para prensagem, foi utilizada a resina acrílica termopolimerizável Lucitone 550 cor rosa médio (Dentsply International INC., Chicago/IL, USA), homogeneizada com auxílio de uma espátula n 31 (SS White Art. Dentários LTDA, Rio de Janeiro/RJ, Brasil) em recipiente de vidro (Paladon, Pr. Ind. e Comércio de produtos odontológicos, Florianópolis/SC, Brasil), utilizando-se a proporção de $21 \mathrm{~g}$ de pó para $10 \mathrm{ml}$ de líquido, conforme orientações do fabricante. $\mathrm{O}$ interior dos moldes de gesso foi isolado com isolante para resina acrílica (Cel-Lac, S.S. White Artigos Dentários, Rio de Janeiro, RJ. 
Brasil), com auxílio de um pincel de pêlo de marta (Condor, ${ }^{\circ} 456$, Condor S.A., São Bento do Sul/SC, Brasil) e preenchido com a resina acrílica na fase plástica. A base da mufla foi coberta com uma folha de papel celofane e fechada com a sua respectiva porção superior para ser prensada em prensa hidráulica sob pressão inicial de $0,5 \mathrm{kgf}$. No momento em que o ponteiro da prensa hidráulica se apresentou estável, a pressão foi aumentada para $1 \mathrm{kgf}$ e por fim, até atingir 1,5 kgf. Após a estabilização do ponteiro em 1,5 kgf e escoamento completo do excesso da resina acrílica, a mufla foi novamente aberta, o papel celofane removido, a película de resina acrílica excedente eliminada com o auxílio de uma espátula Lecron (S.S. White Art. Dentários LTDA, Rio de Janeiro/RJ, Brasil). A mufla foi novamente fechada e levada para prensa hidráulica sob pressão de $1,5 \mathrm{kgf}$ durante 30 minutos.

Decorrido esse período, a mufla foi colocada em uma prensa de aço inoxidável (Metal Vander Aparelhos para Ortodontia, Piracicaba/SP, Brasil), à polimerizadora microprocessada digital, modelo Banho Maria (Solab, Piracicaba/SP, Brasil) (Figura 3), para que se procedesse a termopolimerização com a seguinte programação: a temperatura da água elevada até $73^{\circ} \mathrm{C}$ e estabilizada durante 90 minutos, em seguida, atingiu $100^{\circ} \mathrm{C}$, que foram mantidos por mais 30 minutos (FIGURA 3). 


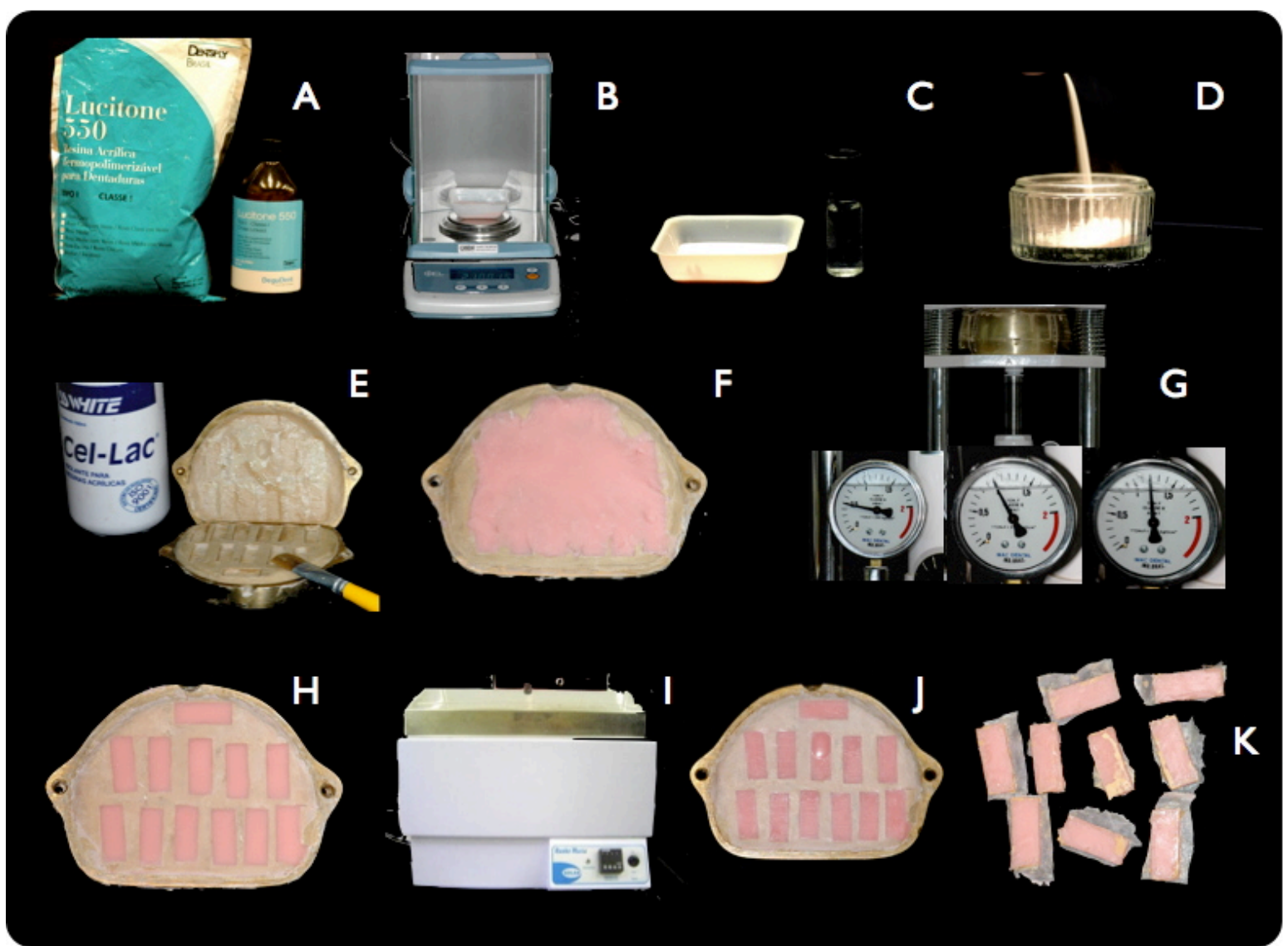

Figura 3: A: Lucitone 550 ®, cor rosa médio. B: Pesagem do pó do acrílico (21 g) em balança digital. C: Pó e liquido do acrílico D: Colocação do apo ao acrílico para mistura. E: Isolamento do molde de gesso com Cel-lac ${ }^{\circledR}$. F: Colocação da resina acrílica no molde de gesso na fase plástica. G: Colocação da mufla em prensa hidráulica com pressão de 0,5 1.0 e $1.5 \mathrm{Kg}$. H: Mufla aberta após 30 minutos na prensa hidráulica. I: Termopolimerizadora digital. J: Espécimes após concluído o ciclo de polimerização. K: Espécimes pré-tratados. 


\subsubsection{Tratamento dos espécimes}

Posteriormente à demuflagem, os excessos (rebarbas) dos espécimes de resina acrílica foram desgastados com o auxílio de uma fresa de tungstênio e em seguida os espécimes foram fixados em dispositivos de resina acrílica em forma de disco, para permitir o polimento em uma politriz metalográfica (marca Arotec, modelo APL 4 Cotia/SP, Brasil), com dispositivo para polimentos múltiplos, utilizando lixa de silicone (3M, Sumaré/SP, Brasil) na granulação 600, aplicada sob refrigeração durante 4 minutos com carga de 107 gramas. As amostras foram limpas mediante imersão em água deionizada em ultra-som (Ultrasonic Cleaner- Arotec, Cotia/SP, Brasil) por 20 minutos. Posteriormente foi conferida a rugosidade superficial ( $\mathrm{Ra}$ ) inicial nos padrões de resina acrílica, utilizando o aparelho rugosímetro Hommel Tester T 1000 basic (Hommelwerke $\mathrm{GmbH}$, ref. \# 240851, Schwenningen, Germany) onde se padronizou uma rugosidade superficial próxima a $2 \mu \mathrm{m}$.

Todos os espécimes foram acondicionados individualmente em poços de placas de cultura de células de 24 poços (TPP, Trasadingen, Switzerland), contendo $2 \mathrm{~mL}$ de água destilada, por 12 horas a uma temperatura de $37^{\circ} \mathrm{C}$ procurando a eliminação de monômero residual (MOURA et al., 2006), em estufa (FANEM- controlador microprocessado modelo 502 C Orion- estufa de cultura- Guarulhos/SP- Brasil). Em seguida, os espécimes foram deixados em ar livre para secagem e embalados individualmente para esterilização por meio de óxido de etileno (Acecil - Central de esterilização comércio e indústria, Campinas/SP, Brasil) (MIMA et al., 2008; SILVA et al., 2006). (FIGURA 4) 


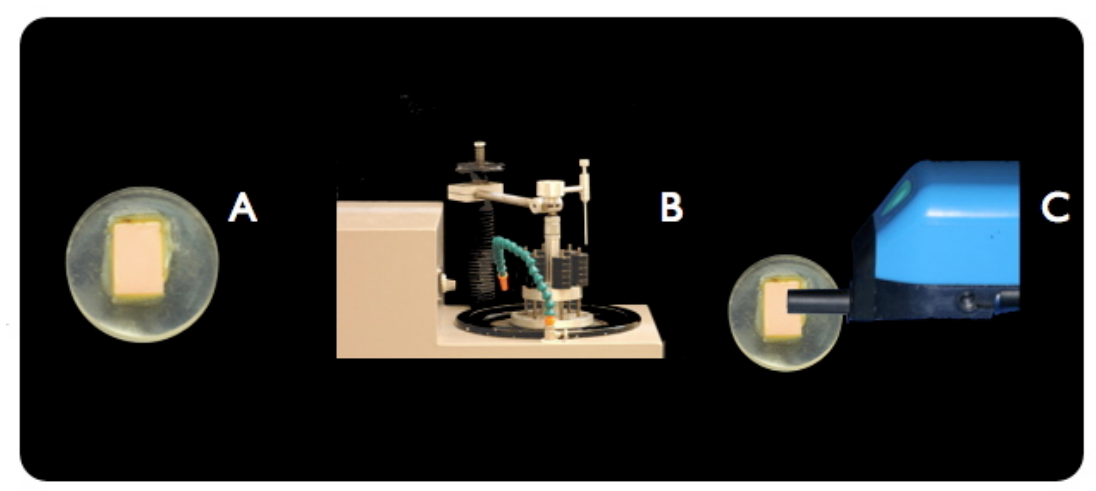

Figura 4: A: Espécime fixado em dispositivo circular. B:Politriz Metalográfica. C: Aferimento de Rugosidade superficial.

\subsubsection{Desinfecção em soluções químicas.}

18 corpos de prova foram divididos aleatoriamente em um grupo controle e 2 grupos experimentais (soluções químicas), (TABELA 1), que comprovadamente evidenciaram a desinfecção de resinas acrílicas para bases de dentaduras, a partir de trabalhos da literatura:

Cada grupo foi conformado por 6 espécimes que foram submetidos a ensaios de desinfecção. Desinfecção de 10 minutos em cada grupo era equivalente a 1 ciclo, objetivando simular "in vitro" a implementação de um protocolo de desinfecção de dentadura até 30 ciclos. O período total de avaliação (30 ciclos) foi dividido em vários sub-períodos (Inicial, 1, 7, 15 e 30 ciclos), onde em cada sub-período eram realizas mensurações de hidrofobicidade superficial antes e depois da formação da película adquirida salivar.

Grupo 1 (Controle): Os corpos de prova $(\mathrm{n}=6)$ foram imersos em $2 \mathrm{~mL}$ de água destilada por 10 minutos, simulando uma desinfecção. Os ensaios no grupo controle foram realizados sem interrupção de desinfecção. Nos grupos experimentais os ciclos foram interrompidos para a realização de lavagens em água destilada. Devido ao grupo controle estar imerso em água destilada, foi desconsiderada a necessidade de interromper os ciclos de desinfecção, deixando os espécimes completar o tempo total equivalente a cada sub-período avaliado. 
Grupo 2: imersão em Hipoclorito de sódio a 1\% por 10 minutos. (PAVARINA et al., 2003). Os corpos de prova ( $\mathrm{n}=6$ ) foram imersos em $2 \mathrm{ml}$ de uma solução de Hipoclorito de sódio a 1\% por 10 minutos. (Calendula Farmácia de Manipulação, Bauru/SP, Brasil). Em seguida, os espécimes foram lavados em $2 \mathrm{ml}$ de agua destilada por 1 minuto por 3 vezes consecutivas, seguido de secagem em papel absorvente estéril para a posterior realização de um novo ciclo de desinfecção, até completar cada sub-período de avaliação.

Grupo 3: imersão em Gluconato de clorexidina 4\% por 10 minutos. (PAVARINA et al., 2003) Os corpos de prova $(n=6)$ foram imersos em Gluconato de clorexidina 4\% por 10 minutos (Calendula Farmácia de Manipulação, Bauru/SP, Brasil). Após foram repetidos os procedimentos de lavagem e secagem dos espécimes realizados no grupo 2 . (FIGURA 5)

Tabela 1: Divisão dos grupos avaliados no experimento I

\begin{tabular}{lccc}
\hline Grupos & N & $\begin{array}{c}\text { Tempo de } \\
\text { Desinfecção }\end{array}$ & Intervalos Avallados \\
\hline Grupo Controle & 6 & 10 minutos & Inicial, 1, 7, 15, 30 \\
\hline Hipoclorito de Sódio 1\% & 6 & 10 minutos & Inicial, 1, 7, 15, 30 \\
\hline & 6 & 10 minutos & Inicial, 1, 7, 15, 30 \\
\hline
\end{tabular}




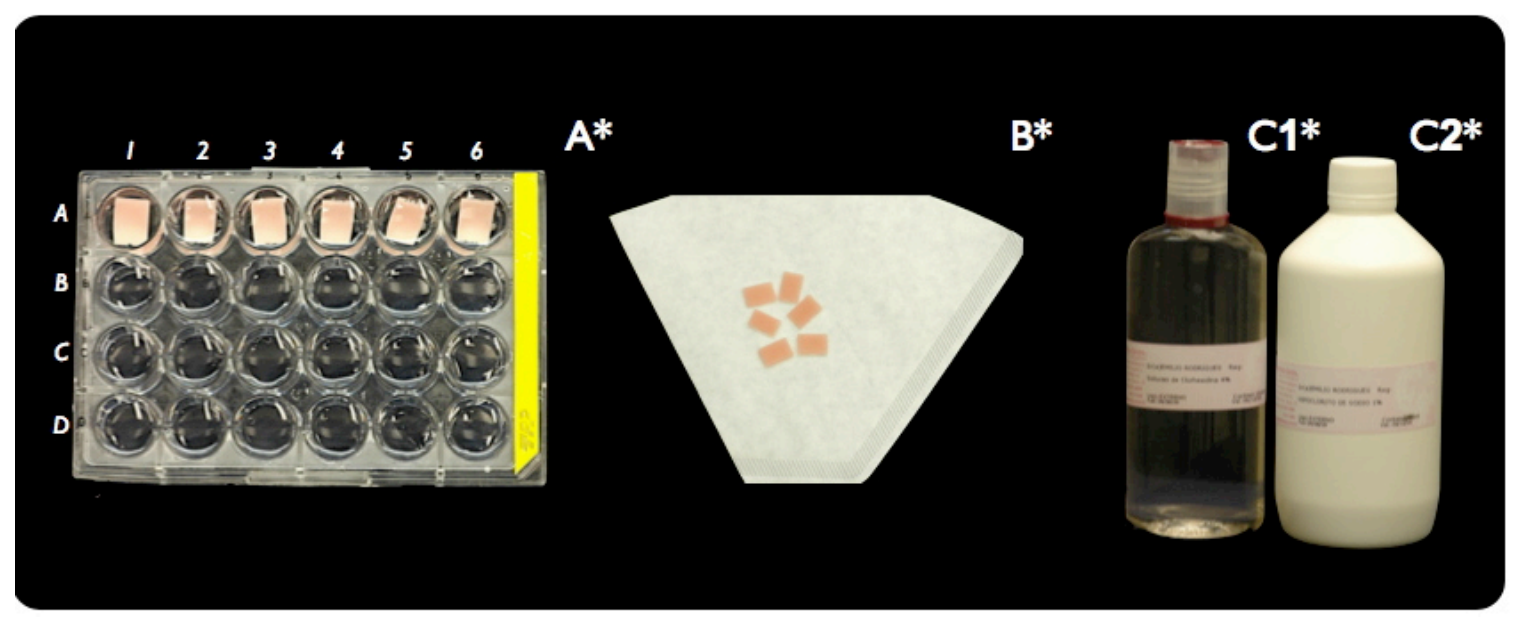

Figura 5: A*: Placa de cultura de células de 24 poços. Fila A (1-6): Espécimes em solução desinfetante. Filas BCD (1-6): Poços destinados a lavagem dos espécimes com água destilada . B*: Secagem dos espécimes com papel absorvente estéril após cada ciclo de desinfecção. C1*: Gluconato de clorexidina 4\% (Calendula Farma). C2*:Hipoclorito de sódio 1\% (Calendula Farma)

\subsubsection{Formação de película adquirida salivar}

Para a formação de película adquirida salivar os espécimes de cada grupo foram pré-tratados com saliva humana clarificada por meio de centrifugação, simulando a influência da formação de película adquirida salivarna hidrofobicidade superficial da resina acrílica termopolimerizável Lucitone (Lucitone 550- Dentsply International INC, Chicago, IL, USA). Para a realização deste método, foi coletada saliva humana de 1 voluntário, sem doença periodontal ativa ou presença de cáries; que não utilizou antibióticos, bochechos orais ou outra medicação nos 3 últimos meses que pudessem intervir com a composição ou fluidez salivar.(MOURA et al., 2006; SARDIN et al., 2004)' O doador assinou um termo de consentimento informando sobre sua participação na pesquisa e o projeto foi encaminhado para aprovação pelo comitê de ética em pesquisa da Faculdade de Odontologia de Bauru (FOB-USP) (ANEXO 1). A saliva não estimulada, foi coletada em placas de petri descartáveis (Jprolab, Presidente Prudente/SP, Brasil), estéreis e clarificada em tubos Eppendorf (Eppendorf do Brasil Ltda, São Paulo/SP, Brasil) por centrifugação a $10,000 \mathrm{~g}$ por 10 minutos a $4^{\circ} \mathrm{C}$.(MOURA et al., 2006) O sobrenadante foi coletado e dispensado em placas de cultura de células de 24 poços, onde os corpos de prova foram colocados em contato com a saliva humana por 30 
minutos a $37^{\circ} \mathrm{C}$, para a formação da película adquirida salivar. Após este período, os espécimes foram removidos dos poços, delicadamente lavados com água destilada para remover resíduos da saliva, deixados secar a temperatura ambiente por 30 minutos e então procedeu-se a mensuração do ângulo de contato.(SARDIN et al., 2004) (FIGURAS 6 - 7)

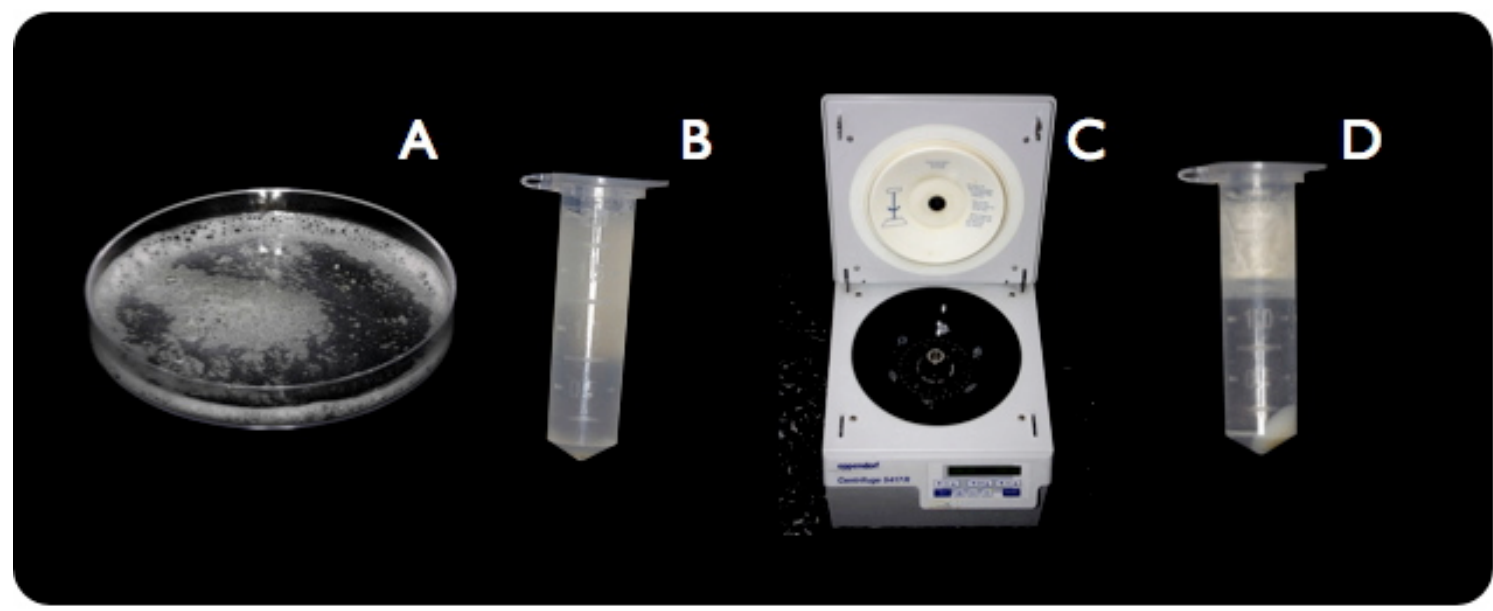

Figura 6: A: Coleta de saliva humana em placa de petri. B: Transferência de saliva humana a tubos de eppendorff 2 ml. C: Centrífuga. D: Saliva humana clarificada e formação de pellet.

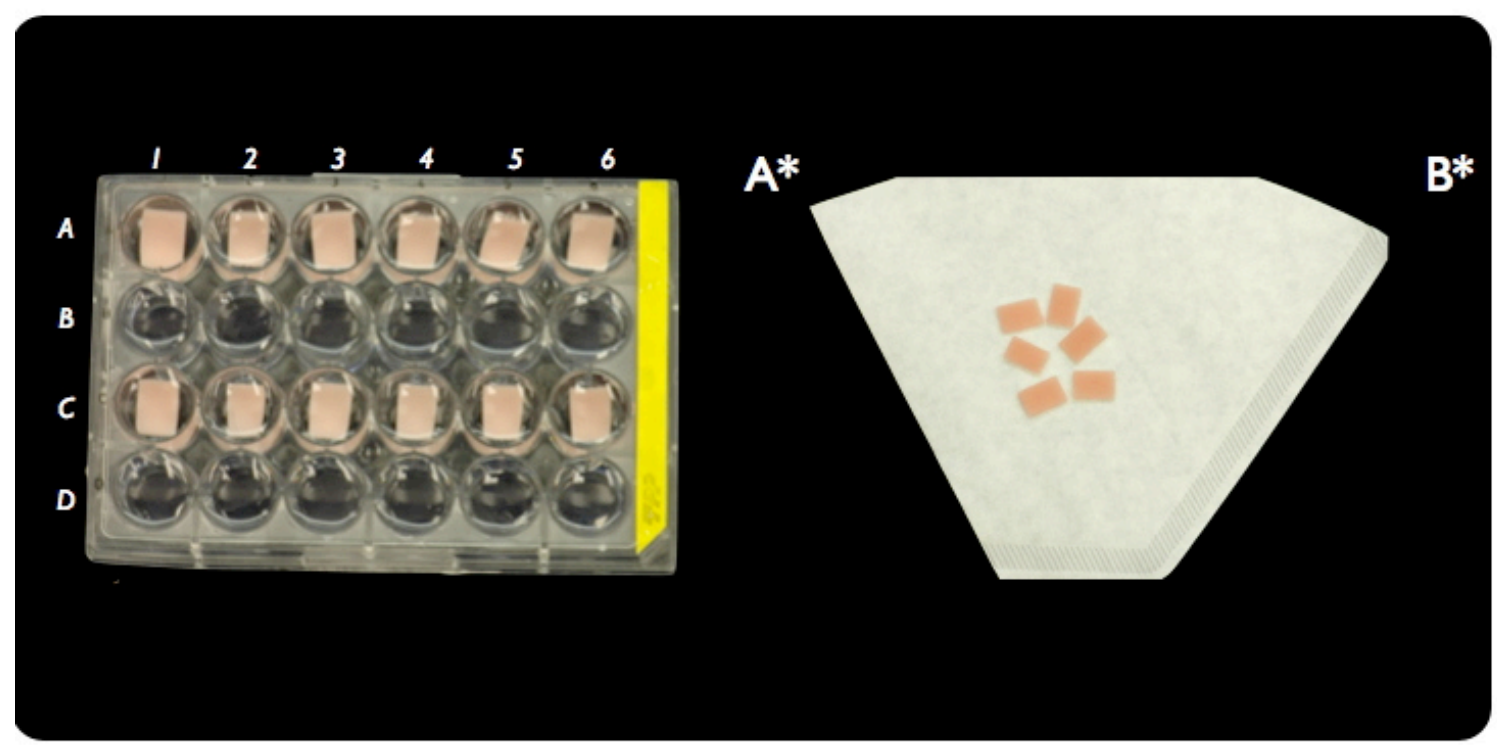

Figura 7: A*: Fila A e C destinadas a saliva humana clarificada. Filas B e D destinadas a lavagem suave em Água destilada. B: Secagem dos espécimes em papel absorvente. 


\subsubsection{Medição do ângulo de contato}

A determinação do ângulo de contato mediante o gotejamento de água Milli-Q sobre cada espécime foi realizada, antes e depois de 1,7,15 e 30 ciclos de desinfecções químicas com Hipoclorito de sódio 1\% e Gluconato de clorexidina 4\%.

$\mathrm{Na}$ finalização de cada um dos períodos avaliados (Inicial, 1, 7, 15, 30 ciclos), a mensuração foi realizada antes e depois dos espécimes serem expostos a saliva humana por 30 minutos a $37^{\circ} \mathrm{C}$. O corpo de prova foi colocado em uma base ajustável, a $0^{\circ}$ de inclinação e uma gota séssil (10 $\mu 1)$ de água Milli-Q (Billerica/MA, USA) à temperatura ambiente (COMBE; OWEN; HODGES, 2004), foi dispensada na superfície do corpo de prova com auxílio de uma micropipeta, procedimento realizado em 3 áreas diferentes do espécime. A captura da imagem da gota sobre o corpo de prova foi realizada com o uso da câmara fotográfica Nikon D70S, 6.1 Mega Pixels, equipada com lente telephoto AF Micro-Nikkor 105mm e Flash Nikon R1 Wireless close-up speedlight system, (Nikon inc. Melville/NY, USA). Todos os parâmetros: abertura do diafragma (F), resolução, distância, sensibilidade e velocidade foram previamente calibrados com fins de padronização dos registros fotográficos: Abertura f 29, Velocidade 1/250 ISO 500. A câmara fotográfica foi colocada em tripé ajustável para a facilitar a tomada fotográfica.(DE JONG; VAN PELT; ARENDS, 1982) Os ângulos de contato foram mensurados a partir da fotomacrografía do lado direito da gota. Uma tangente da gota foi desenhada desde o ponto de intersecção ar - água - resina e o ângulo de contato foi calculado a partir da linha da tangente e a superfície da resina.(DE JONG; VAN PELT; ARENDS, 1982; MOURA et al., 2006) (FIGURA 8).

Foram feitas três mensurações de ângulo de contato, em diferentes pontos de cada corpo de prova e a média desses valores foi obtida por meio do programa Autocad 2008 (Auto Desk, San Agustín, USA) (MOURA et al., 2006). A média obtida foi considerada como o ângulo de contato da superfície. 


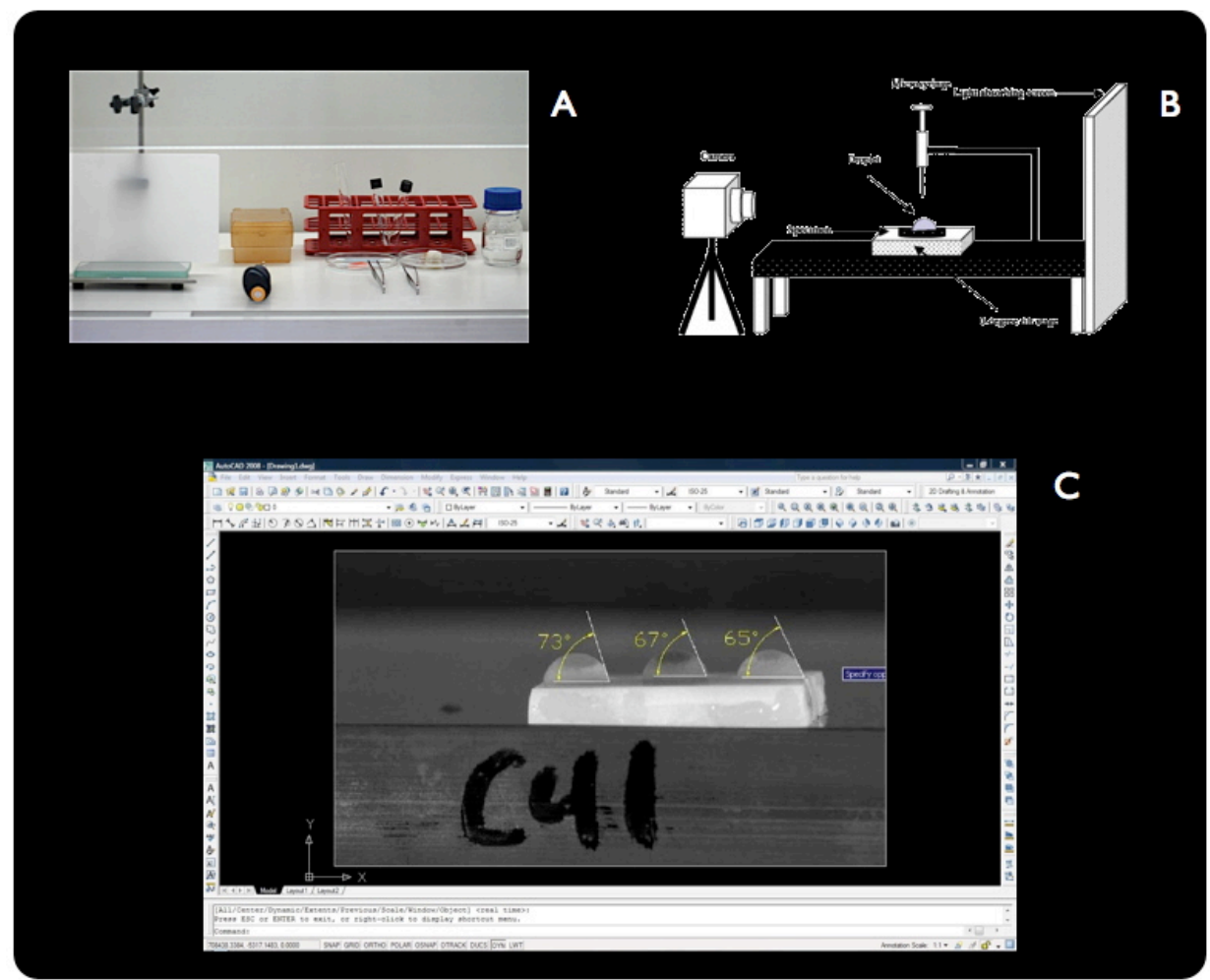

Figura 8: A: Dispositivo para tomada fotográfica. B:Esquema do dispositivo para tomada fotográfica Fonte:(YILDIRIM et al., 2006) C: Plataforma de trabalho do programa Autocad $2008 \AA$

\subsection{Experimento II: Colonização de $C$. albicans sobre resina acrílica} termopolimerizável após desinfecção em soluções químicas.

O processo de confecção dos espécimes utilizados no experimento II, foi similar ao utilizado no experimento I (Hidrofobicidade superficial), exceto algumas variações em formato, tamanho e método de obtenção do espécime.

\subsubsection{Confecção e inclusão dos padrões de silicona}

Para a confecção dos espécimes utilizados neste experimento $(n=180)$, inicialmente foram obtidos padrões de silicone por condensação de uso laboratorial Zetalabor (Hard 85 shore-A, Zhermack, Badia Polesine/RO, Italy). Esses padrões foram confeccionados a partir de uma matriz metálica, de forma retangular. Medindo 30 x 5 x $5 \mathrm{~mm}$. Foram seguidos os passos realizados no experimento I. (FIGURAS 9 e 10) 


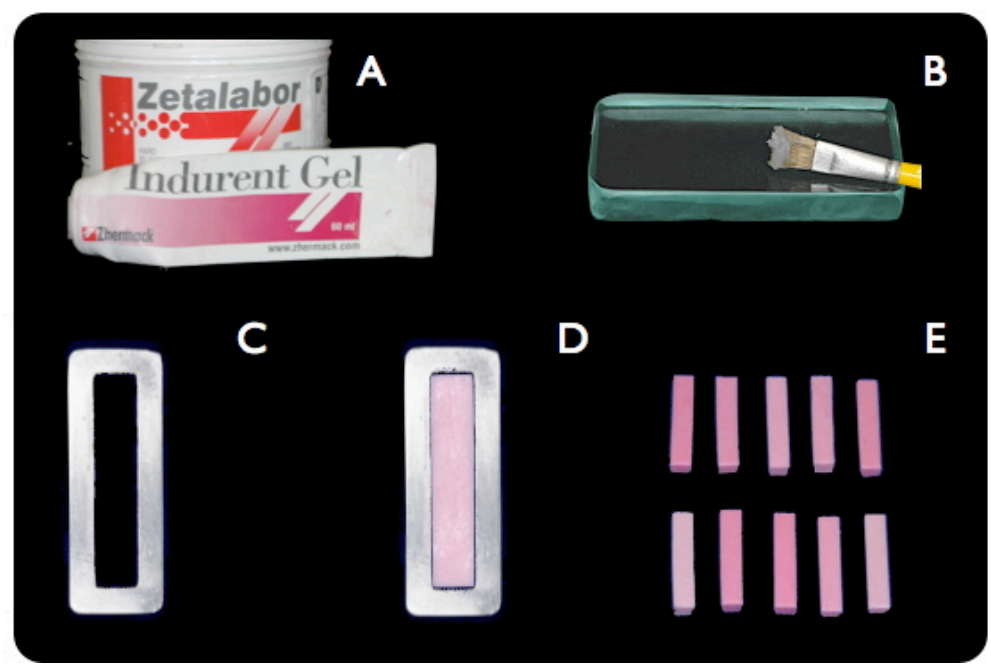

Figura 9: A: Silicona de condensação de uso laboratorial Zetalabor. B: Isolamento com Vaselina sólida das placas de vidro. C: Matriz metálica. D: Padrão de silicona após polimerização. E: Padrão de silicona finalizado.

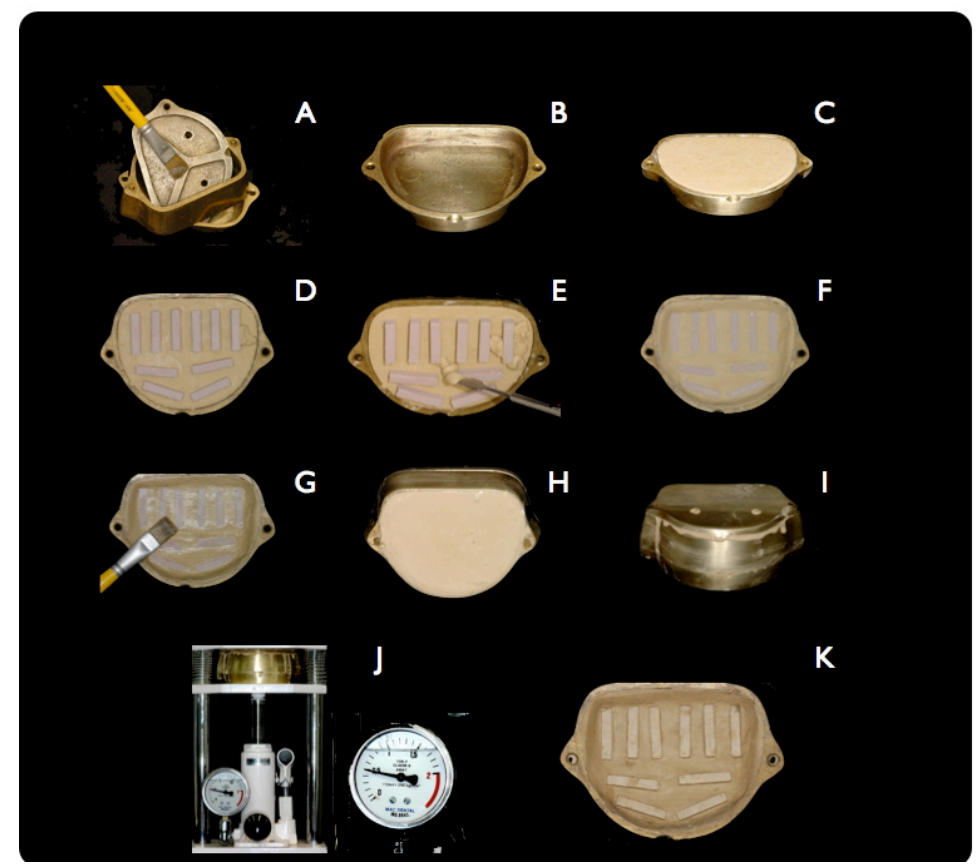

Figura 10: A: Isolamento da mufla, contra mufla e tampa com vaselina sólida. B: Mufla. C: Prenchimento da mufla com gesso tipo III D: Colocação dos padrões de silicona. E-F: Padrões de silicona fixados na mufla. G: Isolamento dos padrões de silicona com Cel-lac ${ }^{\circledR}$. H: Assentamento e prenchimento da contramufla com gesso tipo III. I: Colocação da tampa. J: Mufla na prensa hidráulica por 30 minutos. K: Remoção das matrizes de silicona e exame do molde de gesso. 


\subsubsection{Manipulação, inserção e termopolimerização da resina acrílica}

Para prensagem, foi utilizada a resina acrílica termopolimerizável Lucitone 550 incolor (Dentsply International INC., Chicago, IL, USA). Foram seguidos os passos realizados no experimento I. (FIGURA 11)

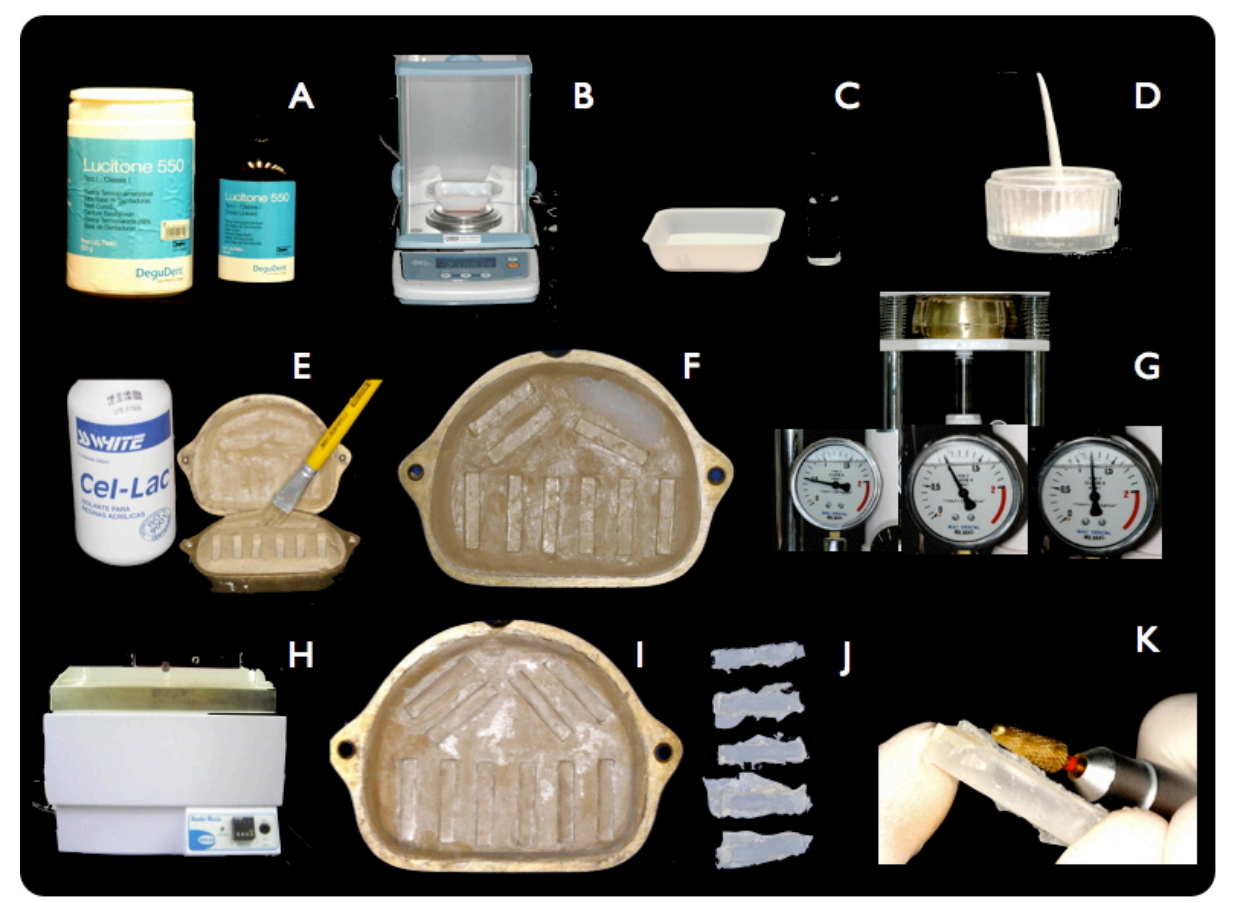

Figura 11: A: Lucitone 550 ®, Incolor. B: Pesagem do acrílico (21 g) em balança digital. C: Pó e liquido do acrílico D: Colocação do pó ao liquido do acrílico para mistura. E: Isolamento do molde de gesso com Cel-lac ${ }^{\circledR}$. F: Colocação do acrílico no molde de gesso na fase plástica. G: Colocação da mufla em prensa hidráulica com pressão de 0,5 1.0 e $1.5 \mathrm{Kg}$. H: Termopolimerizadora digital. I: Espécimes após concluído o ciclo de polimerização. J: Espécimes pré-tratados. K: Eliminação de excessos e rebarbas.

\subsubsection{Tratamento dos corpos de prova}

Posteriormente à demuflagem, Os excessos (rebarbas) dos pré- espécimes de resina acrílica foram desgastados com o auxílio de uma fresa de tungstênio e em seguida os pré-espécimes foram cortados, por meio de um disco diamantado (Extec dia. wafer blade 4"x.012 x 1⁄2 high concen., Erios, São Paulo, SP - Brasil), acoplado a uma máquina de corte de precisão (Isomet 1000, Buehler, USA), onde foi obtida uma lâmina de resina acrílica $(30 \times 5 \times 1 \mathrm{~mm})$. Para a fase de polimento todos os espécimes foram fixados em dispositivos de resina acrílica em forma de discos para permitir o uso de uma politriz 
metalográfica (marca Arotec, modelo APL 4 - Cotia/SP, Brasil), com dispositivo para polimentos múltiplos, utilizando lixa de silicone (3M, Sumaré/SP, Brasil) na granulação 600, aplicada sob refrigeração durante 4 minutos com carga de 107 gramas. As amostras foram limpas mediante imersão em água deionizada em ultra-som (Ultrasonic Cleaner Arotec, Cotia/SP, Brasil) por 20 minutos. Posteriormente foi conferida a rugosidade superficial $(\mathrm{Ra})$ inicial nos padrões de resina acrílica mediante a utilização do aparelho rugosímetro Hommel Tester T 1000 basic (Hommelwerke GmbH, ref. \# 240851, Schwenningen, Germany) onde se padronizou uma rugosidade superficial de $2 \mu \mathrm{m}$.

Após o polimento e mensuração da rugosidade superficial, cada lâmina foi seccionada em 5 partes iguais, originando os espécimes propriamente ditos (180), medindo 5 x 5 × $1 \mathrm{~mm}$ (LAMFON et al., 2003). Os 180 espécimes foram aleatoriamente divididos em grupos de 6, baseado em tipo de solução desinfetante, numero de ciclos avaliados (sub-períodos) e presença ou ausência de película adquirida salivar (TABELA 2).

Todos os espécimes foram acondicionados individualmente em poços de placas de cultura de células de 24 poços, contendo $2 \mathrm{~mL}$ água destilada por 12 horas a uma temperatura de $37^{\circ} \mathrm{C}$, procurando a eliminação de monômero residual (MOURA et al., 2006), em estufa (FANEM- controlador micro-processado modelo 502 C Orion- estufa de cultura- Guarulhos/SP- Brasil).

Em seguida, os espécimes foram deixados em ar livre para sua secagem e embalados individualmente para esterilização por meio de óxido de etileno (Acecil Central de esterilização comércio e indústria, Campinas/SP, Brasil) (MIMA et al., 2008; SILVA et al., 2006). (FIGURA 12) 


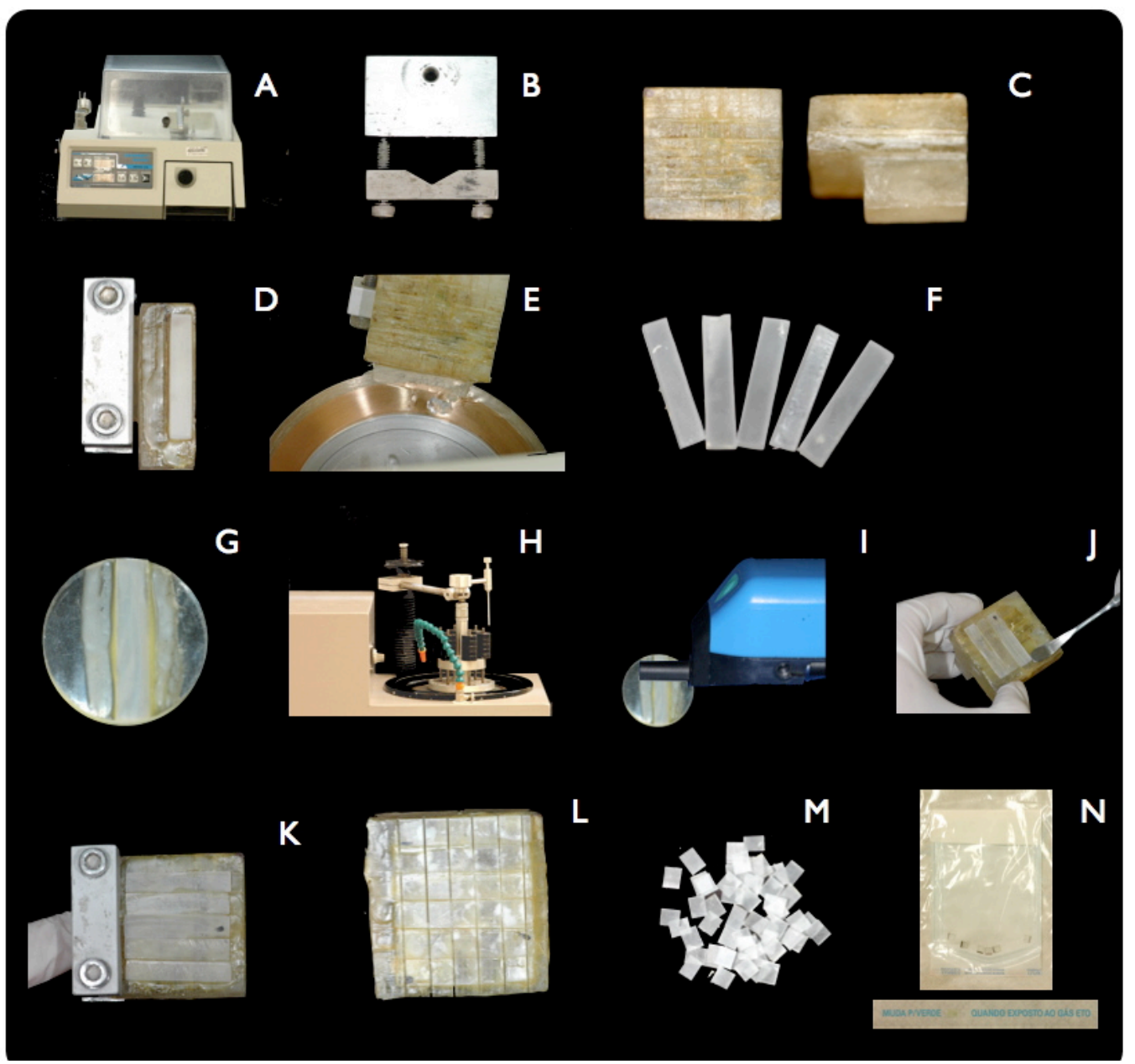

Figura 12: A: Máquina de corte de precisão digital B-C: Dispositivos para máquina de corte de precisão digital. D: Fixação do pré-espécime com cera pegajosa no dispositivo para máquina de corte. E: Corte longitudinal do préespécime. F: Lâminas de resina acrílica. G: Fixação das lâminas de resina com cera pegajosa no dispositivo circular para politríz metalográfica. H: Politriz Metalografica. I: Verificação da rugosidade superficial (Ra). J-K: Fixação das lâminas no dispositivo para máquina de corte. L: Corte dos espécimes (5x5x1 mm). M: Espécimes de resina acrílica. N: Espécimes esterilizados por meio de Óxido de Etileno. 


\subsubsection{Desinfecção em soluções químicas}

Os 180 corpos de prova foram divididos aleatoriamente em grupo controle e grupos experimentais (soluções químicas), os quais foram sub-divididos em grupos com e sem pré tratamento com saliva humana para formação de película adquirida salivar (TABELA 2)

Para cada grupo foram destinados 60 espécimes, 12 para cada sub-período avaliado, 6 para avaliação prévia a formação de película adquirida salivar e 6 para avaliação posterior a formação de película adquirida salivar.

Grupo 1 (Controle): Os corpos de prova $(n=6)$ foram imersos em água destilada por 10 minutos, simulando um ciclo de desinfecção; seguindo os procedimentos explicados no experimento I.

Grupo 2: Imersão em Hipoclorito de sódio a $1 \%$ por 10 minutos (PAVARINA et al., 2003) Os corpos de prova ( $\mathrm{n}=6)$ foram imersos em $2 \mathrm{ml}$ de uma solução de Hipoclorito de sódio a 1\% por 10 minutos. (Calendula Farmácia de Manipulação, Bauru, SP). Em seguida, os corpos de prova foram lavados em $2 \mathrm{ml}$ de água destilada por 1 minuto por 3 vezes, seguido de secagem em papel absorvente estéril para a posterior realização de um novo ciclo de desinfecção, até completar cada sub-período de avaliação. (FIGURA 13)

Grupo 3: Os corpos de prova $(n=6)$ foram imersos em Gluconato de clorexidina $4 \%$ (PAVARINA et al., 2003) por 10 minutos (Calendula Farmácia de Manipulação, Bauru,SP). Após foram repetidos os procedimentos de lavagem e secagem realizados no grupo 2. (FIGURA 13) 
Tabela 2: Divisão dos grupos avaliados no experimento II

\begin{tabular}{|c|c|c|c|}
\hline Grupos & $\mathbf{N}$ & $\begin{array}{l}\text { Tempo de } \\
\text { Desinfeç̧ăo }\end{array}$ & Intervalos Avallados \\
\hline Grupo Controle S- & 6 & 10 minutos & Inicial, 1, 7, 15, 30 \\
\hline Grupo Controle S+ & 6 & 10 minutos & Inicial, $1,7,15,30$ \\
\hline Hipoclorito de Sódio 1\% S- & 6 & 10 minutos & Inicial, $1,7,15,30$ \\
\hline Hipoclorito de Sodio $1 \%$ S+ & 6 & 10 minutos & Inicial, $1,7,15,30$ \\
\hline Gluconato de Clorexidina 4\% S- & 6 & 10 minutos & Inicial, $1,7,15,30$ \\
\hline Gluconato de Clorexidina $4 \%$ S+ & 6 & 10 minutos & Inicial, $1,7,15,30$ \\
\hline
\end{tabular}

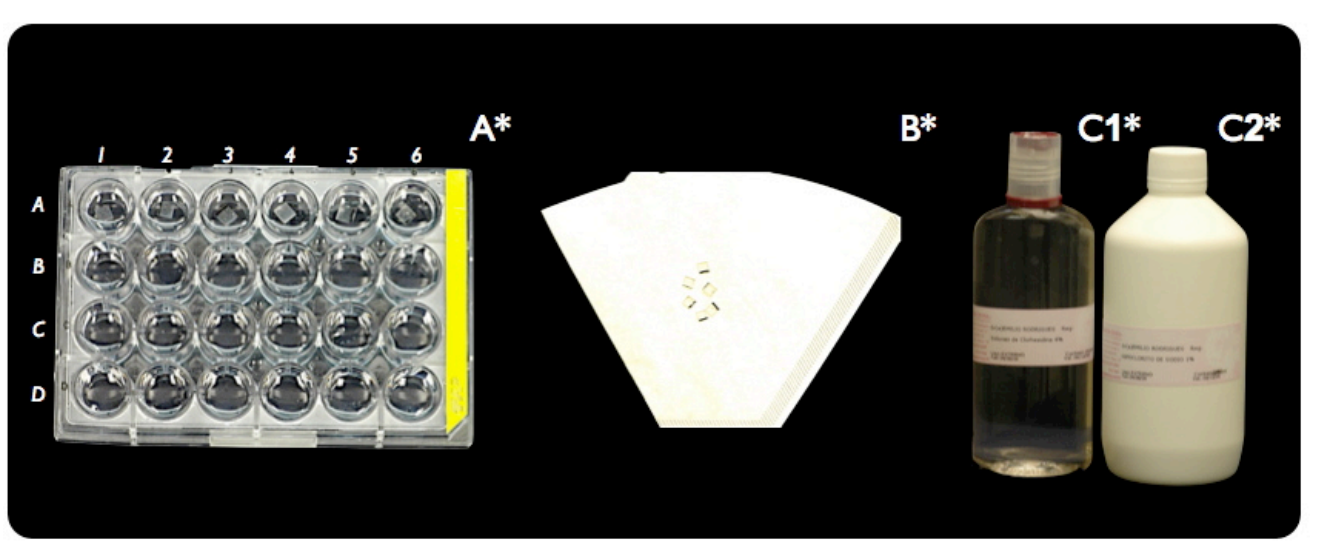

Figura 13: A*: Placa de cultura de células de 24 poços. Fila A (1-6): espécimes em solução desinfetante. Filas BCD (1-6): Poços destinados a lavagem dos espécimes com água destilada . B*: Secagem dos espécimes com papel absorvente estéril após cada ciclo de desinfecção. C1*: Gluconato de clorexidina 4\% (Calendula Farma). C2*:Hipoclorito de sódio 1\% (Calendula Farma 


\subsubsection{Formação de película adquirida salivar}

Após completados cada um dos sub-períodos dos ciclos de desinfecção avaliados, os grupos destinados a formação de película adquirida salivar ( $\mathrm{S}+$ ), foram pré-tratados com saliva humana clarificada por médio de centrifugação, simulando a influência da formação de película adquirida salivar na adesão de $C$. albicans sobre resina acrílica termopolimerizável Lucitone (Lucitone 550- Dentsply International INC, Chicago, IL, USA). Para a realização deste método, foram repetidos os procedimentos de formação de película adquirida salivar do experimento I. (FIGURA 14)

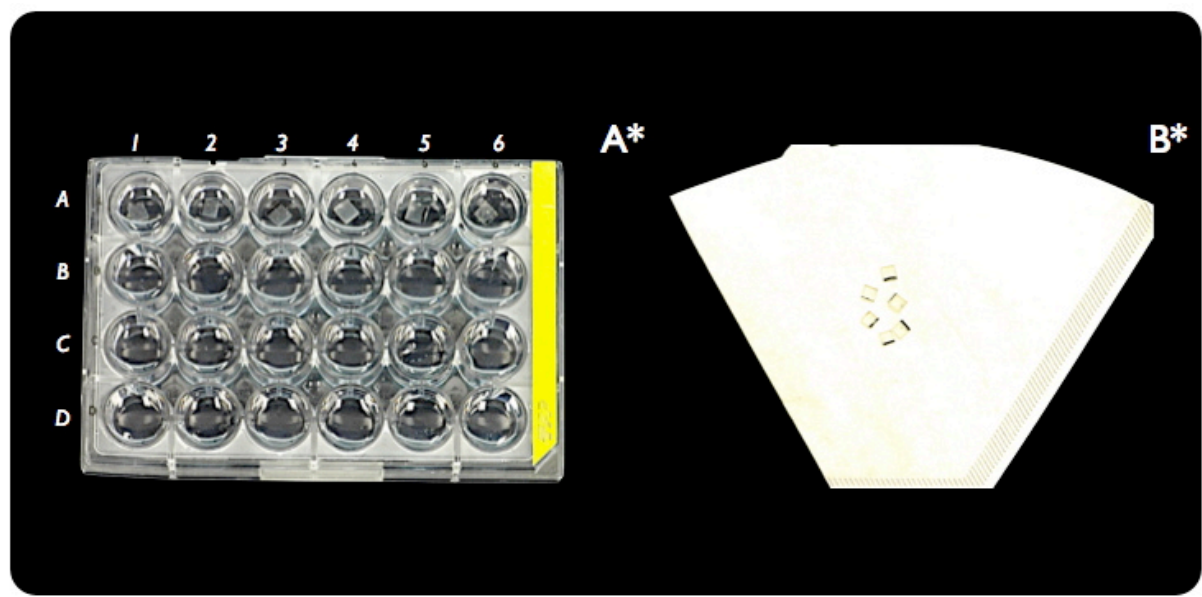

Figura 14: $A^{*}$ : filas $A$ e $C$ destinadas a saliva humana clarificada. Filas $B$ e $D$ destinadas a lavagem suave dos espécimes em água destilada. B: Secagem dos espécimes em papel absorvente.

\subsubsection{Fase de adesão de C. albicans}

Todos os ensaios microbiológicos foram realizados no laboratório de Microbiologia do Centro Integrado de Pesquisa-1 (CIP-1) da Faculdade de Odontologia de Bauru da Universidade de São Paulo, sempre em condições assépticas, em capela de fluxo laminar, previamente desinfetada com álcool $70^{\circ}$ e luz Ultra Violeta (UV) por 30 minutos.

A espécie C. albicans (ATCC 90028) foi reativada de sua cultura original contendo Tryptic Soy Broth (TSB) (Accumedia Manufacturers, Inc.Lansing, MI, USA) a $-80^{\circ} \mathrm{C}$, em $10 \mathrm{~mL}$ de meio de cultura TSB (CAMPANHA et al., 2007) com cloranfenicol (Quemicetina Succinato/ Carlo Erba ${ }^{\circledR}$, Milano, MI, Itália) (THERAUD et al., 2004), e incubada durante 24 horas a $37^{\circ} \mathrm{C}$ em estufa (Orion, Fanem, São Paulo/SP, Brasil), em condições aeróbicas. Após 24 horas foi executada a centrifugação (Centrifuge 5804R, 
Eppendorf do Brasil Ltda, São Paulo/SP, Brasil) da suspensão por 10 minutos, com velocidade de $5.000 \mathrm{rpm}$, a $22^{\circ} \mathrm{C}$, para separação dos microrganismos do sobrenadante. Os fungos isolados foram lavados 2 vezes em solução salina fosfatada (PBS) para remoção de impurezas, e o pellet final foi resuspenso em PBS. A seguir, a suspensão foi agitada por 15 segundos e a turbidez ajustada espectrofotometricamente (Pharmacia Biotech, Ultraspec 100, New Jersey, USA), a 600 nm, até atingir absorbância similar ao padrão 0,5 da escala Mc Farland. Este procedimento assegurou a preparação de uma suspensão celular com uma concentração final de $1.10^{7} \mathrm{cel} / \mathrm{mL}$ (CHANDRA et al., 2001) em TSB com cloranfenicol (Quemicetina Succinato/ Carlo Erba®, Milano, MI, Itália).

Após este período utilizando uma pinça estéril (S.S. White Art. Dentários LTDA, Rio de Janeiro/RJ, Brasil), todos os espécimes foram colocados individualmente em poços de uma placa de cultura de tecidos de 24 poços (TPP, Trasadingen, Switzerland), no qual foi dispensado $2 \mathrm{~mL}$ da suspensão celular, através de pipetas de precisão e ponteira descartáveis, deixando os corpos-de-prova totalmente submersos. Todos os espécimes foram deixados em cultura com C. albicans por 90 minutos em estufa a $37^{\circ} \mathrm{C}$ sob agitação (THEIN; SAMARANAYAKE; SAMARANAYAKE, 2007). Cessado este tempo, os corpos-de-prova foram individualmente e suavemente lavados em $2 \mathrm{~mL}$ de PBS por duas vezes (HAWSER; DOUGLAS, 1994) para garantir a remoção de células não aderidas ao substrato (KUHN et al., 2002). A seguir, os corpos-de-prova foram preparados para análise em microscopia de fluorescência. (FIGURA 15)

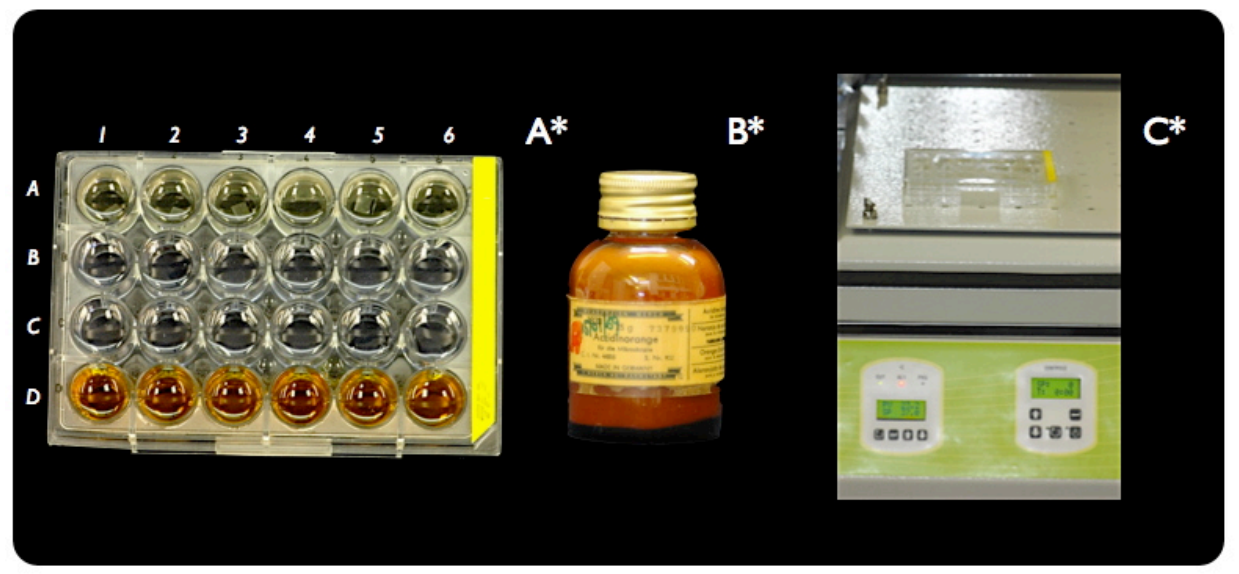

Figura 15: A*: Placa de cultura de células de 24 poços. Fila A (1-6): Espécimes em fase de adesão de C. albicans (TSB + C. albicans 90028). Filas BC (1-6): Poços destinados a lavagem suave dos espécimes com água destilada . Filera D (1-6): Solução flourocromo Laranja de acridina. B*: Fluorocromo Laranja de acridina. $C^{*}$ : Estufa incubadora com agitação (75 rpm, 90 minutos) 


\subsubsection{Processamento dos espécimes para microscopia fluorescente}

Cada corpo-de-prova foi transferido para um poço da placa de cultura de tecidos de 24 poços, contendo $1 \mathrm{~mL}$ do fluorocromo Laranja de acridina (Reagenzien, Merck, Darmstadt, Germany). A concentração do corante $1.25 \mu \mathrm{g} / 10 \mathrm{ml}$ PBS, foi ajustada durante os ensaios piloto, de modo a proporcionar um melhor contraste entre as células fúngicas e a resina acrílica. $\mathrm{Na}$ seqüência, foram aguardados 20 minutos para que houvesse a difusão do fluorocromo nas células aderidas (JIN et al., 2005). Este processo foi realizado na ausência de luz a $37^{\circ} \mathrm{C}$, de acordo com as orientações do fabricante, seguido por uma lavagem em PBS por 5 minutos para eliminação de excesso do corante.

Imediatamente após o período de lavagem, 2 espécimes foram cuidadosamente montados em lâmina e lamínula de vidro para microscopia, para posterior análise das células aderidas, mediante a utilização do microscópio fluorescente Axiostar Plus Carl Zeiss (Carl Zeiss, Göttingen, Germany). A objetiva usada foi a lente de 40x de aumento . imediatamente à leitura no microscópio de fluorescência, os espécimes eram descartados, diferente ao ensaio realizado no experimento I, onde os espécimes não foram descartados até completar o período final de avaliação (30 ciclos de desinfecção). (FIGURA 16) 


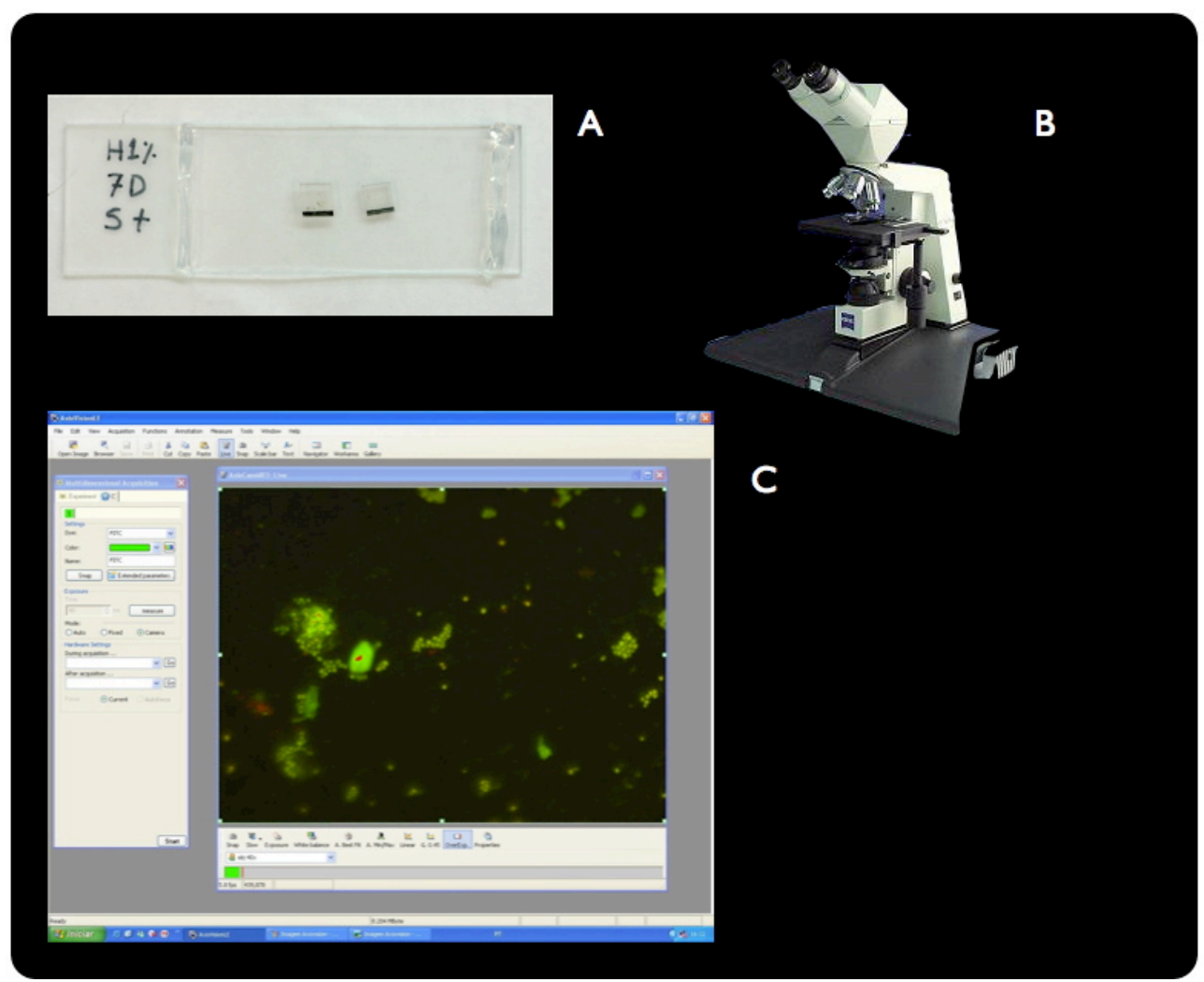

Figura 16: A: Lâmina de microscopia montada para posterior analise em microscópio Fluorescente. B: Microscópio Fluorescente. C: Plataforma de trabalho do programa axiovision Carl Zeiss.

\subsubsection{Análise dos espécimes no microscópio fluorescente}

A aquisição das imagens foi realizada de maneira padronizada em 6 diferentes campos (SMITH; HUNTER, 2008), de acordo com a figura 17, a fim de que não houvesse a possibilidade de análise de um mesmo campo repetidas vezes.

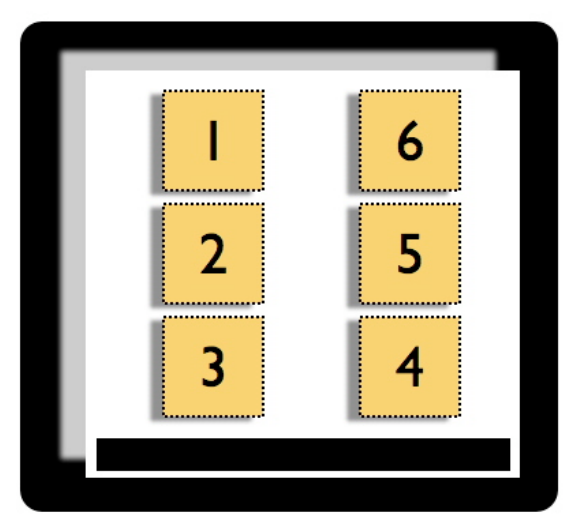

Figura 17: Seqüência padrão de análise dos 6 campos dos espécimes no microscópio fluorescente. 
Para a análise das células aderidas, foi realizada a tomada fotográfica de cada um dos campos selecionados. O programa utilizado para a aquisição e processamento das imagens digitais foi o Axiovision Carl Zeiss (Carl Zeiss, Göttingen, Germany).

A contagem dos microrganismos em cada campo de cada corpo-de-prova foi realizada através do programa ImageJ 1.38x (National Institutes of Health, EUA) (PEREIRA-CENCI et al., 2008), que proporcionou a identificação e a contagem das células aderidas. Os valores médios de cada grupo encontrados foram catalogados para posterior análise estatística. (FIGURA 18)

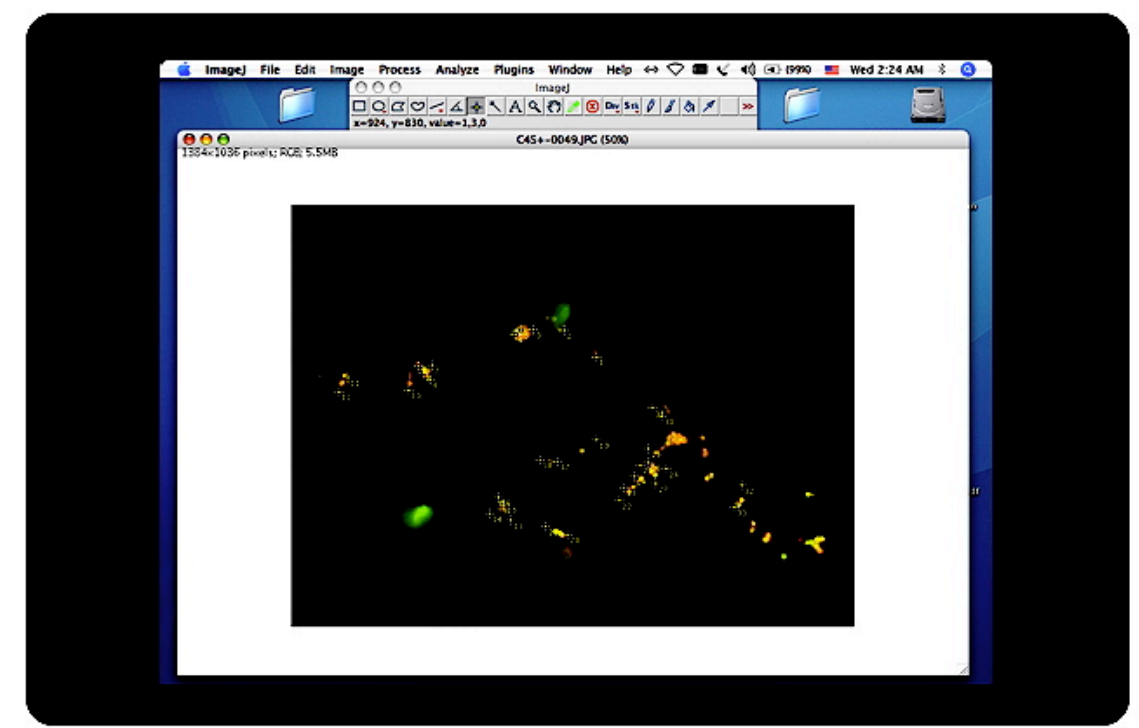

Figura 18: Plataforma de trabalho do programa Image J $1.38 X$.

\subsection{Análise estatística}

Para o experimento I, os valores médios das mensurações de ângulo de contato foram analisados através do teste paramétrico ANOVA para medidas repetidas (Repeated measures $A N O V A$ ), seguido do teste de Tukey para as comparações entre os grupos. Para comparação entre os grupos com e sem saliva foi utilizado o teste T-student.

Para o experimento II, os valores médios de adesão celular de C. albicans foram analisados através do teste não paramétrico Kruskall Wallis, seguido do teste de Dunn's para comparações entre grupos.

Para correlação das variáveis hidrofobicidade superficial e adesão de C. albicans, Fo utilizado o teste de Pearson. 


\section{RESULTADOS}

\subsection{Experimento I: Hidrofobicidade superficial de Resina acrilica termopolimerizável após desinfecção em soluções químicas.}

\subsubsection{Grupo Controle}

$\mathrm{Na}$ análise através da mensuração do ângulo de contato do grupo controle imerso em água destilada, foi possível observar a característica hidrofílica da resina acrílica termopolimerizável, antes da formação da película adquirida salivar, mediante ângulos de contatos menores de $90^{\circ}$ (FIGURA 19) durante os 30 de desinfecção química avaliados. Foram observados valores de ângulo de contato entre $57.33^{\circ} \pm 3.53$ e $42.17^{\circ} \pm 4.43$. observando-se diferença estatisticamente significante exclusivamente entre o período inicial e ciclo 1. Entre os demais períodos, não se observou diferença estatística. (TABELA 3) (GRÁFICO 1)

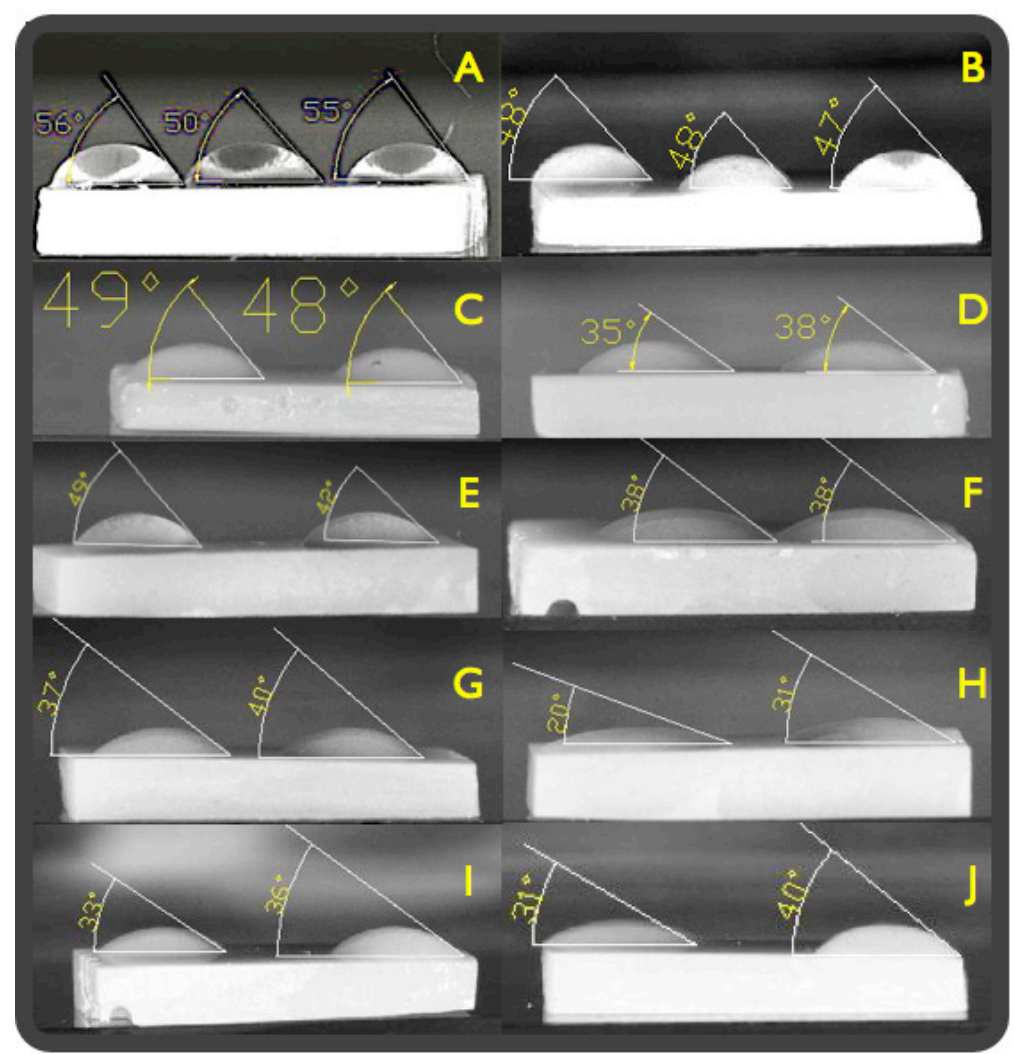

Figura 19: A-B: Imagem de ângulo de contato grupo controle inicial pré e pós película adquirida. C-D: Imagem após 1 ciclo pré e pós película adquirida. E-F Imagem de ângulo de contato após 7 ciclos pré e pós película adquirida. G-H: Imagem de ângulo de contato após 15 ciclos pré e pós película adquirida. I-J: Imagem de ângulo de contato após 30 ciclos pré e pós película adquirida. Nas imagens onde aparecem duas mensurações, uma terceira mensuração foi realizada. 
Após a formação da película adquirida salivar (FIGURA 19), observaram-se valores entre $28.67^{\circ} \pm 2.87$ e $43.61^{\circ} \pm 4.80$. O valor inicial apresentou diferença estatística significante em relação aos demais períodos avaliados. O ciclo 30 apresentou diferença estatística significante com os ciclos 7 e 15, não apresentando diferença com o ciclo 1 . Os períodos 1,7 e 15 ciclos foram similares entre si, não apresentando diferença estatística significante. (TABELA 4) (GRÁFICO 2)

Comparando os valores pré e pós a formação da película adquirida salivar, houve uma diminuição nos valores de ângulo de contato na resina acrílica termopolimerizável, sendo que esses valores foram significantes em todos os períodos avaliados, exceto no $1 \mathrm{e}$ 30 ciclos, demonstrando variabilidade no processo de absorção protéica seletiva por parte do substrato. (TABELA 5) (GRÁFICO 3)

A Tabela 3 representa a média e o desvio-padrão dos valores de ângulo de contato de cada grupo nos diferentes tempos prévio à formação de película adquirida salivar.

\begin{tabular}{c|c|c|c}
\hline Ciclos de desinfecção & Controle & \multicolumn{2}{c}{ Soluções desinfetantes } \\
\hline & Agua Destilada & Hipoclorito de Sódio 1\% & Gluconato de Clorexidina 4\% \\
\hline Inicial & $57.33^{\circ} \pm 3.53 \mathrm{aA}$ & $59.06^{\circ} \pm 2.28 \mathrm{aA}$ & $57.44^{\circ} \pm 5.68 \mathrm{aA}$ \\
\hline 1 ciclo & $41.61^{\circ} \pm 4.58 \mathrm{bA}$ & $59.3^{\circ} \pm 4.09 \mathrm{abB}$ & $49.67^{\circ} \pm 2.15 \mathrm{cC}$ \\
\hline 7 ciclos & $45.39^{\circ} \pm 3.5 \circ \mathrm{bA}$ & $67.89^{\circ} \pm 3.69 \mathrm{cB}$ & $45.61^{\circ} \pm 5.39 \mathrm{cA}$ \\
\hline 15 ciclos & $44.50^{\circ} \pm 6.25 \mathrm{bA}$ & $72.44^{\circ} \pm 3.42 \mathrm{cB}$ & $42.33^{\circ} \pm 5.82 \mathrm{bcA}$ \\
\hline 30 ciclos & $42.17^{\circ} \pm 4.43 \mathrm{bA}$ & $66.61^{\circ} \pm 2.59 \mathrm{bcB}$ & $38.06^{\circ} \pm 5.78 \mathrm{bA}$ \\
\hline
\end{tabular}

Tempos com a mesma letra minúscula em cada coluna e soluções com a mesma letra maiúscula em cada fila, não possuem diferença estatística significante entre si. 
O Gráfico 1 representa a média dos valores de ângulo de contato de cada grupo nos diferentes ciclos prévio à formação de película adquirida salivar

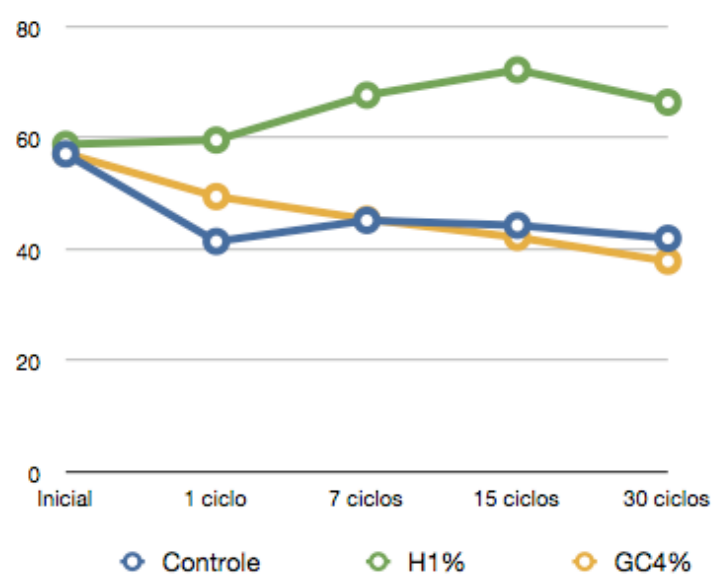

H1\% - Grupo Hipoclorito de sódio 1\% GC4 - Grupo Gluconato de clorexidina 4\%

\subsubsection{Grupo Hipoclorito de sódio 1\%}

$\mathrm{Na}$ análise através da mensuração do ângulo de contato do grupo experimental, imerso em Hipoclorito de sódio 1\%, também foi possível observar a característica hidrofílica da resina acrílica termopolimerizável, antes e depois da formação da película adquirida salivar, mediante ângulos de contatos menores que $90^{\circ}$ (FIGURA 20) durante os períodos de avaliação. Reportaram-se valores de ângulo de contato entre $59.06^{\circ} \pm 2.28$ e $66.61^{\circ} \pm 2.59$. Analisando os valores reportados prévio a formação da película adquirida salivar (FIGURA 20), observou-se que o valor inicial teve diferença estatisticamente significante com os valores referentes aos ciclos 7, 15 e 30, os quais não apresentaram diferença estatística entre si. O primeiro ciclo não apresentou diferença estatística com o valor inicial e o ciclo 30. (TABELA 3) (GRÁFICO 1) 


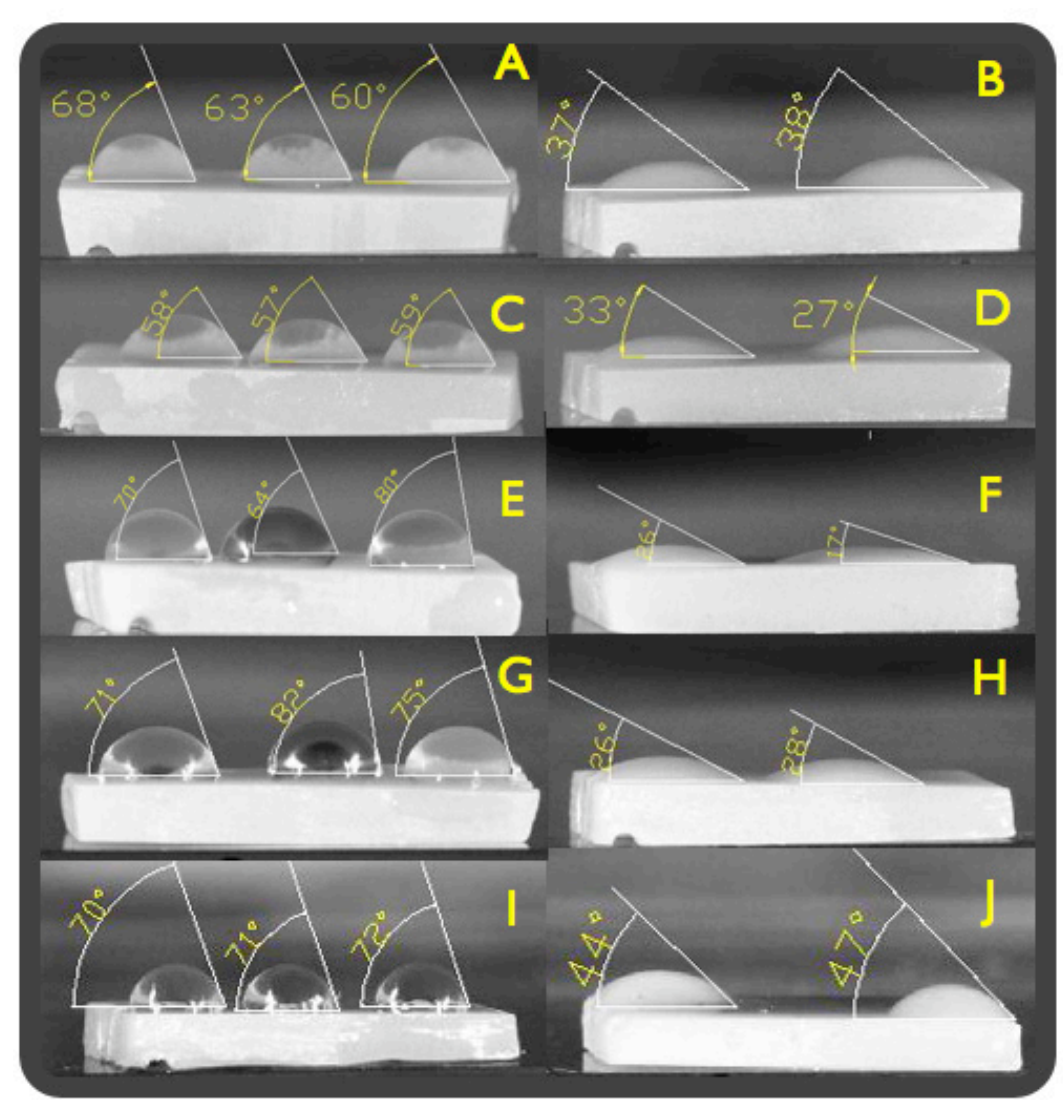

Figura 20: A-B: Imagem de ângulo de contato grupo H1\% inicial pré e pós película adquirida. C-D: Imagem após 1 ciclo pré e pós película adquirida. E-F Imagem de ângulo de contato após 7 ciclos pré e pós película adquirida. G-H: Imagem de ângulo de contato após 15 ciclos pré e pós película adquirida. I-J: Imagem de ângulo de contato após 30 ciclos pré e pós película adquirida. Nas imagens onde aparecem duas mensurações, uma terceira mensuração foi realizada.

Após a formação da película adquirida salivar (FIGURA 20), observou-se que o resultado referente ao ciclo 7 apresentou diferença estatística em relação aos períodos inicial e 30 ciclos. Os períodos inicial, 1,15 e 30 ciclos foram similares entre si, não apresentando diferença estatística significante. (TABELA 4) (GRÁFICO 2)

Comparando os valores de ângulo de contato, pré e pós formação de película adquirida salivar, observou-se uma diminuição estatisticamente significante em todos os períodos avaliados. (TABELA 5) (GRÁFICO 4) 
A Tabela 4 representa a média e o desvio-padrão dos valores de ângulo de contato de cada grupo nos diferentes ciclos, posterior à formação de película adquirida salivar.

\begin{tabular}{c|c|c|c}
\hline Ciclos de desinfecção & Controle & \multicolumn{2}{|c}{ Soluções desinfetantes } \\
\hline & Agua Destilada & Hipoclorito de Sódio 1\% & Gluconato de Clorexidina 4\% \\
\hline Inicial & $28.67^{\circ} \pm 2.87 \mathrm{acA}$ & $31.89^{\circ} \pm 4.11 \mathrm{aA}$ & $32.78^{\circ} \pm 5.79 \mathrm{bA}$ \\
\hline 1 ciclo & $36.06^{\circ} \pm 3.86 \mathrm{bcA}$ & $30.67^{\circ} \pm 3.45 \mathrm{abA}$ & $44.00^{\circ} \pm 4.3 \circ \mathrm{aB}$ \\
\hline 7 ciclos & $32.67^{\circ} \pm 4.64 \mathrm{cA}$ & $22.89^{\circ} \pm 4.47 \mathrm{bB}$ & $31.39^{\circ} \pm 5.18 \mathrm{bA}$ \\
\hline 15 ciclos & $31.28^{\circ} \pm 6.44 \mathrm{CA}$ & $28.28^{\circ} \pm 3.76 \mathrm{abA}$ & $30.17^{\circ} \pm 5.88 \mathrm{bA}$ \\
\hline 30 ciclos & $43.61^{\circ} \pm 4.8 \mathrm{bA}$ & $33.8^{\circ} \pm 4.59 \mathrm{aB}$ & $37.00^{\circ} \pm 5.42 \mathrm{abB}$ \\
\hline
\end{tabular}

Tempos com a mesma letra minúscula em cada coluna e soluções com a mesma letra maiúscula em cada fila, não possuem diferença estatística significante entre si.

O Gráfico 2 representa a média dos valores de ângulo de contato de cada grupo nos diferentes ciclos, posterior à formação de película adquirida salivar.

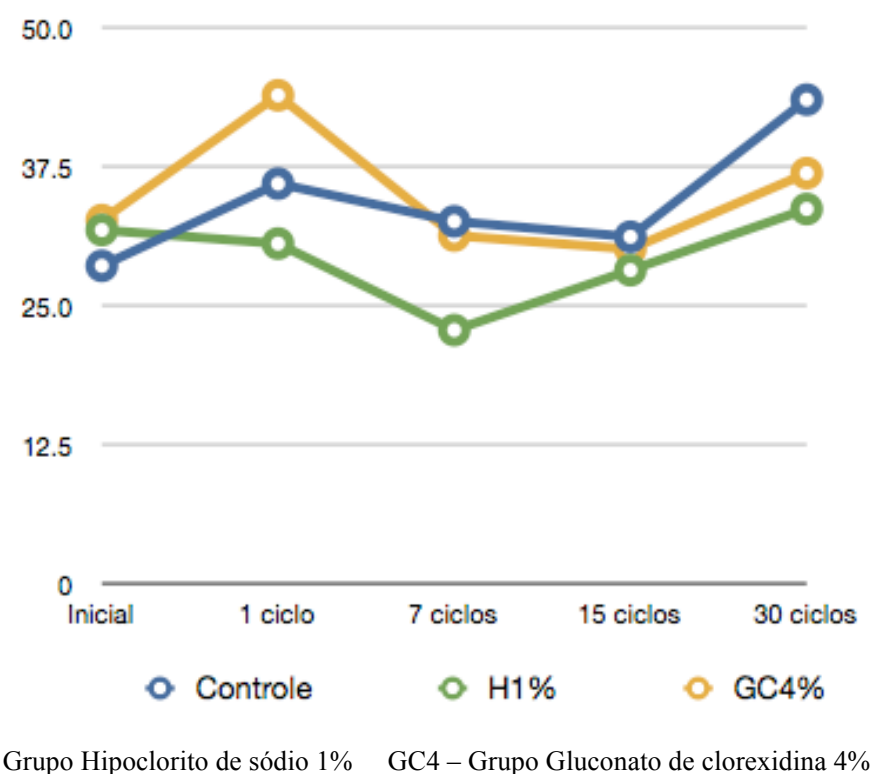

H1\% - Grupo Hipoclorito de sódio 1\% GC4 - Grupo Gluconato de clorexidina 4\% 


\subsubsection{Grupo Gluconato de clorexidina 4\%}

$\mathrm{Na}$ análise através da mensuração do ângulo de contato do grupo experimental, imerso em Gluconato de clorexidina 4\%, foi possível observar a característica hidrofílica da resina acrílica termopolimerizável antes e depois da formação da película adquirida salivar, mediante ângulos de contatos menores de $90^{\circ}$ através dos ciclos de desinfecção química avaliados. Reportaram-se valores de ângulo de contato entre $57.44^{\circ} \pm 5.68 \mathrm{e}$ $38.06^{\circ} \pm 5.78$. Analisando-se os valores reportados prévio a formação da película adquirida salivar (FIGURA 21), pode-se observar que o valor inicial teve diferença estatisticamente significante comparativamente aos valores referentes aos outros ciclos avaliados. Os ciclos 1, 7 e 15 não apresentaram diferenças estatisticamente significante entre si; e o ciclo 15 não apresentou diferença estaticamente significante com o ciclo 30. (TABELA 3) (GRÁFICO 1)

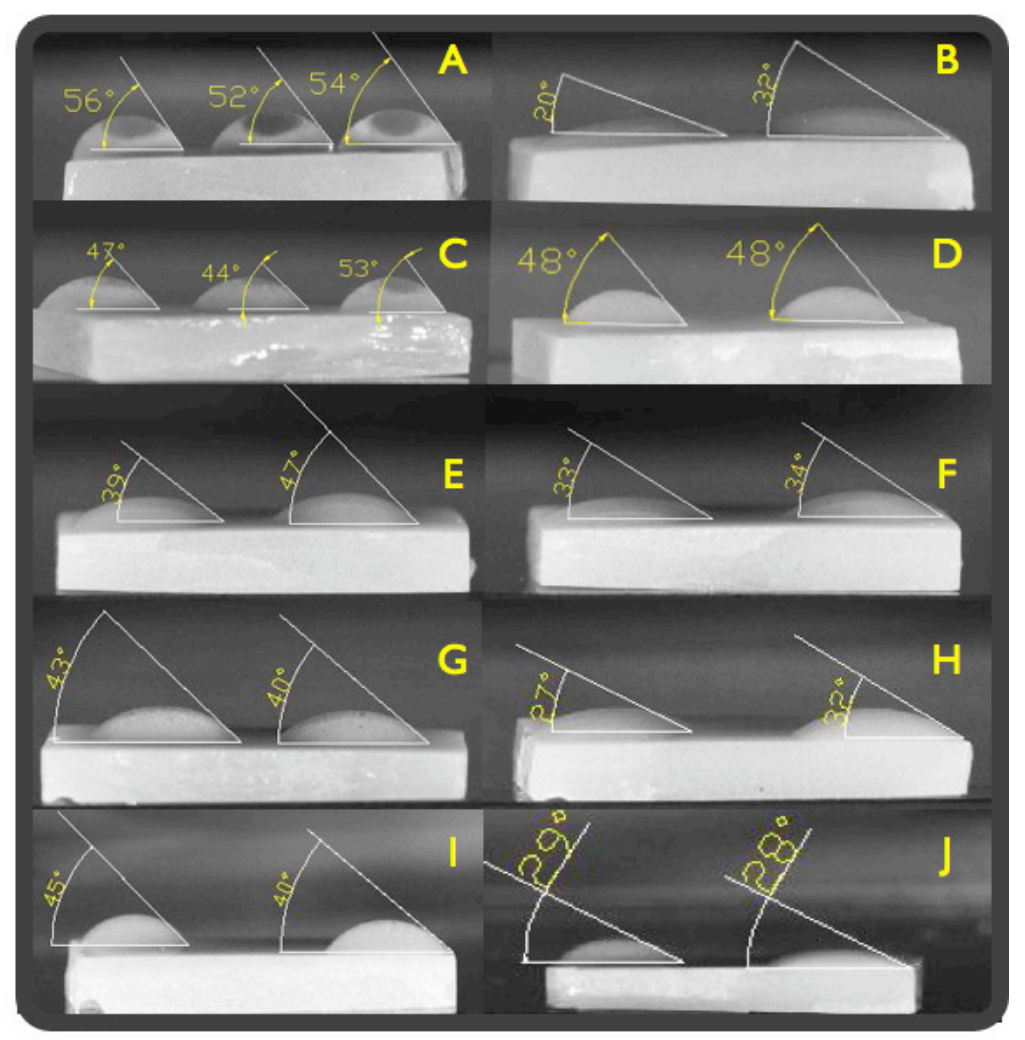

Figura 21: A-B: Imagem de ângulo de contato grupo GC4\% inicial pré e pós película adquirida. C-D: Imagem após 1 ciclo pré e pós película adquirida. E-F Imagem de ângulo de contato após 7 ciclos pré e pós película adquirida. G-H: Imagem de ângulo de contato após 15 ciclos pré e pós película adquirida. I-J: Imagem de ângulo de contato após 30 ciclos pré e pós película adquirida. Nas imagens onde aparecem duas mensurações, uma terceira mensuração foi realizada. 
Após a formação da película adquirida salivar (FIGURA 21), observaram-se valores entre $30.17 \pm 5.88$ e $44.00 \pm 4.30$. O resultado referente ao ciclo 1 apresentou diferença estatística significante com os ciclos inicial, 7 e 15 ciclos, não apresentado diferença estatística significante com o ciclo 30. Os ciclos inicial, 7, 15 e 30 foram similares entre si, não apresentando diferença estatística significante. (TABELA 4) (GRÁFICO 2)

Comparando os valores de ângulo de contato, pré e pós formação da película adquirida salivar, observou-se uma diminuição estatisticamente significante em todos os ciclos avaliados, exceto para o ciclo 30. (TABELA 5) (GRÁFICO 5)

\subsubsection{Comparação dos desinfetantes prévios à formação de película adquirida salivar}

Comparando os valores obtidos dos grupos controle e experimentais previamente à formação de película adquirida salivar nos diferentes ciclos, houve uma diferença estatística significante entre o grupo controle e o Gluconato de clorexidina 4\% no ciclo 1 , não se encontrando diferença estatística nos outros períodos. Comparando o grupo controle e o Gluconato de clorexidina 4\% com a solução de Hipoclorito de sódio 1\%, observou-se diferença estatística em todos os períodos, exceto no ciclo inicial. (TABELA 3) (GRÁFICO 1)

\subsubsection{Comparação dos desinfetantes posterior à formação de película adquirida salivar}

Comparando os valores obtidos dos grupos controle e experimentais posterior à formação de película adquirida salivar nos diferentes ciclos, pode-se observar diferença estatística significante entre o grupo controle e o Gluconato de clorexidina 4\% no 1 e 30 ciclos, não se verificando diferença estatística nos outros períodos. Comparando o grupo controle com a solução de Hipoclorito de sódio 1\%, observou-se diferença estatística nos períodos 7 e 30 ciclos. Comparando as soluções desinfetantes Hipoclorito de sódio 1\% e 
Gluconato de clorexidina 4\%, observou-se diferença estatística nos períodos 1 e 7 ciclos. (TABELA 4) (GRÁFICO 2)

A Tabela 5 representa a média e o desvio-padrão dos valores de ângulo de contato de cada grupo nos diferentes ciclos prévio e posterior à formação de película adquirida salivar.

\begin{tabular}{c|c|c|c}
\hline Desinfetante & Ciclos & S- & S+ \\
\hline & & & \\
\hline & Inicial & $57.33^{\circ} \pm 3.53^{*}$ & $28.67^{\circ} \pm 2.87^{*}$ \\
\hline & 1 ciclo & $41.61^{\circ} \pm 4 \cdot 58$ & $36.06^{\circ} \pm 3.86$ \\
\hline & 7 ciclos & $45.39^{\circ} \pm 3.50^{*}$ & $32.67^{\circ} \pm 4.64^{*}$ \\
\hline & 15 ciclos & $44.50^{\circ} \pm 6.25^{*}$ & $31.28^{\circ} \pm 6.44^{*}$ \\
\hline & 30 ciclos & $42.17^{\circ} \pm 4.43$ & $43.61^{\circ} \pm 4.80$ \\
\hline & & & \\
\hline Hipoclorito de Sódio 1\% & 7 ciclos & $67.89^{\circ} \pm 3.69^{*}$ & $22.89^{\circ} \pm 4.47^{*}$ \\
\hline & 15 ciclos & $72.44^{\circ} \pm 3.42^{*}$ & $28.28^{\circ} \pm 3.76^{*}$ \\
\hline & 30 ciclos & $66.61^{\circ} \pm 2.59^{*}$ & $33.78^{\circ} \pm 4.59^{*}$ \\
\hline & & & $31.89^{\circ} \pm 4.11^{*}$ \\
\hline & Inicial & $57.44^{\circ} \pm 5.68^{*}$ & $32.78^{\circ} \pm 5.79^{*}$ \\
\hline & 1 ciclo & $49.67^{\circ} \pm 2.15^{*}$ & $44.00^{\circ} \pm 4.30^{*}$ \\
\hline & 7 ciclos & $45.61^{\circ} \pm 5.39^{*}$ & $31.39^{\circ} \pm 5.18^{*}$ \\
\hline & 15 ciclos & $42.33^{\circ} \pm 5.82^{*}$ & $30.17^{\circ} \pm 5.88^{*}$ \\
\hline & 30 ciclos & $38.06^{\circ} \pm 5.78$ & $37.00^{\circ} \pm 5.42$ \\
\hline & & & $30.67^{\circ} \pm 3.45^{*}$ \\
\hline & & &
\end{tabular}

Valores com asterisco $(*)$ em cada solução e tempo testado possuem diferença estatisticamente significante. 
O Gráfico 3 representa a média dos valores de ângulo de contato do grupo controle nos diferentes ciclos prévio e posterior formação de película adquirida salivar

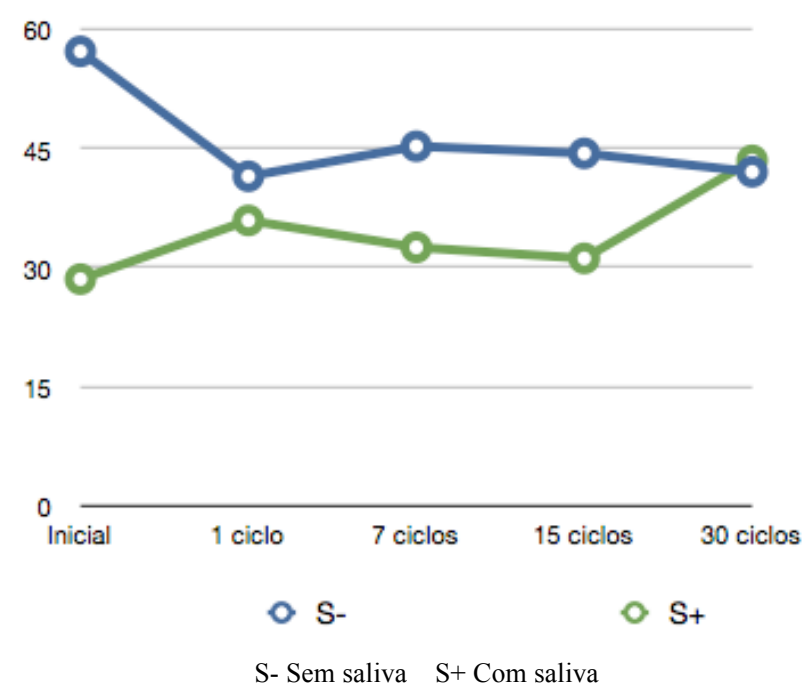

O Gráfico 4 representa a média dos valores de ângulo de contato do grupo Hipoclorito de sódio $1 \%$, nos diferentes tempos prévio e posterior à formação de película adquirida salivar.

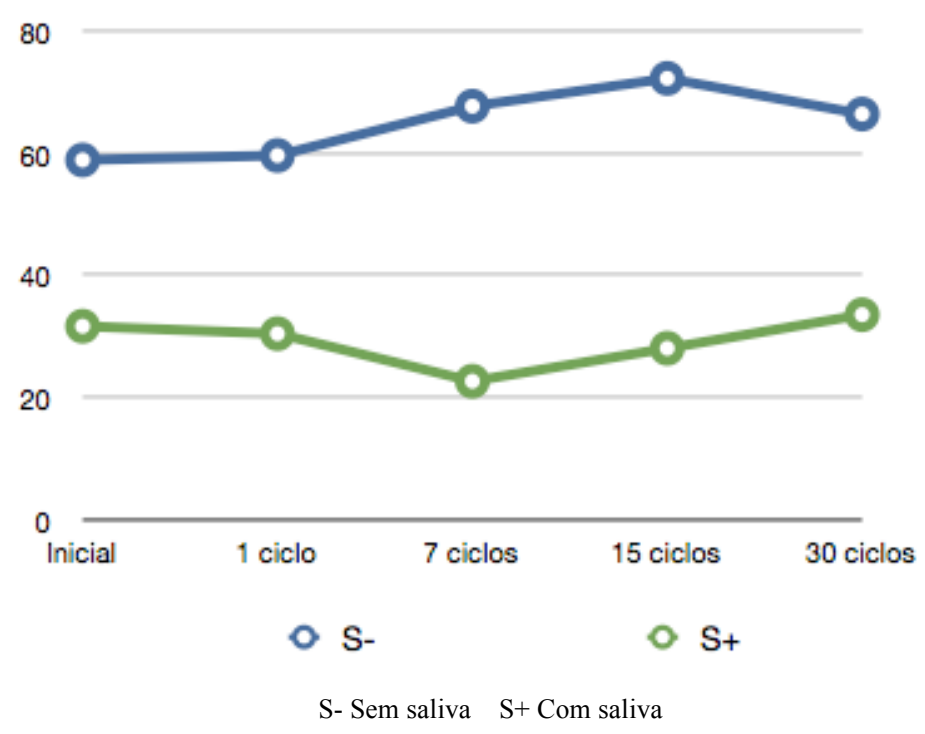


O Gráfico 5 representa a média dos valores de ângulo de contato do grupo Gluconato de clorexidina $4 \%$, nos diferentes ciclos prévio e posterior à formação de película adquirida salivar.

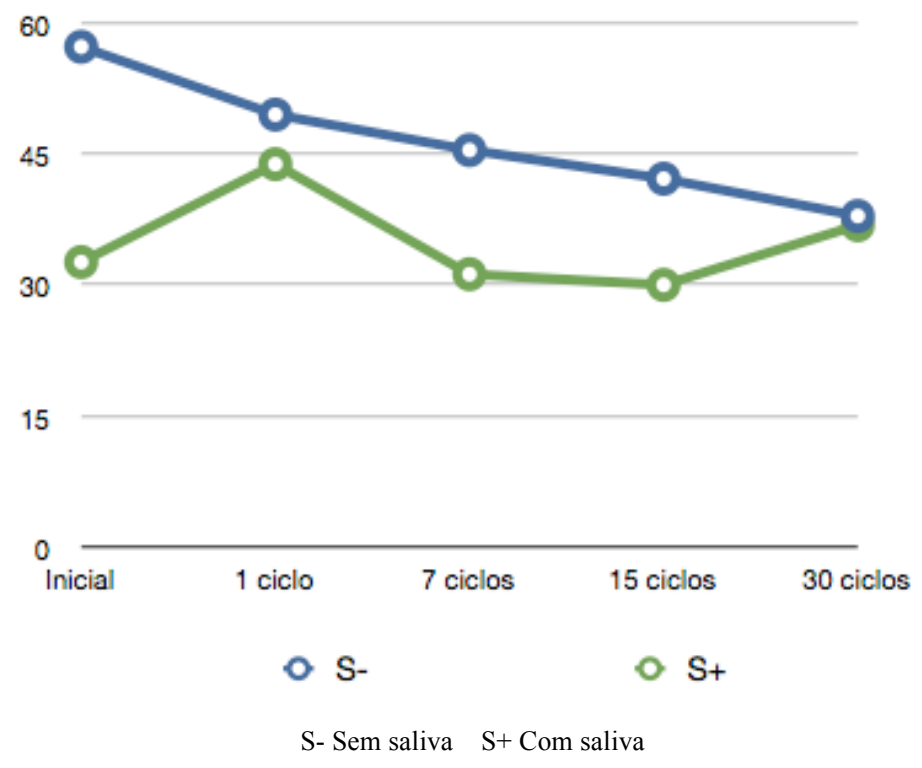


4.2 Experimento II: Colonização de $C$. albicans sobre resina acrílica termopolimerizável após desinfecção em soluções químicas.

\subsubsection{Grupo Controle}

$\mathrm{Na}$ análise da adesão de C. albicans sobre resina acrílica termopolimerizável, no grupo controle imerso em água destilada foram observados valores de média e desvio padrão respectivamente entre $99.53 \pm 29.84$ e $30.22 \pm 14.40$, prévio a formação da película adquirida salivar, sem que esses valores apresentassem diferença estatisticamente significante entre os diferentes períodos avaliados. (TABELA e GRÁFICO 6)

Após a formação da película adquirida salivar, foram observados valores entre $73.64 \pm 30.10$ e $10.28 \pm 3.53$, apresentando-se diferença estatisticamente significante exclusivamente entre os valores inicial e 30 ciclos. (TABELA e GRÁFICO 7)

Comparando os grupos com e sem saliva do grupo controle nos diferentes períodos avaliados, foi possível observar diferença estatisticamente significante unicamente nos períodos 1, 15 e 30 ciclos. (TABELA e GRÁFICO 8). Ilustrações (FIGURA 22) 


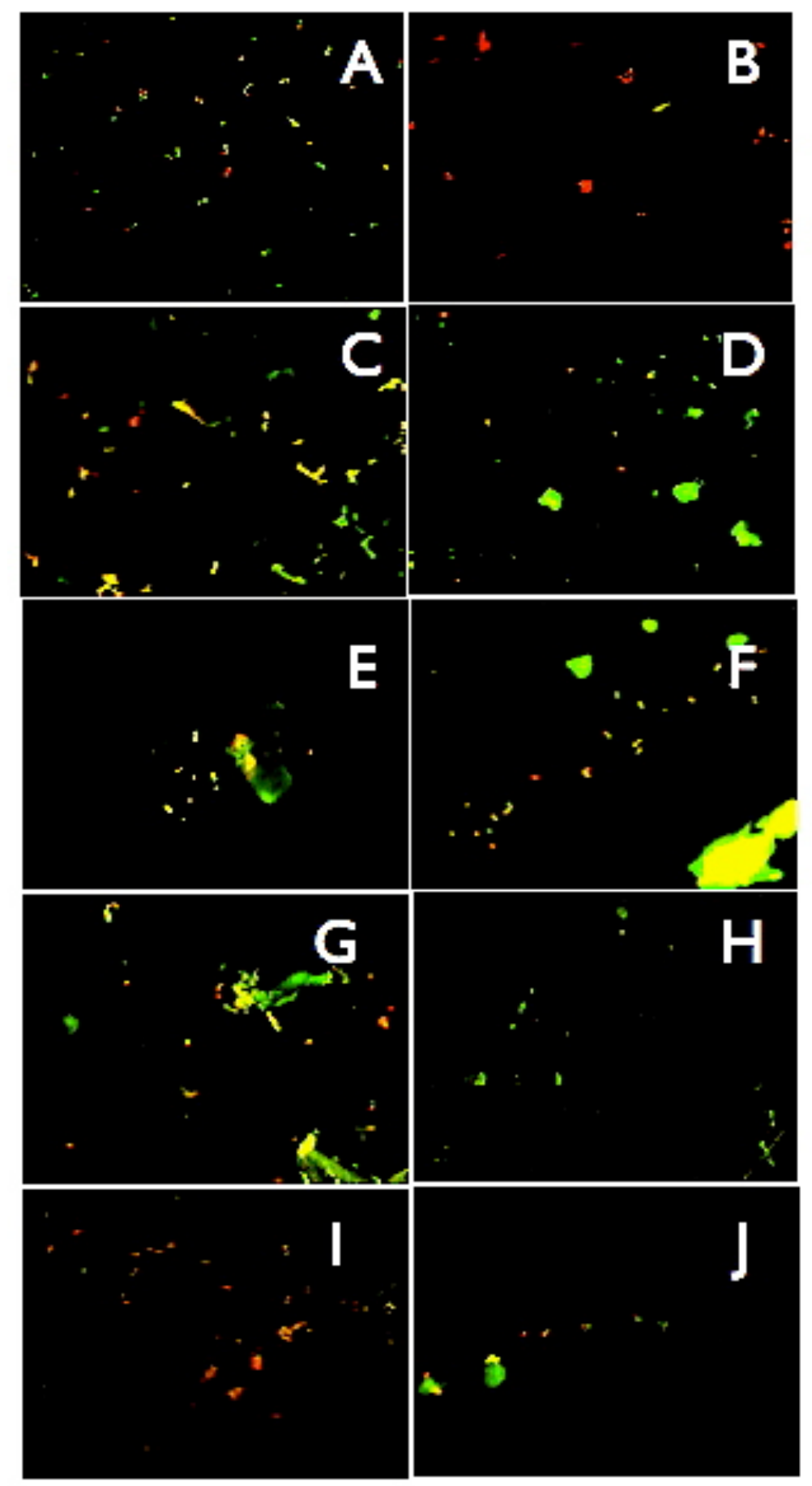

Figura 22: A-B: Imagem de campo obtida por microscopia do grupo controle inicial pré e pós película adquirida. C-D: Imagem de 1 ciclo pré e pós película adquirida. E-F Imagem de 7 ciclos pré e pós película adquirida. G-H: Imagem de 15 ciclos pré e pós película adquirida. I-J: Imagem 30 ciclos pré e pós película adquirida. 
A Tabela 6 representa a média e o desvio-padrão dos valores de células aderidas de $C$. albicans em cada grupo nos diferentes ciclos prévio à formação de película adquirida salivar

\begin{tabular}{c|c|c|c}
\hline Ciclos de desinfecção & Controle & \multicolumn{2}{|c}{ Soluções desinfetantes } \\
\hline & Agua Destilada & Hipoclorito de Sódio 1\% & Gluconato de Clorexidina 4\% \\
\hline Inicial & $99.53 \pm 29.84 a \mathrm{~A}$ & $99.53 \pm 29.84 \mathrm{aA}$ & $99.53 \pm 29.84 \mathrm{aA}$ \\
\hline 1 ciclo & $47.42 \pm 21.68 \mathrm{AA}$ & $96.81 \pm 46.70 \mathrm{abA}$ & $61.67 \pm 38.03 \mathrm{abA}$ \\
\hline 7 ciclos & $38.22 \pm 38.59 \mathrm{AA}$ & $37.06 \pm 30.24 \mathrm{abA}$ & $44.58 \pm 33.67 \mathrm{abcA}$ \\
\hline 15 ciclos & $30.81 \pm 15.70 a \mathrm{~A}$ & $37.25 \pm 12.96 \mathrm{abA}$ & $18.53 \pm 13.00 \mathrm{bcA}$ \\
\hline 30 ciclos & $30.22 \pm 14.40 a \mathrm{~A}$ & $19.03 \pm 10.37 \mathrm{bA}$ & $20.44 \pm 13.24 \mathrm{bA}$ \\
\hline
\end{tabular}

Tempos com a mesma letra minúscula em cada coluna e soluções com a mesma letra maiúscula em cada fila, não possuem diferença estatística significante entre si.

O Gráfico 6 representa a média dos valores de células aderidas de C. albicans de cada grupo nos diferentes ciclos avaliados, prévio à formação de película adquirida salivar

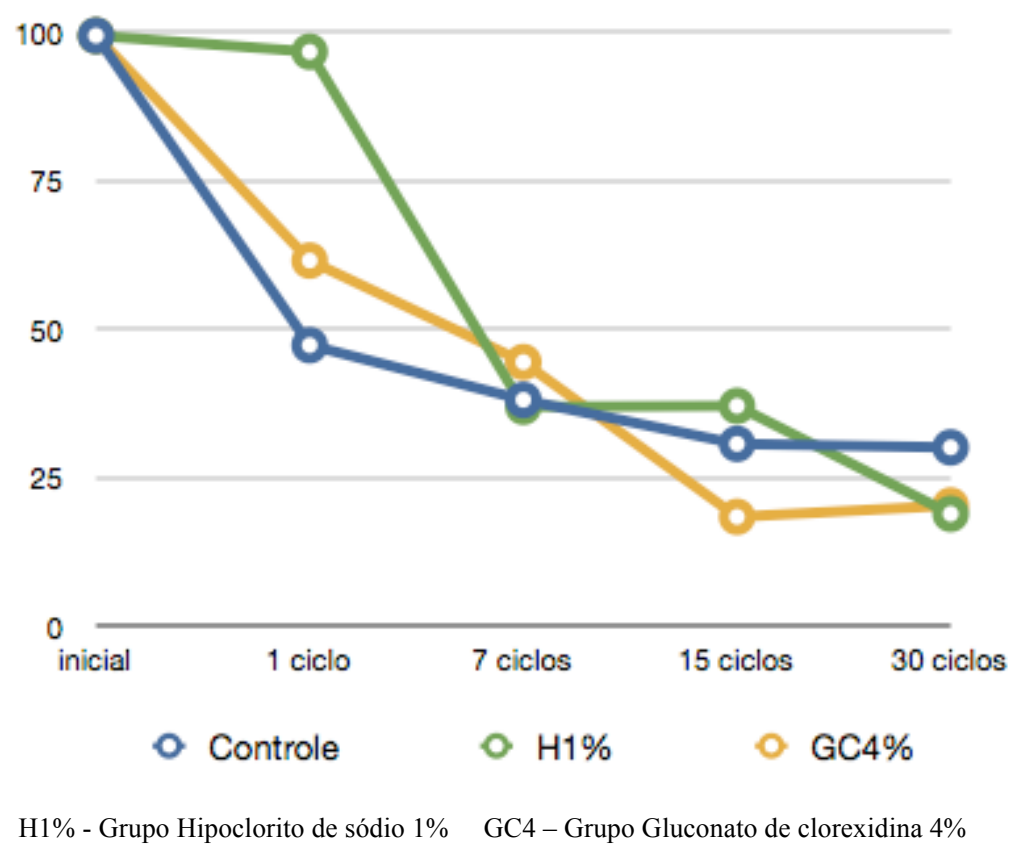




\subsubsection{Grupo Hipoclorito de sódio $1 \%$}

$\mathrm{Na}$ analise da adesão de C. albicans sobre resina acrílica termopolimerizável, no grupo experimental imerso em Hipoclorito de sódio 1\%, foram observados valores de media e desvio padrão entre $99.53 \pm 29.84$ e $19.03 \pm 10.37$, prévio a formação da película adquirida salivar. Observando-se diferença estatisticamente significante exclusivamente entre os períodos inicial e 30 ciclos. (TABELA e GRÁFICO 6)

Após a formação da película adquirida salivar, foram observados valores entre $73.64 \pm 30.10$ e $8.5 \pm 8.26$, apresentando-se diferença estatisticamente significante exclusivamente entre os valores inicial e 30 ciclos. (TABELA e GRÁFICO 7)

Comparando os grupos com e sem saliva do grupo experimental Hipoclorito de sódio $1 \%$ nos diferentes períodos avaliados, foi possível observar diferença estatisticamente significante unicamente nos períodos 1,15 e 30 ciclos. (TABELA 8) (GRÁFICO 9) Ilustrações (FIGURA 23). 


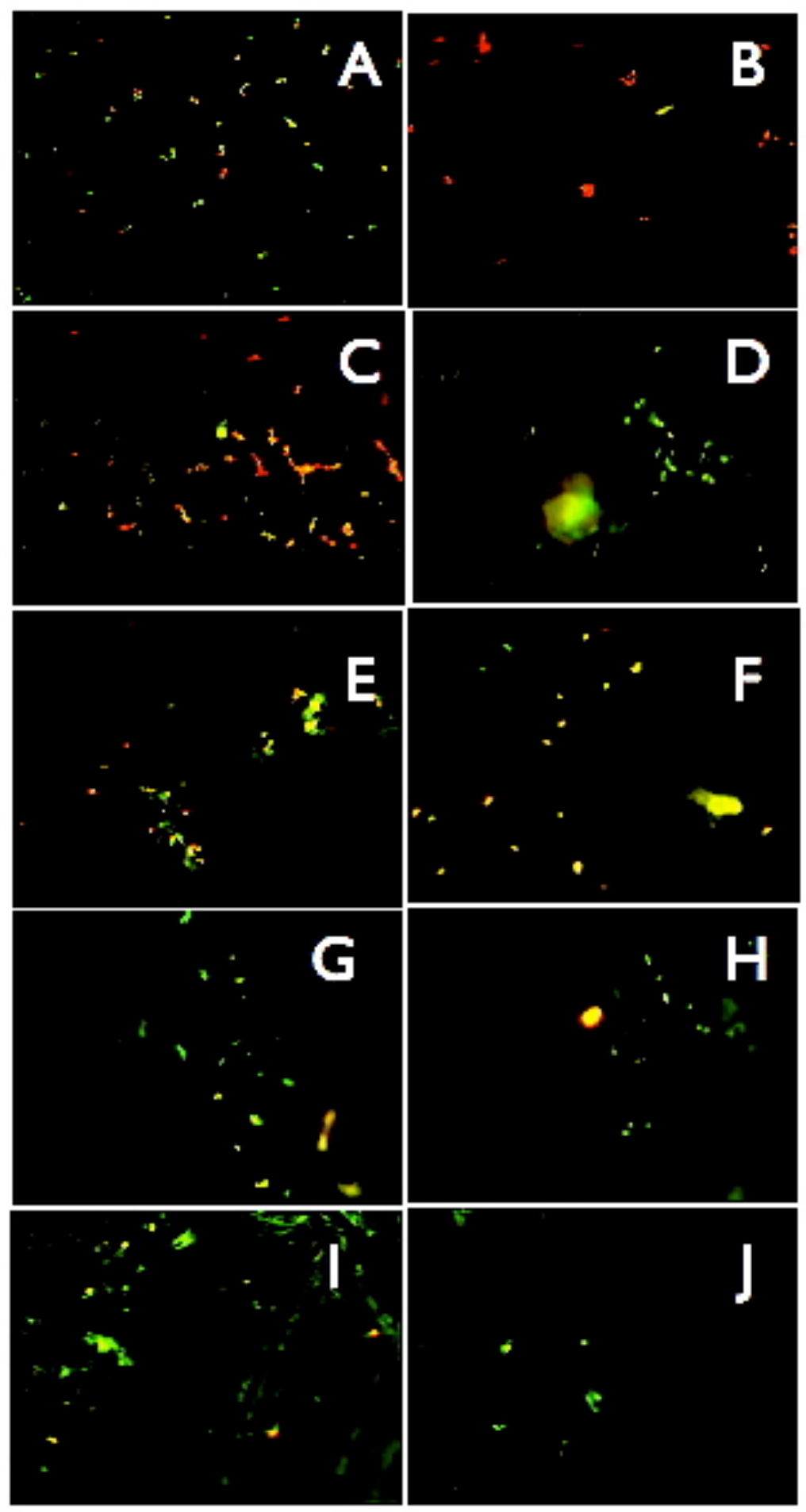

Figura 23: A-B: Imagem de campo obtida por microscopia do grupo Hipoclorito de sódio 1\%, inicial pré e pós película adquirida. . CD: Imagem de 1 ciclo pré e pós película adquirida. E-F Imagem de 7 ciclos pré e pós película adquirida. G-H: Imagem de 15 ciclos pré e pós película adquirida. I-J: Imagem 30 ciclos pré e pós película adquirida. 
A Tabela 7 representa a média e o desvio-padrão dos valores de células aderidas de $C$. albicans em cada grupo nos diferentes ciclos posterior à formação de película adquirida salivar.

\begin{tabular}{c|c|c|c}
\hline Ciclos de desinfecção & \multicolumn{1}{|c}{ Controle } & \multicolumn{2}{|c}{ Soluções desinfetantes } \\
\hline & Água Destilada & Hipoclorito de Sódio 1\% & Gluconato de Clorexidina 4\% \\
\hline Inicial & $73.64 \pm 30.10 a A$ & $73.64 \pm 30.10 a A$ & $73.64 \pm 30.10 a A$ \\
\hline 1 ciclo & $25.00 \pm 18.51 a b A$ & $38.22 \pm 23.26 a b A$ & $30.08 \pm 39.91 a A$ \\
\hline 7 ciclos & $23.70 \pm 13.93 a b A$ & $25.58 \pm 15.14 a b A$ & $57.97 \pm 29.66 a A$ \\
\hline 15 ciclos & $18.86 \pm 17.00 a b A$ & $39.92 \pm 22.82 a b A$ & $33.95 \pm 49.65 a A$ \\
\hline 30 ciclos & $10.28 \pm 3.53 b A$ & $8.5 \pm 8.26 b A$ & $16.11 \pm 8.42 a A$ \\
\hline
\end{tabular}

Tempos com a mesma letra minúscula em cada coluna e soluções com a mesma letra maiúscula em cada fila, não possuem diferença estatística significante entre si.

O Gráfico 7 representa a média dos valores de células aderidas de C. albicans de cada grupo nos diferentes ciclos avaliados, posterior à formação de película adquirida salivar.

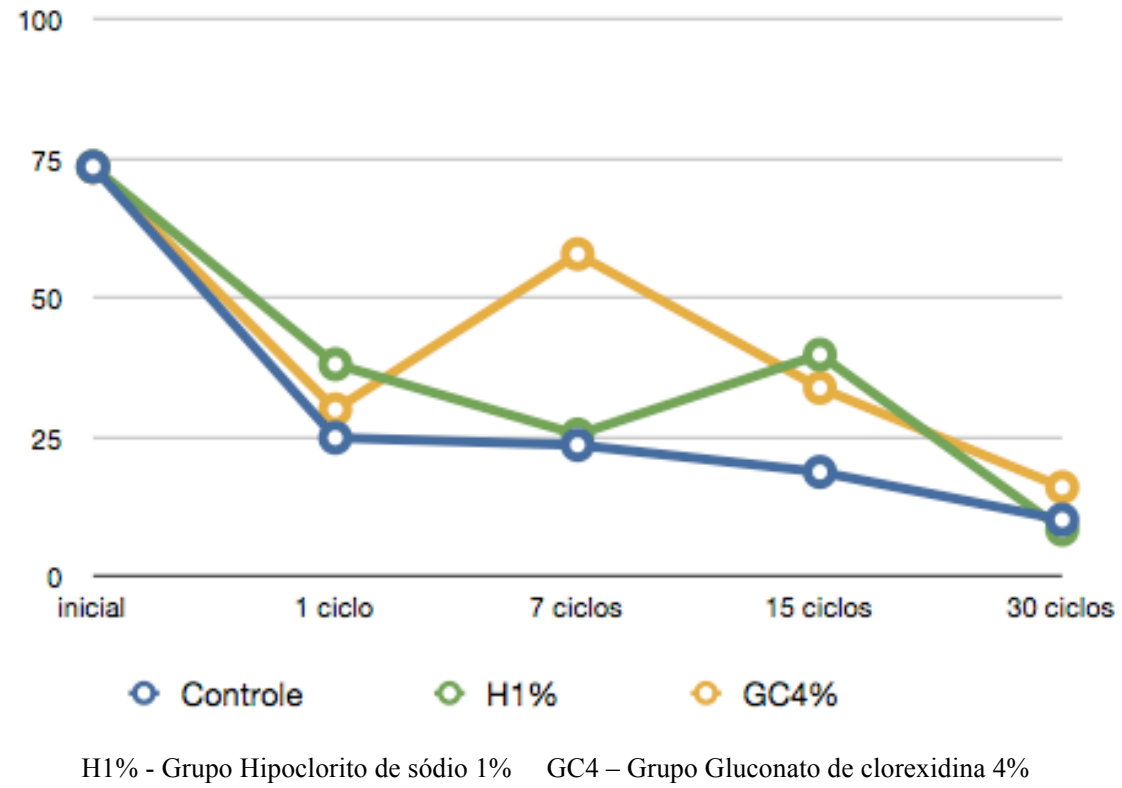




\subsubsection{Grupo Gluconato de clorexidina 4\%}

Na análise da adesão de C. albicans sobre resina acrílica termopolimerizável, no grupo experimental imerso em Gluconato de clorexidina 4\%, foram observados valores de média e desvio padrão respectivamente entre $99.53 \pm 29.84$ e $20.44 \pm 13.24$, prévio a formação da película adquirida salivar. Observando-se diferença estatisticamente significante quando comparado o período inicial vs. ciclos 15 e 30. (TABELA e GRÁFICO 6)

Após a formação da película adquirida salivar, foram observados valores entre $73.64 \pm 30.10$ e $16.11 \pm 8.42$, não apresentando-se diferença estatisticamente significante entre os valores correspondentes a os períodos avaliados. (TABELA e GRÁFICO 7)

Comparando os grupos com e sem saliva do grupo experimental Gluconato de clorexidina $4 \%$ nos diferentes períodos avaliados, foi possível observar diferença

estatisticamente significante exclusivamente no período 1 ciclo. (TABELA 8 e GRÁFICO 10). Ilustrações (FIGURA 24) 


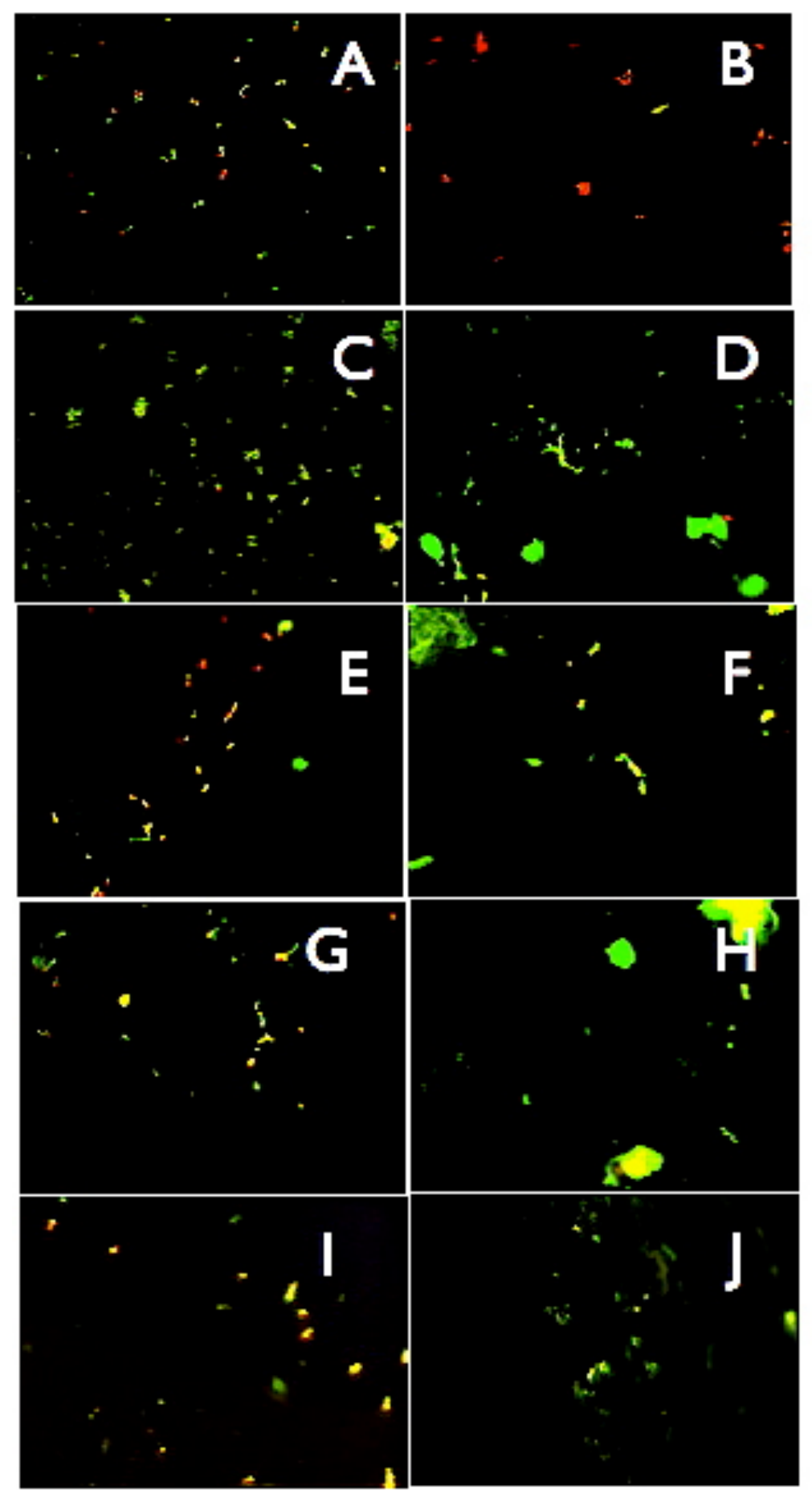

Figura 24: A-B: Imagem de campo obtida por microscopia do grupo Gluconato de clorexidina 4\%, inicial pré e pós película adquirida. C-D: Imagem de 1 ciclo pré e pós película adquirida. E-F Imagem de 7 ciclos pré e pós película adquirida. G-H: Imagem de 15 ciclos pré e pós película adquirida. I-J: Imagem 30 ciclos pré e pós película adquirida. 


\subsubsection{Comparação dos desinfetantes prévio à formação de película adquirida salivar}

Comparando os valores de adesão de $C$. albicans obtidos dos grupos controle e experimentais, previamente à formação de película adquirida salivar, não houve uma diferença estatística significante entre os grupos, nos diferentes períodos avaliados . (TABELA e GRÁFICO 6)

\subsubsection{Comparação dos desinfetantes posterior à formação de película adquirida salivar}

Comparando os valores de adesão de C. albicans obtidos dos grupos controle e experimentais, posterior à formação de película adquirida salivar, não houve uma diferença estatística significante entre os grupos, nos diferentes períodos avaliados . (TABELA e GRÁFICO 7)

A Tabela 8 representa a média e o desvio-padrão dos valores de células aderidas de $C$. albicans em cada grupo, nos diferentes ciclos prévio e posterior à formação de película adquirida salivar.

\begin{tabular}{|c|c|c|c|}
\hline Desinfetante & Ciclos & S- & $S+$ \\
\hline & Inicial & $99.53 \pm 29.84$ & $73.64 \pm 30.10$ \\
\hline & 1 ciclo & $47.42 \pm 21.68^{*}$ & $25.00 \pm 18.51^{*}$ \\
\hline \multirow[t]{5}{*}{ Controle } & 7 ciclos & $38.22 \pm 38.59$ & $23.70 \pm 13.93$ \\
\hline & 15 ciclos & $30.81 \pm 15.70^{*}$ & $18.86 \pm 17.00^{*}$ \\
\hline & 30 ciclos & $30.22 \pm 14.40^{*}$ & $10.28 \pm 3 \cdot 53^{*}$ \\
\hline & Inicial & $99.53 \pm 29.84$ & $73.64 \pm 30.10$ \\
\hline & 1 ciclos & $96.81 \pm 46.70^{*}$ & $38.22 \pm 23.26^{*}$ \\
\hline \multirow[t]{5}{*}{ Hipoclorito de Sódio 1\% } & 7 ciclos & $37.06 \pm 30.24$ & $25.58 \pm 15.14$ \\
\hline & 15 eiclos & $37.25 \pm 12.96^{*}$ & $39.92 \pm 22.82^{*}$ \\
\hline & 30 ciclos & $19.03 \pm 10.37^{*}$ & $8.5 \pm 8.26^{*}$ \\
\hline & Inicial & $99.53 \pm 29.84$ & $73.64 \pm 30.10$ \\
\hline & 1 ciclo & $61.67 \pm 38.03^{*}$ & $30.08 \pm 39.91^{*}$ \\
\hline \multirow[t]{3}{*}{ Gluconato de Clorexidina 4\% } & 7 ciclos & $44.58 \pm 33.67$ & $57.97 \pm 29.66$ \\
\hline & 15 ciclos & $18.53 \pm 13.00$ & $33.95 \pm 49.65$ \\
\hline & 30 ciclos & $20.44 \pm 13.24$ & $16.11 \pm 8.42$ \\
\hline
\end{tabular}

Valores com asterisco $(*)$ em cada solução e tempo testado possuem diferença estatisticamente significante. 
O Gráfico 8 representa a média dos valores dos valores de células aderidas de $C$. albicans do grupo controle nos diferentes ciclos avaliados, prévio e posterior formação de película adquirida salivar

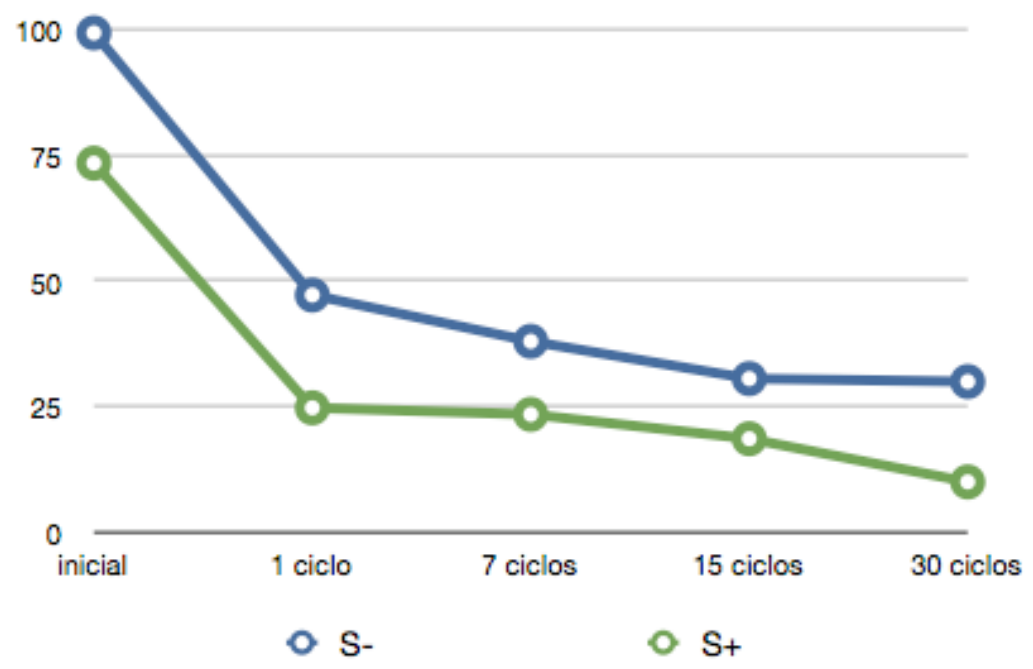

S- Sem saliva $\mathrm{S}+$ Com saliva

O Gráfico 9 representa a média dos valores dos valores de células aderidas de $C$. albicans do grupo Hipoclorito de sódio 1\%, nos diferentes ciclos avaliados, prévio e posterior formação de película adquirida salivar

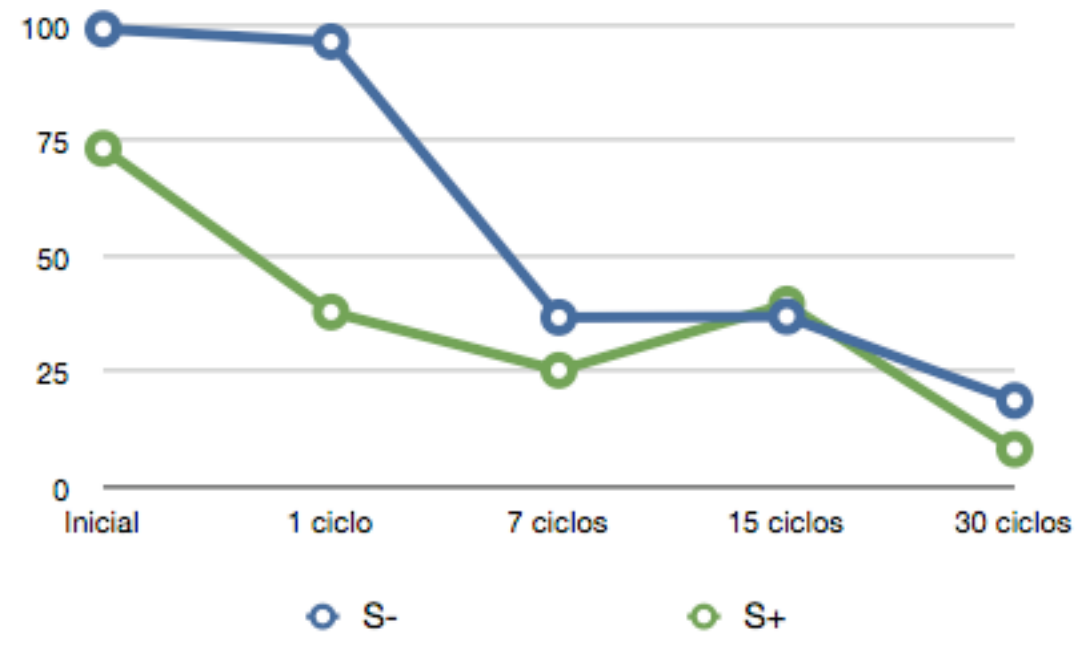

S- Sem saliva $\quad$ S+ Com saliva 
O Gráfico 10 representa a média dos valores dos valores de células aderidas de $C$. albicans do grupo Gluconato de clorexidina 4\%, nos diferentes ciclos avaliados, prévio e posterior formação de película adquirida salivar

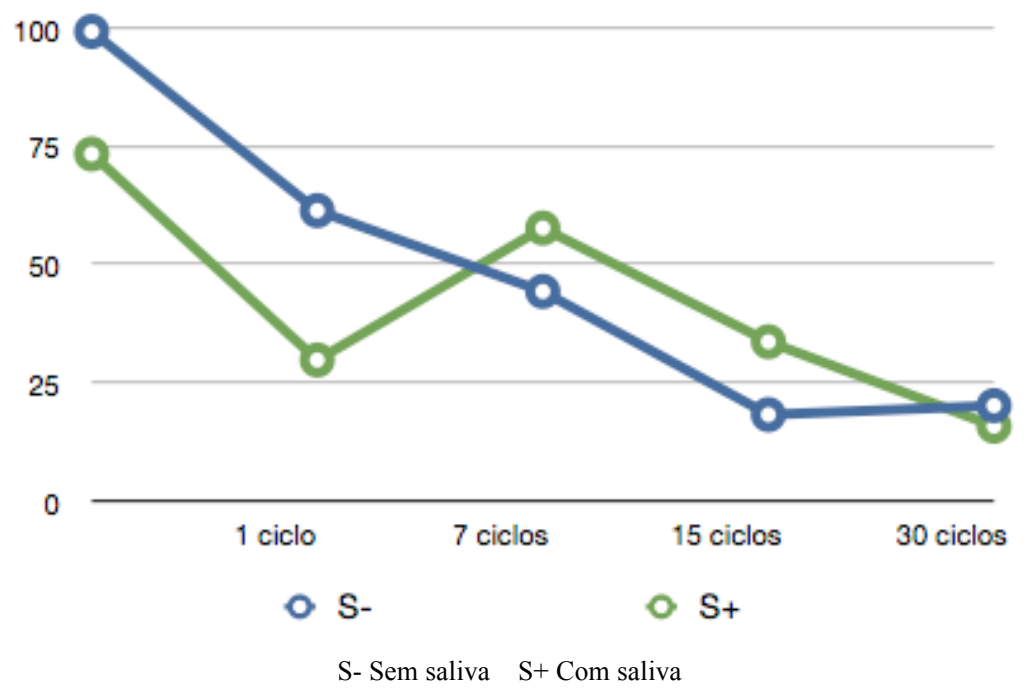




\subsection{Correlação entre hidrofobicidade superficial e adesão de $C$. albicans a resina} acrílica termopolimerizável pré e pós formação de película adquirida salivar

Após análise estatística, não foi possível afirmar que existe correlação entre o nível de adesão de $C$. albicans a resina acrílica termopolimerizável e hidrofobicidade superficial nos grupos avaliados, exceto para o grupo Controle e Gluconato de clorexidina 4\% antes da formação da película adquirida salivar. (TABELA 9)

A Tabela 9 representa o Valor de $\mathrm{P}$ do teste de correlação entre as variáveis Hidrofobicidade superficial e adesão de C. albicans à resina acrílica termopolimerizável prévio e posterior a formação de película adquirida salivar.

\begin{tabular}{c|c|c}
\hline Correlação & \multicolumn{2}{|c}{ Hidrofobicidade $\boldsymbol{x}$ Adesão } \\
\hline & $S-$ & $S+$ \\
\hline Controle & $0.0477^{*}$ & 0.3457 \\
\hline $\begin{array}{c}\text { Hipoclorito de } \\
\text { sódio 1\% }\end{array}$ & 0.8325 & 0.0676 \\
\hline $\begin{array}{c}\text { Gluconato de } \\
\text { Clorexidina 4\% }\end{array}$ & $0.006^{*}$ & 0.5055 \\
\hline
\end{tabular}

Valores com asterisco (*) em cada solução possuem diferença estatisticamente significante. 


\section{DISCUSSÃO}

\subsection{Discussão de materiais e método}

A adesão de microorganismos a materiais de confecção de próteses compreende um complexo sistema que ainda hoje não está bem elucidado (TEUGHELS et al., 2006). A adesão da $C$. albicans a materiais poliméricos, em especial a resina acrílica para confecção de dentaduras, não foge dessa afirmação, pois inúmeros fatores "in vivo" interferem na adesão do fungo na cavidade oral. Fatores como a deglutição, movimentos musculares e a presença de saliva interagem amortecendo ou permitindo maior ou menor adesão microbiana a superfícies orais. (TEUGHELS et al., 2006)

Características superficiais dos materiais e da C. albicans já têm sido associados à adesão. A rugosidade superficial e a hidrofobicidade, entre outros, têm sido relatados na literatura como variáveis importantes ao se estudar a capacidade de adesão do fungo.

No que se refere a Hidrofobicidade, a literatura é confusa na terminologia correta para designar a interação dos líquidos com superfícies sólidas. Termos como Energia livre de superfície e molhabilidade também são utilizados e às vezes confundidos. A Energia livre de superfície é definida como a interação entre as forças de coesão e as forças de adesão, que determinariam a ocorrência ou não de molhabilidade em um sólido. Para a mensuração exata da energia livre de superfície é preciso utilizar vários líquidos de diferentes tensões superficiais que, após o contato com a superfície sólida, formam um ângulo de contato. A análise e comparação deste ângulo pode dar informações das características físico-químicas do substrato. Já a molhabilidade é considerada como a qualidade ou estado de um sólido ser umidificável, ou o grau a que pode ser umidecido; também pode ser definida como a capacidade de qualquer superfície sólida de ficar molhada quando em contato com um líquido cuja tensão superficial foi reduzida, de modo que o líquido se espalha sobre a superfície do sólido. O termo adotado neste trabalho foi o de Hidrofobicidade superficial por ser considerado o mais apropriado para a técnica desenvolvida para a obtenção de resultados. A hidrofobicidade superficial indica o grau de repulsão à água que um sólido possui, podendo informar as características físico-químicas do substrato testado. 
Para a mensuração da hidrofobicidade superficial foi utilizada água milli-Q, por considerar que o teste é altamente sensível a contaminação e componentes iônicos do líquido utilizado. A temperatura do líquido (Temperatura ambiente) também foi considerada, já que um aumento na temperatura do líquido utilizado produziria ângulos de contato menores ao diminuir sua tensão superficial, enquanto que um aumento na temperatura produziria o efeito contrário (DE JONG; VAN PELT; ARENDS, 1982). A rugosidade do espécime é um fator importante a considerar, já que mudanças de mais de $0.1 \mu \mathrm{m}$ no substrato produzem variações na mensuração do ângulo de contato, dependente do valor do ângulo de contato na superfície lisa (Valor inicial). Assim, superfícies que apresentarem valores iniciais de ângulo de contato menor a $60^{\circ} \mathrm{em}$ caso de aumento da rugosidade apresentariam valores finais menores de ângulo de contato, enquanto que se o ângulo de contato inicial é maior a $86^{\circ}$ a rugosidade aumentaria esse ângulo final. Em ângulos iniciais entre $60^{\circ}$ e $86^{\circ}$ a rugosidade não teria influência no ângulo de contato final. (BUSSCHER et al., 1984; DE JONG; VAN PELT; ARENDS, 1982; NAKAE; HIRATA; HIROYUKE, 1998). Por esse motivo, e para possibilitar a posterior comparação com os resultados de adesão de C. albicans, foi considerada uma rugosidade de aproximadamente $2 \mu \mathrm{m}$ que está acima do limiar de adesão microbiana de $0.2 \mu \mathrm{m}$ (QUIRYNEN; BOLLEN, 1995; TEUGHELS et al., 2006) e não influenciaria na mensuração da hidrofobicidade superficial, devido a que os valores de rugosidade superficial da resina Lucitone não são modificados significantemente após 30 ciclos de desinfecção utilizando Hipoclorito de sódio $1 \%$ ou Gluconato de clorexidina 4\%. (PINTO, 2007).

O mecanismo de registro por meio de fotografias do ângulo de contato é um método eficaz e simples viabilizando a realização do teste e já utilizada com sucesso (DE JONG; VAN PELT; ARENDS, 1982; DE JONG et al., 1984; NAKAE; HIRATA; HIROYUKE, 1998; YILDIRIM et al., 2005). A padronização de distância entre substrato e máquina fotográfica, e parâmetros fotográficos como abertura e velocidade são considerados importantes e devem ser observados.

A formação da película adquirida salivar na cavidade oral é documentada como uma variável capaz de interferir na capacidade de adesão da C. albicans. Resultados discordantes são reportados na literatura e diversas são as conclusões a respeito ao 
verdadeiro papel da saliva na adesão de C. albicans. Enquanto alguns autores concluem que a saliva humana aumenta a adesão de C. albicans a superfícies acrílicas, (MILLSAP et al., 1999; SAMARANAYAKE; NAIR, 1995; VASILAS et al., 1992) devido a componentes como a mucina, (DODDS; JOHNSON; YEH, 2005; EDGERTON et al., 1993; NIKAWA; HAMADA, 1990; NIKAWA et al., 1993) estaterina (JOHANSSON et al., 2000) (que facilitam a adesão da $C$. albicans a materiais resilientes embebidos em saliva) (NIKAWA et al., 2000) outros afirmam que a saliva diminui a adesão, (BOSCH et al., 2003; MAZA et al., 2002; MILLSAP et al., 1999; MOURA et al., 2006; NIKAWA et al., 1992b; PEREIRA-CENCI et al., 2007; SAMARANAYAKE; MACFARLANE, 1980; WATERS et al., 1997) devido a componentes como lisozima, histanina, lactoferrina, calprotectina e S-IgA que interagem com as espécies de Candida diminuindo sua adesão. (CANNON; CHAFFIN, 2001; DODDS; JOHNSON; YEH, 2005; ELGUEZABAL; MAZA; PONTON, 2004; TANIDA et al., 2001) Ainda, alguns autores relataram que não há influência alguma da saliva na adesão da $C$. albicans aos materiais acrílicos (JIN et al., 2004; NIKAWA et al., 1992a; TARI et al., 2007), isso devido a numerosos protocolos de obtenção e natureza da saliva coletada. Neste trabalho foi utilizada saliva humana não estimulada, com o intuito de verificar o efeito da formação da película adquirida salivar tanto na hidrofobicidade superficial, como na adesão da $C$. albicans sobre resina acrílica termopolimerizável.

Saliva humana não estimulada foi utilizada, pois apresenta $70 \%$ de saliva proveniente das glândulas submandibular/sublingual, 15-20\% da glândula parótida e 5$8 \%$ das glândulas salivares menores, consideradas as responsáveis pela maior parte da formação da película adquirida salivar na superfície interna da prótese total. Na saliva estimulada, $45-50 \%$ provém da parótida e quantidades menores das glândulas salivares menores (SREEBNY, 2000). Idealmente, a saliva proveniente das glândulas salivares menores do palato deveria ser utilizada para a formação da película adquirida salivar, mas poucos trabalhos têm sido desenvolvidos referentes a este assunto (EDGERTON et al., 1993) devido a falta de conhecimento da natureza da secreção e dificuldade de coleta. A maioria destes trabalhos se restringe ao uso de saliva proveniente das glândulas salivares menores labiais devido a facilidade de obtenção, apesar das pequenas quantidades (RADFORD; CHALLACOMBE; WALTER, 1999). 
É reconhecido na literatura que a adesão de Candida sp. compreende um processo complexo, pela grande quantidade de fatores que são envolvidos, o que poderia justificar as contradições que são reportadas entre os resultados de trabalhos realizados in vitro.

Um método de estudo para analisar a adesão microbiana a polímeros plásticos, em especial de C. albicans ao acrílico para dentadura, não está padronizado, assim não existe um protocolo experimental único. O sistema mais utilizado é a contagem de campos por meio microscópico (MCCOURTIE; DOUGLAS, 1981; MINAGI et al., 1985; MOURA et al., 2006; NAIR; SAMARANAYAKE, 1994; PARK et al., 2008; RADFORD et al., 1998; SAMARANAYAKE; MACFARLANE， 1980; WALTIMO; VALLITTU; HAAPASALO, 2001; YILDIRIM et al., 2005), outros métodos utilizados são: marcação dos microorganismos com elementos radioativos como a metionina o uridina (VASILAS et al., 1992; WEBB et al., 1995), microscópico eletrônico (NIKAWA et al., 1993; OKITA et al., 1991; WALTIMO et al., 1999), capacidade de crescimento de UFC (unidades formadoras de colônias) após diluições seriadas (BURNS et al., 1987; PARANHOS et al., 2009; RIBEIRO et al., 2009; SPIECHOWICZ et al., 1990). Cada autor utiliza a metodologia dependendo de disponibilidade, viabilidade e domínio da técnica selecionada. (SERRANO-GRANGER et al., 2005)

Diversas espécies de Candida $s p$ são utilizadas para ensaios de adesão e desinfecção na literatura (MOURA et al., 2006; SANITA et al., 2009) (MINAGI et al., 1985; SERRANO-GRANGER et al., 2005), o que dificulta a completa comparação de resultados. Neste estudo foi utilizada a cepa de Candida ATCC 90028, utilizada em vários experimentos na literatura (CAMACHO; GASPARETTO; SVIDZINSKI, 2007; MUTAI et al., 2009; SANITA et al., 2009). Assim como o método selecionado para contagem celular, a eleição da cepa na maioria das vezes é eleição do pesquisador, pois não há padronização, exceto em casos pontuais, onde um determinado tipo de cepa apresente características concretas para desenvolver um projeto especfico.

Observa-se na literatura uma grande variação na concentração do inóculo microbiano empregado em estudos similares, variando desde $10^{5}$ (NIKAWA et al., 1993) a $10^{8}$ (SEGAL; LEHRMAN; DAYAN, 1988; WALTIMO et al., 1999), o que pode explicar divergências entre alguns resultados encontrados, pois uma concentração microbiana elevada pode favorecer uma contaminação mais intensa e extensa da 
superfície da resina acrílica. Neste estudo foi selecionada a concentração de $10^{7}$ por ser a mais amplamente utilizada (CHANDRA et al., 2001; MINAGI et al., 1985; NIKAWA; HAMADA, 1990; NIKAWA et al., 1992a; RADFORD et al., 1998; SAMARANAYAKE; MACFARLANE, 1980; VERRAN; MOTTERAM, 1987; WATERS et al., 1997).

A temperatura e tempo de incubação para a fase de adesão selecionado foi de 90 minutos a $37^{\circ} \mathrm{C}$ preconizada por Chandra et al (CHANDRA et al., 2001). A temperatura de $37^{\circ} \mathrm{C}$ foi selecionada por reproduzir "in vitro" a temperatura média da cavidade oral. Em relação ao tempo de incubação, a literatura relata desde uma hora (MINAGI et al., 1985; SAMARANAYAKE; MACFARLANE, 1980; TSANG; HONG, 2009; VERRAN; MOTTERAM, 1987; WATERS et al., 1997) a duas horas (NIKAWA et al., 1993; OKITA et al., 1991; VASILAS et al., 1992; WEBB et al., 1995). Segundo Maza et al 2002 (MAZA et al., 2002) o máximo de adesão é atingida em 2 horas. Uma hora e trinta minutos é considerado por Chandra et al 2001 (CHANDRA et al., 2001) como o tempo de adesão ideal para formação de biofilme de C. albicans.

A eleição do método de coloração para posterior análise por microscopia é uma das variáveis nos trabalhos publicados na literatura. Diversos corantes são utilizados como violeta cristal (MCCOURTIE; DOUGLAS, 1981; MINAGI et al., 1985; OKITA et al., 1991; SILVA et al., 2009), Coloração Gram (NAIR; SAMARANAYAKE, 1994; SAMARANAYAKE; MACFARLANE, 1980) e branco calcofluor 0.1\% (MAZA et al., 2002) e a $1 \%$ (SENTANDREU et al., 1997). Neste estudo optou-se por fluorocromo de Laranja de acridina devido à disponibilidade, conhecimento da técnica e uso na literatura. (GRANGER, 2002; SARDIN et al., 2004; SERRANO-GRANGER et al., 2005).

Embora para a correlação direta entre o Experimento I (Hidrofobicidade Superficial) e II (adesão de C. albicans) seria ideal o uso do mesmo espécime, as condições requeridas para o uso de microscopia e fluorocromo para contagem de células aderidas no acrílico termopolimerizável para base de dentadura inviabilizaram esta condição. O uso de acrílico termopolimerizável cor rosa médio e incolor nos Experimentos I e II não impede a correlação dos resultados, pois variações de composição como colorantes, agentes de entrecruzamento e estabilizantes que melhorem 
as propriedades da resina, não se traduzem em grandes diferenças nos valores de hidrofobicidade superficial do material. (GRANGER, 2002).

Para este estudo foram utilizados 6 espécimes em cada grupo testado, representando uma média do número de espécimes utilizados em alguns estudos similares reportados na literatura, onde foram utilizados: 10 espécimes (SERRANO-GRANGER et al., 2005), 6 espécimes (EDGERTON et al., 1993) e 4 espécimes (VASILAS et al., 1992)

\subsection{Discussão de resultados}

No presente trabalho, os dados obtidos de hidrofobicidade superficial após desinfecção química e formação de película adquirida salivar indicam que existem diferenças estatisticamente significativas, após a análise estatística utilizando o teste paramétrico para medidas repetidas (Repeated measures ANOVA) e T-pareado.

Nenhum trabalho na literatura relaciona mudanças na hidrofobicidade superficial da resina acrílica termopolimerizável após desinfecção química ou imersão em água.

Os resultados de ângulo de contato obtidos neste trabalho para resina termopolimerizável para dentadura apresentaram valores iniciais entre 57.33 e $59.06^{\circ}$. Os valores relatados na literatura variam de desde $78.65^{\circ}$ para a resina termopolimerizável Meliodent (Yildirim 2005), 68.64 ${ }^{\circ}$ para a resina termopolimerizável Lucitone (SERRANO-GRANGER et al., 2005) e entre 69-90 para 9 resinas termopolimerizáveis (MINAGI et al., 1985). Essa diferença entre valores reportados na literatura pode se dever às diferentes metodologias utilizadas, pelas quais é possível mensurar a hidrofobicidade superficial de um sólido, desde a técnica da gota séssil utilizada neste estudo e por outros autores (SARDIN et al., 2004; WEERKAMP; VAN DER MEI; BUSSCHER, 1985), técnica de força de molhabilidade, utilizando tensiômetro (SIPAHI; ANIL; BAYRAMLI, 2001) e ângulo de contato dinâmico (ZISSIS et al., 2001).

Comparado com os valores iniciais, uma diminuição estatisticamente significante foi observada a partir do primeiro ciclo de desinfecção nos valores de ângulo de contato nos grupos controle e Gluconato de clorexidina 4\%; no grupo Hipoclorito de sódio $1 \%$ essa diminuição foi observada a partir do sétimo ciclo de desinfecção. Assim é possível afirmar que a imersão em soluções aquosas modifica as características físico- 
químicas da resina acrílica. Oscilações nos valores através dos períodos avaliados foram observadas no grupo Hipoclorito sódio $1 \%$ e diminuição constante no grupo Gluconato de clorexidina $4 \%$. Frente à alta variabilidade dos resultados, pode-se afirmar que o Hipoclorito de sódio $1 \%$ foi o único desinfetante utilizado que se diferenciou dos grupos controle e Gluconato de clorexidina $4 \%$ em todos os períodos, exceto no valor inicial, onde todos os grupos apresentaram valores semelhantes, resultado esperado já que todos os espécimes apresentavam as mesmas condições nos ensaios iniciais. Essas mudanças na hidrofobicidade do Hipoclorito $1 \%$ pode ser embasada na possível absorção por parte da resina acrílica de Íons de hidróxido $(\mathrm{OH})$ presentes no Hipoclorito de sódio para aumentar seu potencial de limpeza e estabilizar compostos clorados livres em forma de OCl. Estes íons de hidróxido presentes na solução podem ser absorvidos por superfícies sólidas hidrofílicas, carregando-a negativamente (FUKUZAKI, 2006). Superfícies hidrofílicas podem se transformar em hidrofóbicas frente a duas realidades: quando o $\mathrm{pH}$ da solução onde o sólido está imerso se encontra no ponto isoelétrico (equilíbrio entre as cargas positivas e negativas) e quando são administrados íons plurivalentes na solução de imersão, cuja função é neutralizar total ou parcialmente o substrato (OSS, 1995).

Uma diminuição do ângulo de contato foi observada em todos os grupos após a formação da película adquirida salivar, fato relatado também na literatura por Minagi et al (MINAGI et al., 1985), onde valores de ângulo de contato diminuíram desde $78.65^{\circ}$ até $38.10^{\circ}$, e Sipahi et al (SIPAHI; ANIL; BAYRAMLI, 2001), onde os valores diminuíram desde 54.18 até 35.38. Esse achado corrobora a capacidade da película adquirida salivar de alterar as propriedades das superfícies as quais foi exposta. Quando comparados os resultados pré e pós película adquirida, foi possível observar diferença estatisticamente significante em alguns períodos dos grupos controle e Gluconato de clorexidina 4\%, enquanto que no grupo Hipoclorito de sódio $1 \%$ foi possível observar diferença estatística em todos os ciclos de desinfecção avaliados. Isso ocorreu provavelmente devido à alta variabilidade na deposição protéica proveniente da saliva. A formação da película adquirida salivaré um processo altamente dinâmico, que inclui forças eletrostáticas, forças de Van der Walls e hidrofóbicas, e dependente das características físico-químicas da superfície onde vai se formar (TEUGHELS et al., 2006). O processo está baseado primariamente na concentração da solução salivar, solubilidade e dependente da absorção 
protéica da superfície base, enquanto que uma absorção secundária está regulada pela composição química da superfície (EDGERTON et al., 1993; MILLEDING et al., 1999), o que dificulta a total reprodução in vitro da formação da película adquirida salivar, embora sejam seguidos rigorosos padrões de uniformidade na metodologia.

A participação de um único doador, a utilização da saliva não estimulada no mesmo dia do experimento, a padronização no método de clarificação da saliva e horário de coleta foram alguns dos parâmetros considerados para diminuir essas diferenças reportadas na literatura.

Os valores de ângulos de contato obtidos em todos os ciclos de desinfecção avaliados, tanto prévio como posterior a formação de película adquirida salivar, foram menores do limiar de $90^{\circ}$ para considerar uma superfície hidrofóbica; assim podemos afirmar que a resina acrílica termopolimerizável apresentou características de hidrofilicidade durante todo o experimento.

Existe um consenso na literatura em afirmar que a característica de hidrofilicidade está relacionada a boas condições de retentividade da prótese total e maior absorção de proteínas salivares (YILDIRIM et al., 2006), e as características hidrofóbicas relacionadas a uma maior estabilidade e absorção de cores do material (COMBE; OWEN; HODGES, 2004; SIPAHI; ANIL; BAYRAMLI, 2001; ZISSIS et al., 2001). Não existe na literatura um limiar de valor de ângulo de contato para que um material acrílico de confecção de bases de dentaduras possa ser considerado com melhores condições de retentividade da prótese total, mas Zissis et al (ZISSIS et al., 2001), relata que para uma prótese total exibir uma adesão adequada a os tecidos de suporte, a saliva deve fluir livremente sobre as superfícies. Essa capacidade da saliva se espalhar pela superfície do acrílico está relacionada a fatores como a viscosidade da saliva, rugosidade da superfície e homogeneidade na hidrofobicidade dos materiais. A estabilidade das próteses totais está relacionada a fatores físicos, mecânicos, químicos e biológicos; os fatores físicos relacionam-se a pressão atmosférica, forças de coesão e adesão.

Avaliando a adesão de C. albicans à resina acrílica termopolimerizável, após desinfecção química, podemos observar que previamente a formação de película adquirida salivar, uma diminuição na adesão de C. albicans ATTC 90028 foi observada em todos os grupos, sendo estatisticamente significante somente no período de 30 ciclos 
de desinfecção do grupo Hipoclorito de sódio $1 \%$ e nos períodos 15 e 30 ciclos do grupo Gluconato de clorexidina 4\%. Apesar de não haver diferença estatística entre os grupos através dos períodos avaliados, com certa cautela, é possível afirmar que o desinfetante Gluconato de clorexidina 4\% conseguiu uma diminuição na adesão de C. albicans ATTC 90028 num período menor ( 15 ciclos) frente ao Hipoclorito de sódio 1\% (30 ciclos).

Esse resultado poderia ser esperado devido a característica de substantividade do Gluconato de clorexidina na resina acrílica, produzindo uma diminuição na adesão de $C$. albicans, reportado em vários trabalhos "in vitro" (MCCOURTIE; MACFARLANE; SAMARANAYAKE, 1985; SPIECHOWICZ et al., 1990). Já trabalhos In Vivo, utilizando clorexidina gel 1\% como dentifrício, não mostrou diferenças estatisticamente significantes frente ao placebo (BUDTZ-JORGENSEN; MILTON KNUDSEN, 1978)

Para o Hipoclorito de sódio 1\%, alguns trabalhos afirmam que concentrações sub-inibitórias (1/50) do desinfetante são capazes de inibir a adesão a superfícies acrílicas. De acordo com o trabalho do Webb et al (WEBB et al., 1995), quando a espécie C. albicans é colocada em contato com concentrações sub-inibitórias de Hipoclorito de sódio (1/50) uma diminuição na adesão a superfícies acrílicas é observada, enquanto que em outras espécies Candida. um aumento ou nenhum efeito na adesão é observada, associando este efeito ao fato de que o mecanismo de adesão microbiana a superfícies inertes está associada a forças não específicas como a hidrofobicidade. No trabalho de Barnabé et al (BARNABE et al., 2004), uma melhora nas condições clínicas de quadros de estomatite foi observada em pacientes portadores de dentaduras, após a implementação de um protocolo de desinfecção utilizando Hipoclorito de sódio 1\%, embora essa melhora não fosse associada a uma diminuição significante na contagem de C. albicans, e sim a uma diminuição na contagem de Streptococos mutans, microorganismo associado ao aparecimento da patologia.

Os resultados deste estudo seguem os resultados reportados por Sharp et al (SHARP; VERRAN, 1985), no qual uma diminuição na formação de placa microbiana "in vivo" foi observada nas dentaduras após a utilização de dois agentes de limpeza de dentaduras (Peróxidos efervescentes). Os autores explicam este fenômeno baseados possivelmente em algum efeito inibitório do componente ativo do desinfetante permanece no acrílico, tendo uma ação nas células que inicialmente se aderem ao acrílico. Embora 
nosso estudo não tenha sido utilizado peróxidos efervescentes, podemos concordar que possivelmente algum componente ativo permaneceu na superfície acrílica, afetando a adesão de células de $C$. albicans.

A discrepância que se relata na literatura sobre o efeito dos desinfetantes na superfície de resinas acrílicas é comentada por Nikawa et al (NIKAWA et al., 1999), onde o autor relata que aparentemente quando comparados os achados "in vitro" a os achados clínicos, as soluções desinfetantes não parecem ser tão efetivas.

Uma alta variabilidade foi observada no número de células aderidas de um campo a outro nos espécimes ao ser analisados no microscópio de fluorescência, já que é possível afirmar que a adesão de C. albicans ao acrílico termopolimerizável não segue um padrão de normalidade. Era possível ver campos com poucas células aderidas, enquanto outros com alta quantidade de células formando um conglomerado, o que dificulta a posterior contagem celular, fato anteriormente relatado por Verran et al (VERRAN; MARYAN, 1997), Radford et al (RADFORD; CHALLACOMBE; WALTER, 1999) e Granger et al (GRANGER, 2002) Vasilas et al (VASILAS et al., 1992).

Quando observados os resultados de adesão de C. albicans ATTC 90028, após a formação da película adquirida salivar, foi possível observar que nenhuma diferença significante na contagem de células aderidas, comparando os grupos testados nos diferentes períodos avaliados. Observando os grupos isoladamente foi possível observar diferença estatística no período 30 ciclos em relação ao valor inicial em todos os grupos. Resultado que segue os achados do Miyake et al (MIYAKE et al., 1986), quem afirmou que a formação de película adquirida salivar diminui o ângulo de contato e consequentemente diminui a adesão de espécies de Candida hidrofóbicas, não afetando a adesão de espécies mais hidrofílicas como a C. albicans. Comparando os achados de adesão de C. albicans, pré e pós a formação da película adquirida salivar, observamos que embora fosse observada uma diminuição na adesão, somente em alguns dos períodos essa diminuição foi estatisticamente significante, o que confirma a variabilidade de resultados achados na literatura, dificultando o entendimento do verdadeiro papel da formação da película adquirida salivar na adesão de C. albicans à resina acrílica. 
Analisando as variáveis hidrofobicidade superficial e adesão de C. albicans ao acrílico termopolimerizável, não foi possível achar correlação positiva nos grupos testados pré e pós formação de película adquirida, exceto nos grupos controle e Gluconato de clorexidina 4\% prévio a formação da película adquirida salivar. Resultados parecidos foram observados por Moura et al (MOURA et al., 2006) Granger et al 2005 (SERRANO-GRANGER et al., 2005) e onde não foi possível correlacionar os valores de hidrofobicidade superficial com a adesão de C. albicans a superfícies de resina acrílica termopolimerizável. Enquanto que Minagi et al (MINAGI et al., 1985) afirma a existência de correlação entre a hidrofobicidade superficial e adesão de Candida sp. a superfícies acrílicas, devido a espécie hidrofílica $C$. albicans se aderir em maior proporção a superfícies acrílicas hidrofílicas em comparação a espécie mais hidrofóbica C. tropicalis. Estas discrepâncias achadas na literatura podem se embasar no fato de que os estudos que avaliaram a possível correlação entre hidrofobicidade superficial e adesão de C. albicans apresentaram diferenças na metodologia, assim os estudos mais recentes utilizaram uma metodologia mais moderna e exata na quantificação da hidrofobicidade dos sólidos.

Dentro das limitações inerentes ao envolvimento com estruturas biológicas, algumas sugestões e ou inferências podem ser feitas, havendo ainda a necessidade de se pesquisar com maior profundidade e mesmo buscar elucidar questões referentes à adesão de C. albicans a superfícies acrílicas em trabalhos futuros. 


\section{CONCLUSÕES}

Analisando os resultados obtidos no presente trabalho é possível concluir que após a simulação de 30 ciclos de desinfecção química da resina acrílica termopolimerizável:

- A imersão da resina acrílica termopolimerizável em soluções desinfetantes, promove alterações nos valores de hidrofobicidade superficial. Sendo que os valores de ângulo de contato reportados foram estatisticamente significantes a partir do 1 ciclo dos grupos controle e Gluconato de clorexidina 4\% e a partir de 7 ciclos no grupo Hipoclorito de sódio.

- A formação da película adquirida salivar promove uma diminuição nos valores de hidrofobicidade superficial da resina acrílica termopolimerizável. Quando comparados aos achados prévios à formação de película adquirida salivar, os valores de ângulo de contato foram estatisticamente significantes em todos os períodos do grupo Hipoclorito de sódio 1\%, nos períodos 1, 7, 15 ciclos do grupo controle e em todos os períodos do grupo Gluconato de clorexidina 4\%, exceto para o período 30 ciclos.

- A imersão da resina acrílica termopolimerizável em soluções desinfetantes, promove uma diminuição na adesão de C. albicans, sendo que os valores foram estatisticamente significantes exclusivamente nos ciclos 15 e 30 do grupo Gluconato de clorexidina 4\% e 30 ciclos do Hipoclorito de sódio 1\%.

- A formação da película adquirida salivar diminui a adesão de C. albicans a acrílico termopolimerizável. Quando comparados aos achados prévios à formação de película adquirida salivar, os valores adesão de C. albicans foram estatisticamente significantes em todos os grupos no 1 ciclo e nos ciclos 15 e 30 dos grupos controle e Hipoclorito de sódio 1\%. 
- Não foi observada correlação entre as variáveis hidrofobicidade superficial e adesão de C. albicans a resina acrílica termopolimerizável nos grupos testados, exceto para os grupos controle e Hipoclorito de sódio $1 \%$ prévio a formação de película adquirida salivar. 


\section{REFERÊNCIAS}

Ábalos C. Ahesión bacteriana a biomateriales. Av Odontoestomatol; 2005. p. 347-53.

Abelson DC. Denture plaque and denture cleansers: review of the literature. Gerodontics. 1985;1(5):202-6.

Absolom DR, Lamberti FV, Policova Z, Zingg W, van Oss CJ, Neumann AW. Surface thermodynamics of bacterial adhesion. Appl Environ Microbiol. 1983;46(1):90-7.

Absolom DR, Zingg W, Neumann AW. Protein adsorption to polymer particles: role of surface properties. J Biomed Mater Res. 1987;21(2):161-71.

Aguirre JM, Verdugo F, Zamacona JM, Quindos G, Ponton J. Cytological changes in oral mucosa in denture stomatitis. Gerodontology. 1996;13(1):63-7.

Al-Hashimi I, Levine MJ. Characterization of in vivo salivary-derived enamel pellicle. Arch Oral Biol. 1989;34(4):289-95.

Ambjornsen E, Rise J. The effect of verbal information and demonstration on denture hygiene in elderly people. Acta Odontol Scand. 1985;43(1):19-24.

Arendorf TM, Walker DM. Oral candidal populations in health and disease. Br Dent J. 1979;147(10):267-72.

Arendorf TM, Walker DM. The prevalence and intra-oral distribution of Candida albicans in man. Arch Oral Biol. 1980;25(1):1-10. 
Arendorf TM, Walker DM. Denture stomatitis: a review. J Oral Rehabil. 1987;14(3):21727.

Asad T, Watkinson AC, Huggett R. The effect of disinfection procedures on flexural properties of denture base acrylic resins. J Prosthet Dent. 1992;68(1):191-5.

Athanassiadis B, Abbott PV, Walsh LJ. The use of calcium hydroxide, antibiotics and biocides as antimicrobial medicaments in endodontics. Aust Dent J. 2007;52(1 Suppl):S64-82.

Axell T, Samaranayake LP, Reichart PA, Olsen I. A proposal for reclassification of oral candidosis. Oral Surg Oral Med Oral Pathol Oral Radiol Endod. 1997;84(2):111-2.

Baier RE, Glantz PO. Characterization of oral in vivo films formed on different types of solid surfaces. Acta Odontol Scand. 1978;36(5):289-301.

Barbeau J, Seguin J, Goulet JP, de Koninck L, Avon SL, Lalonde B, et al. Reassessing the presence of Candida albicans in denture-related stomatitis. Oral Surg Oral Med Oral Pathol Oral Radiol Endod. 2003;95(1):51-9.

Barnabe W, de Mendonca Neto T, Pimenta FC, Pegoraro LF, Scolaro JM. Efficacy of sodium hypochlorite and coconut soap used as disinfecting agents in the reduction of denture stomatitis, Streptococcus mutans and Candida albicans. J Oral Rehabil. 2004;31(5):453-9.

Barroeta AU, Méndez GRd, Lelis AB. Acción de agentes químicos en la eliminación de Cándida albicans sobre prótesis dentales. Acta Odontol venez. 2007;45(2):172-7.

Basson NJ, Quick AN, Thomas CJ. Household products as sanitising agents in denture cleansing. J Dent Assoc S Afr. 1992;47(10):437-9. 
Baysan A, Whiley R, Wright PS. Use of microwave energy to disinfect a long-term soft lining material contaminated with Candida albicans or Staphylococcus aureus. J Prosthet Dent. 1998;79(4):454-8.

Beausejour A, Grenier D, Goulet JP, Deslauriers N. Proteolytic activation of the interleukin-1beta precursor by Candida albicans. Infect Immun. 1998;66(2):676-81.

Bell JA, Brockmann SL, Feil P, Sackuvich DA. The effectiveness of two disinfectants on denture base acrylic resin with an organic load. J Prosthet Dent. 1989;61(5):580-3.

Bergendal T. Status and treatment of denture stomatitis patients: a 1-year follow-up study. Scand J Dent Res. 1982;90(3):227-38.

Bergendal T, Isacsson G. A combined clinical, mycological and histological study of denture stomatitis. Acta Odontol Scand. 1983;41(1):33-44.

Birman EG. Candida e Candidoses. In: Tommasi MH, editor. Diagnóstico em Patologia Bucal. 3 ed. São Paulo: Pancast; 2002. p. 198-9.

Block S. Disinfection, sterilization, and preservation. 4ed ed. Philadelphia: Lea \& Febiger; 1991.

Bosch JA, Turkenburg M, Nazmi K, Veerman EC, de Geus EJ, Nieuw Amerongen AV. Stress as a determinant of saliva-mediated adherence and coadherence of oral and nonoral microorganisms. Psychosom Med. 2003;65(4):604-12.

Budtz-Jorgensen E. Denture stomatitis. 3. Histopathology of trauma- and candidainduced inflammatory lesions of the palatal mucosa. Acta Odontol Scand. 1970;28(5):551-79. 
Budtz-Jorgensen E. The significance of Candida albicans in denture stomatitis. Scand J Dent Res. 1974;82(2):151-90.

Budtz-Jorgensen E. Clinical aspects of Candida infection in denture wearers. J Am Dent Assoc. 1978;96(3):474-9.

Budtz-Jorgensen E. Materials and methods for cleaning dentures. J Prosthet Dent. 1979;42(6):619-23.

Budtz-Jorgensen E, Mojon P, Rentsch A, Deslauriers N. Effects of an oral health program on the occurrence of oral candidosis in a long-term care facility. Community Dent Oral Epidemiol. 2000;28(2):141-9.

Budtz-Jorgensen E, Stenderup A, Grabowski M. An epidemiologic study of yeasts in elderly denture wearers. Community Dent Oral Epidemiol. 1975;3(3):115-9.

Buergers R, Rosentritt M, Schneider-Brachert W, Behr M, Handel G, Hahnel S. Efficacy of denture disinfection methods in controlling Candida albicans colonization in vitro. Acta Odontol Scand. 2008;66(3):174-80.

Bunetel L, Bonnaure-Mallet M. Oral pathoses caused by Candida albicans during chemotherapy: update on development mechanisms. Oral Surg Oral Med Oral Pathol Oral Radiol Endod. 1996;82(2):161-5.

Busscher H, Weerkamp A. Specific and non-specific interactions in bacterial adhesion to solid substrata. FEMS Microbiol reviews. 1987;46:165-73.

Busscher HJ, Bos R, van der Mei HC. Initial microbial adhesion is a determinant for the strength of biofilm adhesion. FEMS Microbiol Lett. 1995;128(3):229-34. 
Busscher HJ, Cowan MM, van der Mei HC. On the relative importance of specific and non-specific approaches to oral microbial adhesion. FEMS Microbiol Rev. 1992;8(34):199-209.

Calderone R. The INT1 of Candida albicans. Trends Microbiol. 1998;6(8):300-1; discussion 2-3.

Calderone RA, Braun PC. Adherence and receptor relationships of Candida albicans. Microbiol Rev. 1991;55(1):1-20.

Cannon RD, Chaffin WL. Oral colonization by Candida albicans. Crit Rev Oral Biol Med. 1999;10(3):359-83.

Cannon RD, Chaffin WL. Colonization is a crucial factor in oral candidiasis. J Dent Educ. 2001;65(8):785-7.

Ceballos A, Gonzalez-Moles M, Urquia M. [Denture stomatitis. Its relation to candida albicans]. Av Odontoestomatol. 1990;6(2):151-4.

Chan EC, Iugovaz I, Siboo R, Bilyk M, Barolet R, Amsel R, et al. Comparison of two popular methods for removal and killing of bacteria from dentures. J Can Dent Assoc. 1991;57(12):937-9.

Chau VB, Saunders TR, Pimsler M, Elfring DR. In-depth disinfection of acrylic resins. J Prosthet Dent. 1995;74(3):309-13.

Combe EC, Owen BA, Hodges JS. A protocol for determining the surface free energy of dental materials. Dent Mater. 2004;20(3):262-8.

Cottone JA, Molinari JA. Selection for dental practice of chemical disinfectants and sterilants for hepatitis and AIDS. Aust Dent J. 1987;32(5):368-74. 
Crockett DN, O'Grady JF, Reade PC. Candida species and Candida albicans morphotypes in erythematous candidiasis. Oral Surg Oral Med Oral Pathol. 1992;73(5):559-63.

Cross LJ, Bagg J, Wray D, Aitchison T. A comparison of fluconazole and itraconazole in the management of denture stomatitis: a pilot study. J Dent. 1998;26(8):657-64.

Cumming CG, Wight C, Blackwell CL, Wray D. Denture stomatitis in the elderly. Oral Microbiol Immunol. 1990;5(2):82-5.

da Silva FC, Kimpara ET, Mancini MN, Balducci I, Jorge AO, Koga-Ito CY. Effectiveness of six different disinfectants on removing five microbial species and effects on the topographic characteristics of acrylic resin. J Prosthodont. 2008;17(8):627-33.

Darvell BW. Surfaces. In: Darvell BW, editor. Materials Science for Dentistry. 6th ed. Hong Kong: Woodhead.

Davenport JC. The oral distribution of candida in denture stomatitis. Br Dent J. 1970;129(4):151-6.

de Jong HP, van Pelt AW, Busscher HJ, Arends J. The effect of topical fluoride applications on the surface free energy of human enamel--an in vitro study. J Dent Res. 1984;63(5):635-41.

DePaola LG, Minah GE, Elias SA. Evaluation of agents to reduce microbial growth on dental prostheses of myelosuppressed cancer patients. Clin Prev Dent. 1984;6(2):9-12.

Dills SS, Olshan AM, Goldner S, Brogdon C. Comparison of the antimicrobial capability of an abrasive paste and chemical-soak denture cleaners. J Prosthet Dent. 1988;60(4):467-70. 
Dodds MW, Johnson DA, Yeh CK. Health benefits of saliva: a review. J Dent. 2005;33(3):223-33.

Douglas LJ. Adhesion of pathogenic Candida species to host surfaces. Microbiol Sci. 1985;2(8):243-7.

Edgerton M, Levine MJ. Characterization of acquired denture pellicle from healthy and stomatitis patients. J Prosthet Dent. 1992;68(4):683-91.

Edgerton M, Lo SE, Scannapieco FA. Experimental salivary pellicles formed on titanium surfaces mediate adhesion of streptococci. Int $\mathrm{J}$ Oral Maxillofac Implants. 1996;11(4):443-9.

Edgerton M, Scannapieco FA, Reddy MS, Levine MJ. Human submandibular-sublingual saliva promotes adhesion of Candida albicans to polymethylmethacrylate. Infect Immun. 1993;61(6):2644-52.

Elguezabal N, Maza JL, Ponton J. Inhibition of adherence of Candida albicans and Candida dubliniensis to a resin composite restorative dental material by salivary secretory IgA and monoclonal antibodies. Oral Dis. 2004;10(2):81-6.

Ellingsen JE, Rolla G. Dental plaque inhibition by a combination of triclosan and polydimethylsiloxane (silicone oil). Scand J Dent Res. 1994;102(1):26-9.

Estrela C, Estrela CR, Barbin EL, Spano JC, Marchesan MA, Pecora JD. Mechanism of action of sodium hypochlorite. Braz Dent J. 2002;13(2):113-7.

Fine DH, Wilton JM, Caravana C. In vitro sorption of albumin, immunoglobulin G, and lysozyme to enamel and cementum from human teeth. Infect Immun. 1984;44(2):332-8. 
Fotos PG, Hellstein JW. Candida and candidosis. Epidemiology, diagnosis and therapeutic management. Dent Clin North Am. 1992;36(4):857-78.

Frank RM, Steuer P. Transmission electron microscopy of plaque accumulations in denture stomatitis. J Prosthet Dent. 1985;53(1):115-24.

Fridkin SK, Jarvis WR. Epidemiology of nosocomial fungal infections. Clin Microbiol Rev. 1996;9(4):499-511.

Fukuzaki S. Mechanisms of actions of sodium hypochlorite in cleaning and disinfection processes. Biocontrol Sci. 2006;11(4):147-57.

Ghalichebaf M, Graser GN, Zander HA. The efficacy of denture-cleansing agents. J Prosthet Dent. 1982;48(5):515-20.

Glantz P. On Wettability and Adhesiveness. Odont Revy. 1969;20(Suppl 17):5-124.

Glass RT, Bullard JW, Conrad RS, Blewett EL. Evaluation of the sanitization effectiveness of a denture-cleaning product on dentures contaminated with known microbial flora. An in vitro study. Quintessence Int. 2004;35(3):194-9.

Gomes BP, Berber VB, Montagner F, Sena NT, Zaia AA, Ferraz CC, et al. Residual effects and surface alterations in disinfected gutta-percha and Resilon cones. J Endod. 2007;33(8):948-51.

Gomes BP, Souza SF, Ferraz CC, Teixeira FB, Zaia AA, Valdrighi L, et al. Effectiveness of $2 \%$ chlorhexidine gel and calcium hydroxide against Enterococcus faecalis in bovine root dentine in vitro. Int Endod J. 2003;36(4):267-75. 
Gornitsky M, Paradis II, Landaverde G, Malo AM, Velly AM. A clinical and microbiological evaluation of denture cleansers for geriatric patients in long-term care institutions. J Can Dent Assoc. 2002;68(1):39-45.

Greenstein G, Berman C, Jaffin R. Chlorhexidine. An adjunct to periodontal therapy. J Periodontol. 1986;57(6):370-7.

Guggenheimer J, Moore PA, Rossie K, Myers D, Mongelluzzo MB, Block HM, et al. Insulin-dependent diabetes mellitus and oral soft tissue pathologies: II. Prevalence and characteristics of Candida and Candidal lesions. Oral Surg Oral Med Oral Pathol Oral Radiol Endod. 2000;89(5):570-6.

Hauman $\mathrm{CH}$, Love RM. Biocompatibility of dental materials used in contemporary endodontic therapy: a review. Part 1. Intracanal drugs and substances. Int Endod J. 2003;36(2):75-85.

Hoad-Reddick G, Grant AA, Griffiths CS. Investigation into the cleanliness of dentures in an elderly population. J Prosthet Dent. 1990;64(1):48-52.

Iacopino AM, Wathen WF. Oral candidal infection and denture stomatitis: a comprehensive review. J Am Dent Assoc. 1992;123(1):46-51.

Jagger DC, Harrison A. Denture cleansing--the best approach. $\mathrm{Br}$ Dent $\mathrm{J}$. 1995;178(11):413-7.

Jeganathan S, Payne JA, Thean HP. Denture stomatitis in an elderly edentulous Asian population. J Oral Rehabil. 1997;24(6):468-72.

Jennings KJ, MacDonald DG. Histological, microbiological and haematological investigations in denture-induced stomatitis. J Dent. 1990;18(2):102-6. 
Jensen JL, Lamkin MS, Oppenheim FG. Adsorption of human salivary proteins to hydroxyapatite: a comparison between whole saliva and glandular salivary secretions. $\mathrm{J}$ Dent Res. 1992;71(9):1569-76.

Jin Y, Samaranayake LP, Samaranayake Y, Yip HK. Biofilm formation of Candida albicans is variably affected by saliva and dietary sugars. Arch Oral Biol. 2004;49(10):789-98.

Johansson I, Bratt P, Hay DI, Schluckebier S, Stromberg N. Adhesion of Candida albicans, but not Candida krusei, to salivary statherin and mimicking host molecules. Oral Microbiol Immunol. 2000;15(2):112-8.

Klotz SA, Drutz DJ, Zajic JE. Factors governing adherence of Candida species to plastic surfaces. Infect Immun. 1985;50(1):97-101.

Kolenbrander PE, London J. Adhere today, here tomorrow: oral bacterial adherence. J Bacteriol. 1993;175(11):3247-52.

Kraus FW, Orstavik D, Hurst DC, Cook CH. The acquired pellicle: variability and subject-dependence of specific proteins. J Oral Pathol. 1973;2(3):165-73.

Kreher JM, Graser GN, Handelman SL, Eisenberg AD. Oral yeasts, mucosal health, and drug use in an elderly denture-wearing population. Spec Care Dentist. 1991;11(6):222-6.

Kuc IM, Samaranayake LP, van Heyst EN. Oral health and microflora in an institutionalised elderly population in Canada. Int Dent J. 1999;49(1):33-40.

Kulak Y, Arikan A, Delibalta N. Comparison of three different treatment methods for generalized denture stomatitis. J Prosthet Dent. 1994;72(3):283-8. 
Kulak-Ozkan Y, Kazazoglu E, Arikan A. Oral hygiene habits, denture cleanliness, presence of yeasts and stomatitis in elderly people. J Oral Rehabil. 2002;29(3):300-4.

Lamb DJ, Martin MV. An in vitro and in vivo study of the effect of incorporation of chlorhexidine into autopolymerizing acrylic resin plates upon the growth of Candida albicans. Biomaterials. 1983;4(3):205-9.

Lamfon H, Al-Karaawi Z, McCullough M, Porter SR, Pratten J. Composition of in vitro denture plaque biofilms and susceptibility to antifungals. FEMS Microbiol Lett. $2005 ; 242(2): 345-51$.

Lee RG, Adamson C, Kim SW. Competitive adsorption of plasma proteins onto polymer surfaces. Thromb Res. 1974;4(3):485-90.

Lin JJ, Cameron SM, Runyan DA, Craft DW. Disinfection of denture base acrylic resin. J Prosthet Dent. 1999;81(2):202-6.

Lockhart SR, Joly S, Vargas K, Swails-Wenger J, Enger L, Soll DR. Natural defenses against Candida colonization breakdown in the oral cavities of the elderly. J Dent Res. 1999;78(4):857-68.

Lombardi T, Budtz-Jorgensen E. Treatment of denture-induced stomatitis: a review. Eur J Prosthodont Restor Dent. 1993;2(1):17-22.

Lynch DP. Oral candidiasis. History, classification, and clinical presentation. Oral Surg Oral Med Oral Pathol. 1994;78(2):189-93.

Ma T, Johnson GH, Gordon GE. Effects of chemical disinfectants on the surface characteristics and color of denture resins. J Prosthet Dent. 1997;77(2):197-204. 
MacNeill S, Rindler E, Walker A, Brown AR, Cobb CM. Effects of tetracycline hydrochloride and chlorhexidine gluconate on Candida albicans. An in vitro study. J Clin Periodontol. 1997;24(10):753-60.

Mahonen K, Virtanen K, Larmas M. The effect of prosthesis disinfection on salivary microbial levels. J Oral Rehabil. 1998;25(4):304-10.

Maza JL, Elguezabal N, Prado C, Ellacuria J, Soler I, Ponton J. Candida albicans adherence to resin-composite restorative dental material: influence of whole human saliva. Oral Surg Oral Med Oral Pathol Oral Radiol Endod. 2002;94(5):589-92.

McCourtie J, Douglas LJ. Relationship between cell surface composition of Candida albicans and adherence to acrylic after growth on different carbon sources. Infect Immun. 1981;32(3):1234-41.

McCourtie J, Douglas LJ. Relationship between cell surface composition, adherence, and virulence of Candida albicans. Infect Immun. 1984;45(1):6-12.

McCourtie J, MacFarlane TW, Samaranayake LP. Effect of chlorhexidine gluconate on the adherence of Candida species to denture acrylic. J Med Microbiol. 1985;20(1):97104.

McGowan MJ, Shimoda LM, Woolsey GD. Effects of sodium hypochlorite on denture base metals during immersion for short-term sterilization. $\mathrm{J}$ Prosthet Dent. 1988;60(2):212-8.

McMullan-Vogel CG, Jude HD, Ollert MW, Vogel CW. Serotype distribution and secretory acid proteinase activity of Candida albicans isolated from the oral mucosa of patients with denture stomatitis. Oral Microbiol Immunol. 1999;14(3):183-9. 
Millsap KW, Bos R, van der Mei HC, Busscher HJ. Adhesion and surface-aggregation of Candida albicans from saliva on acrylic surfaces with adhering bacteria as studied in a parallel plate flow chamber. Antonie Van Leeuwenhoek. 1999;75(4):351-9.

Minagi S, Miyake Y, Inagaki K, Tsuru H, Suginaka H. Hydrophobic interaction in Candida albicans and Candida tropicalis adherence to various denture base resin materials. Infect Immun. 1985;47(1):11-4.

Minagi S, Tsunoda T, Yoshida K, Tsuru H. Objective testing of the efficiency of denturecleansing agents. J Prosthet Dent. 1987;58(5):595-8.

Miyake Y, Fujita Y, Minagi S, Suginaka H. Surface hydrophobicity and adherence of Candida to acrylic surfaces. Microbios. 1986;46(186):7-14.

Mohammadi Z. Sodium hypochlorite in endodontics: an update review. Int Dent J. 2008;58(6):329-41.

Mohammadi Z, Abbott PV. The properties and applications of chlorhexidine in endodontics. Int Endod J. 2009;42(4):288-302.

Molinari JA, Runnells RR. Role of disinfectants in infection control. Dent Clin North Am. 1991;35(2):323-37.

Moore TC, Smith DE, Kenny GE. Sanitization of dentures by several denture hygiene methods. J Prosthet Dent. 1984;52(2):158-63.

Moura JS, da Silva WJ, Pereira T, Del Bel Cury AA, Rodrigues Garcia RC. Influence of acrylic resin polymerization methods and saliva on the adherence of four Candida species. J Prosthet Dent. 2006;96(3):205-11. 
Murtomaa H, Meurman JH. Mechanical aids in the prevention of dental diseases in the elderly. Int Dent J. 1992;42(5):365-72.

Nakamoto K, Tamamoto M, Hamada T. Evaluation of denture cleansers with and without enzymes against Candida albicans. J Prosthet Dent. 1991;66(6):792-5.

Neumann, Good R, Hoppe C, Sejpal M. An equation-of-stateapproach to determine surface tensions of low-energy solids from contact angles. Journal of Colloid and Interface Science. 1974;49:291-304.

Newman F, Beeley JA, MacFarlane TW. Adherence of oral microorganisms to human parotid salivary proteins. Electrophoresis. 1996;17(1):266-70.

Newton A. Denture sore mouth: a possible aetiology. Br Dent J. 1962;112:357.

Nikawa H, Hamada T. Binding of salivary or serum proteins to Candida albicans in vitro. Arch Oral Biol. 1990;35(7):571-3.

Nikawa H, Hamada T, Yamamoto T. Denture plaque--past and recent concerns. J Dent. 1998;26(4):299-304.

Nikawa H, Hamada T, Yamashiro H, Kumagai H. A review of in vitro and in vivo methods to evaluate the efficacy of denture cleansers. Int J Prosthodont. 1999;12(2):1539.

Nikawa H, Hayashi S, Nikawa Y, Hamada T, Samaranayake LP. Interactions between denture lining material, protein pellicles and Candida albicans. Arch Oral Biol. 1993;38(7):631-4.

Nikawa H, Iwanaga H, Kameda M, Hamada T. In vitro evaluation of Candida albicans adherence to soft denture-lining materials. J Prosthet Dent. 1992a;68(5):804-8. 
Nikawa H, Jin C, Hamada T, Makihira S, Kumagai H, Murata H. Interactions between thermal cycled resilient denture lining materials, salivary and serum pellicles and Candida albicans in vitro. Part II. Effects on fungal colonization. J Oral Rehabil. 2000;27(2):124-30.

Nikawa H, Sadamori S, Hamada T, Okuda K. Factors involved in the adherence of Candida albicans and Candida tropicalis to protein-adsorbed surfaces. An in vitro study using immobilized protein. Mycopathologia. 1992b;118(3):139-45.

O'Sullivan JM, Cannon RD, Sullivan PA, Jenkinson HF. Identification of salivary basic proline-rich proteins as receptors for Candida albicans adhesion. Microbiology. 1997;143 ( Pt 2):341-8.

Odman PA. The effectiveness of an enzyme-containing denture cleanser. Quintessence Int. 1992;23(3):187-90.

Ohman SC, Osterberg T, Dahlen G, Landahl S. The prevalence of Staphylococcus aureus, Enterobacteriaceae species, and Candida species and their relation to oral mucosal lesions in a group of 79-year-olds in Goteborg. Acta Odontol Scand. 1995;53(1):49-54.

Olsen I. Denture stomatitis. Occurrence and distribution of fungi. Acta Odontol Scand. 1974;32(5):329-33.

Olsen I. Oral adhesion of yeasts. Acta Odontol Scand. 1990;48(1):45-53.

Olsson J, Glantz PO, Krasse B. Surface potential and adherence of oral streptococci to solid surfaces. Scand J Dent Res. 1976;84(4):240-2. 
Pavarina AC, Pizzolitto AC, Machado AL, Vergani CE, Giampaolo ET. An infection control protocol: effectiveness of immersion solutions to reduce the microbial growth on dental prostheses. J Oral Rehabil. 2003;30(5):532-6.

Pereira-Cenci T, Cury AA, Cenci MS, Rodrigues-Garcia RC. In vitro Candida colonization on acrylic resins and denture liners: influence of surface free energy, roughness, saliva, and adhering bacteria. Int J Prosthodont. 2007;20(3):308-10.

Pratt-Terpstra IH, Mulder J, Weerkamp AH, Feijen J, Busscher HJ. Secretory IgA adsorption and oral streptococcal adhesion to human enamel and artificial solid substrata with various surface free energies. J Biomater Sci Polym Ed. 1991;2(4):239-53.

Pratt-Terpstra IH, Weerkamp AH, Busscher HJ. The effects of pellicle formation on streptococcal adhesion to human enamel and artificial substrata with various surface freeenergies. J Dent Res. 1989;68(3):463-7.

Quirynen M, Bollen CM. The influence of surface roughness and surface-free energy on supra- and subgingival plaque formation in man. A review of the literature. J Clin Periodontol. 1995;22(1):1-14.

Radford DR, Challacombe SJ, Walter JD. Denture plaque and adherence of Candida albicans to denture-base materials in vivo and in vitro. Crit Rev Oral Biol Med. 1999;10(1):99-116.

Radford DR, Sweet SP, Challacombe SJ, Walter JD. Adherence of Candida albicans to denture-base materials with different surface finishes. J Dent. 1998;26(7):577-83.

Rogers TJ, Balish E. Immunity to Candida albicans. Microbiol Rev. 1980;44(4):660-82. 
Rolla G, Ciardi JE, Bowen WH. Identification of IgA, IgG, lysozyme, albumin, alphaamylase and glucosyltransferase in the protein layer adsorbed to hydroxyapatite from whole saliva. Scand J Dent Res. 1983;91(3):186-90.

Rosenberg M, Kjelleberg S. Hydrophobic interactions: Role in Bacterial adhesions. Microbiol Ecol. 1986;9:353-93.

Ruan MS, Di Paola C, Mandel ID. Quantitative immunochemistry of salivary proteins adsorbed in vitro to enamel and cementum from caries-resistant and caries-susceptible human adults. Arch Oral Biol. 1986;31(9):597-601.

Rudd RW, Senia ES, McCleskey FK, Adams ED, Jr. Sterilization of complete dentures with sodium hypochlorite. J Prosthet Dent. 1984;51(3):318-21.

Rutala WA, Weber DJ. Uses of inorganic hypochlorite (bleach) in health-care facilities. Clin Microbiol Rev. 1997;10(4):597-610.

Samaranayake LP, MacFarlane TW. An in-vitro study of the adherence of Candida albicans to acrylic surfaces. Arch Oral Biol. 1980;25(8-9):603-9.

Samaranayake LP, Nair RG. Oral Candida infections--a review. Indian J Dent Res. $1995 ; 6(3): 69-82$.

Samaranayake YH, Wu PC, Samaranayake LP, So M. Relationship between the cell surface hydrophobicity and adherence of Candida krusei and Candida albicans to epithelial and denture acrylic surfaces. Apmis. 1995;103(10):707-13.

San Millan R, Elguezabal N, Regulez P, Moragues MD, Quindos G, Ponton J. Effect of salivary secretory $\operatorname{IgA}$ on the adhesion of Candida albicans to polystyrene. Microbiology. 2000;146 ( Pt 9):2105-12. 
San Millan R, Ezkurra PA, Quindos G, Robert R, Senet JM, Ponton J. Effect of monoclonal antibodies directed against Candida albicans cell wall antigens on the adhesion of the fungus to polystyrene. Microbiology. 1996;142 ( Pt 8):2271-7.

Santarpia RP, 3rd, Pollock JJ, Renner RP, Spiechowicz E. An in vivo replica method for the site-specific detection of Candida albicans on the denture surface in denture stomatitis patients: correlation with clinical disease. J Prosthet Dent. 1990;63(4):437-43.

Saunders TR, Guillory VL, Gregoire ST, Pimsler M, Mitchell MS. The effect of bioburden on in-depth disinfection of denture base acrylic resin. J Calif Dent Assoc. 1998;26(11):846-50.

Schou L, Wight C, Cumming C. Oral hygiene habits, denture plaque, presence of yeasts and stomatitis in institutionalised elderly in Lothian, Scotland. Community Dent Oral Epidemiol. 1987;15(2):85-9.

Segal E, Lehrman O, Dayan D. Adherence in vitro of various Candida species to acrylic surfaces. Oral Surg Oral Med Oral Pathol. 1988;66(6):670-3.

Sesma N, KS T, DC L, RG J, N AJ. Eficiência de Métodos Caseiros de Higienização e Limpeza de Próteses Parciais Removíveis. Rev Assoc Paul Cir Dent. 1999;53(6):463-8.

Sipahi C, Anil N, Bayramli E. The effect of acquired salivary pellicle on the surface free energy and wettability of different denture base materials. J Dent. 2001;29(3):197-204.

Spiechowicz E, Santarpia RP, 3rd, Pollock JJ, Renner RP. In vitro study on the inhibiting effect of different agents on the growth of Candida albicans on acrylic resin surfaces. Quintessence Int. 1990;21(1):35-40.

Sullivan D, Coleman D. Candida dubliniensis: characteristics and identification. J Clin Microbiol. 1998;36(2):329-34. 
Sumi Y, Kagami H, Ohtsuka Y, Kakinoki Y, Haruguchi Y, Miyamoto H. High correlation between the bacterial species in denture plaque and pharyngeal microflora. Gerodontology. 2003;20(2):84-7.

Tanida T, Ueta E, Tobiume A, Hamada T, Rao F, Osaki T. Influence of aging on candidal growth and adhesion regulatory agents in saliva. J Oral Pathol Med. 2001;30(6):328-35.

Tari BF, Nalbant D, Dogruman Al F, Kustimur S. Surface roughness and adherence of Candida albicans on soft lining materials as influenced by accelerated aging. J Contemp Dent Pract. 2007;8(5):18-25.

Test ST, Lampert MB, Ossanna PJ, Thoene JG, Weiss SJ. Generation of nitrogenchlorine oxidants by human phagocytes. J Clin Invest. 1984;74(4):1341-9.

Teughels W, Van Assche N, Sliepen I, Quirynen M. Effect of material characteristics and/or surface topography on biofilm development. Clin Oral Implants Res. 2006;17 Suppl 2:68-81.

Ureña JL. Caracteristicas gererales de los hongos patógenos humanos. In: Ureña JL, editor. Microbiologia Oral. 1 ed. Madrid: Mc Graw Hill; 1995. p. 362-75.

Vasilas A, Molina L, Hoffman M, Haidaris CG. The influence of morphological variation on Candida albicans adhesion to denture acrylic in vitro. Arch Oral Biol. 1992;37(8):61322.

Veerman EC, van den Keybus PA, Vissink A, Nieuw Amerongen AV. Human glandular salivas: their separate collection and analysis. Eur J Oral Sci. 1996;104(4 ( Pt 1)):346-52.

Waters MG, Williams DW, Jagger RG, Lewis MA. Adherence of Candida albicans to experimental denture soft lining materials. J Prosthet Dent. 1997;77(3):306-12. 
Webb BC, Thomas CJ, Willcox MD, Harty DW, Knox KW. Candida-associated denture stomatitis. Aetiology and management: a review. Part 2. Oral diseases caused by Candida species. Aust Dent J. 1998;43(3):160-6.

Webb BC, Willcox MD, Thomas CJ, Harty DW, Knox KW. The effect of sodium hypochlorite on potential pathogenic traits of Candida albicans and other Candida species. Oral Microbiol Immunol. 1995;10(6):334-41.

Williams DW, Potts AJ, Wilson MJ, Matthews JB, Lewis MA. Characterisation of the inflammatory cell infiltrate in chronic hyperplastic candidosis of the oral mucosa. J Oral Pathol Med. 1997;26(2):83-9.

Yildirim MS, Hasanreisoglu U, Hasirci N, Sultan N. Adherence of Candida albicans to glow-discharge modified acrylic denture base polymers. J Oral Rehabil. 2005;32(7):51825.

Yilmaz H, Aydin C, Bal BT, Ozcelik B. Effects of disinfectants on resilient denturelining materials contaminated with Staphylococcus aureus, Streptococcus sobrinus, and Candida albicans. Quintessence Int. 2005;36(5):373-81.

Zehnder M. Root canal irrigants. J Endod. 2006;32(5):389-98. 